\title{
FOUNDATIONS OF TECHNICAL ANALYSIS: COMPUTATIONAL ALGORITHMS, STATISTICAL INFERENCE, AND EMPIRICAL IMPLEMENTATION
}

\author{
Andrew W. Lo \\ Harry Mamaysky \\ Jiang Wang \\ Working Paper 7613 \\ http://www.nber.org/papers/w7613 \\ NATIONAL BUREAU OF ECONOMIC RESEARCH \\ 1050 Massachusetts Avenue \\ Cambridge, MA 02138 \\ March 2000
}

This research was partially supported by the MIT laboratory for Financial Engineering, Merrill Lynch, and the National Science Foundation (Grant No. SBR-9709976). We thank Ralph Acampora, Franklin Allen, Susan Berger, Mike Epstein, Narasimhan Jegadeesh, Ed Kao, Doug Sanzone, Jeff Simonoff, Tom Stoker, and seminar participants at the Federal Reserve Bank of New York, NYU, and conference participants at the Columbia-JAFEE conference, the 1999 Joint Statistical Meetings, RISK 99, the 1999 Annual Meeting of the Society for Computational Economics, and the 2000 Annual Meeting of the American Finance Association for valuable comments and discussion. The views expressed herein are those of the authors and are not necessarily those of the National Bureau of Economic Research.

(C) 2000 by Andrew W. Lo, Harry Mamaysky, and Jiang Wang. All rights reserved. Short sections of text, not to exceed two paragraphs, may be quoted without explicit permission provided that full credit, including (C) notice, is given to the source. 
Foundations of Technical Analysis: Computational Algorithms, Statistical Inference, and Empirical Implementation Andrew W. Lo, Harry Mamaysky, and Jiang Wang NBER Working Paper No. 7613

March 2000

\begin{abstract}
Technical analysis, also known as "charting," has been part of financial practice for many decades, but this discipline has not received the same level of academic scrutiny and acceptance as more traditional approaches such as fundamental analysis. One of the main obstacles is the highly subjective nature of technical analysis-the presence of geometric shapes in historical price charts is often in the eyes of the beholder. In this paper, we propose a systematic and automatic approach to technical pattern recognition using nonparametric kernel regression, and apply this method to a large number of U.S. stocks from 1962 to 1996 to evaluate the effectiveness to technical analysis. By comparing the unconditional empirical distribution of daily stock returns to the conditional distribution-conditioned on specific technical indicators such as head-and-shoulders or doublebottoms-we find that over the 31-year sample period, several technical indicators do provide incremental information and may have some practical value.
\end{abstract}

Andrew W. Lo

Sloan School of Management

MIT

50 Memorial Drive, E52-432

Cambridge, MA 02142

and NBER

alo@mit.edu

Jiang Wang

Sloan School of Management

MIT

50 Memorial Drive, E52-435

Cambridge, MA 02142

and NBER

wangj@mit.edu
Harry Mamaysky

Sloan School of Management

MIT

50 Memorial Drive, E52-458

Cambridge, MA 02142

harrym@mit.edu 
One of the greatest gulfs between academic finance and industry practice is the separation that exists between technical analysts and their academic critics. In contrast to fundamental analysis, which was quick to be adopted by the scholars of modern quantitative finance, technical analysis has been an orphan from the very start. It has been argued that the difference between fundamental analysis and technical analysis is not unlike the difference between astronomy and astrology. Among some circles, technical analysis is known as "voodoo finance." And in his influential book A Random Walk Down Wall Street, Burton Malkiel (1996) concludes that "[u]nder scientific scrutiny, chart-reading must share a pedestal with alchemy."

However, several academic studies suggest that despite its jargon and methods, technical analysis may well be an effective means for extracting useful information from market prices. For example, in rejecting the Random Walk Hypothesis for weekly US stock indexes, Lo and MacKinlay $(1988,1999)$ have shown that past prices may be used to forecast future returns to some degree, a fact that all technical analysts take for granted. Studies by Tabell and Tabell (1964), Treynor and Ferguson (1985), Brown and Jennings (1989), Jegadeesh and Titman (1993), Blume, Easley, and O'Hara (1994), Chan, Jegadeesh, and Lakonishok (1996), Lo and MacKinlay (1997), Grundy and Martin (1998), and Rouwenhorst (1998) have also provided indirect support for technical analysis, and more direct support has been given by Pruitt and White (1988), Neftci (1991), Brock, Lakonishok, and LeBaron (1992), Neely, Weber, and Dittmar (1997), Neely and Weller (1998), Chang and Osler (1994), Osler and Chang (1995), and Allen and Karjalainen (1999).

One explanation for this state of controversy and confusion is the unique and sometimes impenetrable jargon used by technical analysts, some of which has developed into a standard lexicon that can be translated. But there are many "homegrown" variations, each with its own patois, which can often frustrate the uninitiated. Campbell, Lo, and MacKinlay (1997, pp. 43-44) provide a striking example of the linguistic barriers between technical analysts and academic finance by contrasting this statement:

The presence of clearly identified support and resistance levels, coupled with a one-third retracement parameter when prices lie between them, suggests the 
presence of strong buying and selling opportunities in the near-term.

with this one:

The magnitudes and decay pattern of the first twelve autocorrelations and the statistical significance of the Box-Pierce $Q$-statistic suggest the presence of a high-frequency predictable component in stock returns.

Despite the fact that both statements have the same meaning-that past prices contain information for predicting future returns--most readers find one statement plausible and the other puzzling, or worse, offensive.

These linguistic barriers underscore an important difference between technical analysis and quantitative finance: technical analysis is primarily visual, while quantitative finance is primarily algebraic and numerical. Therefore, technical analysis employs the tools of geometry and pattern recognition, while quantitative finance employs the tools of mathematical analysis and probability and statistics. In the wake of recent breakthroughs in financial engineering, computer technology, and numerical algorithms, it is no wonder that quantitative finance has overtaken technical analysis in popularity-the principles of portfolio optimization are far easier to program into a computer than the basic tenets of technical analysis. Nevertheless, technical analysis has survived through the years, perhaps because its visual mode of analysis is more conducive to human cognition, and because pattern recognition is one of the few repetitive activities for which computers do not have an absolute advantage (yet).

Indeed, it is difficult to dispute the potential value of price/volume charts when confronted with the visual evidence. For example, compare the two hypothetical price charts given in Figure I. Despite the fact that the two price series are identical over the first half of the sample, the volume patterns differ, and this seems to be informative. In particular, the lower chart, which shows high volume accompanying a positive price trend, suggests that there may be more information content in the trend, e.g., broader participation among investors. The fact that the joint distribution of prices and volume contains important information is hardly controversial among academics. Why, then, is the value of a visual depiction of that joint distribution so hotly contested? 
In this paper, we hope to bridge this gulf between technical analysis and quantitative finance by developing a systematic and scientific approach to the practice of technical analysis, and by employing the now-standard methods of empirical analysis to gauge the efficacy of technical indicators over time and across securities. In doing so, our goal is not only to develop a lingua franca with which disciples of both disciplines can engage in productive dialogue, but also to extend the reach of technical analysis by augmenting its tool kit with some modern techniques in pattern recognition.

The general goal of technical analysis is to identify regularities in the time series of prices by extracting nonlinear patterns from noisy data. Implicit in this goal is the recognition that some price movements are significant - they contribute to the formation of a specific pattern-and others are merely random fluctuations to be ignored. In many cases, the human eye can perform this "signal extraction" quickly and accurately, and until recently, computer algorithms could not. However, a class of statistical estimators, called smoothing estimators, is ideally suited to this task because they extract nonlinear relations $\hat{m}(\cdot)$ by "averaging out" the noise. Therefore, we propose using these estimators to mimic, and in some cases, sharpen the skills of a trained technical analyst in identifying certain patterns in historical price series.

In Section I, we provide a brief review of smoothing estimators and describe in detail the specific smoothing estimator we use in our analysis: kernel regression. Our algorithm for automating technical analysis is described in Section II. We apply this algorithm to the daily returns of several hundred U.S. stocks from 1962 to 1996 and report the results in Section III. To check the accuracy of our statistical inferences, we perform several Monte Carlo simulation experiments and the results are given in Section IV. We conclude in Section V.

\section{Smoothing Estimators and Kernel Regression}

The starting point for any study of technical analysis is the recognition that prices evolve in a nonlinear fashion over time and that the nonlinearities contain certain regularities or patterns. To capture such regularities quantitatively, we begin by asserting that prices $\left\{P_{t}\right\}$. 
satisfy the following expression:

$$
P_{t}=m\left(\mathbf{X}_{t}\right)+\epsilon_{t}, t=1, \ldots, T
$$

where $m\left(X_{t}\right)$ is an arbitrary fixed but unknown nonlinear function of a state variable $X_{t}$, and $\left\{\epsilon_{t}\right\}$ is white noise.

For the purposes of pattern recognition in which our goal is to construct a smooth function $\hat{m}(\cdot)$ to approximate the time series of prices $\left\{p_{t}\right\}$, we set the state variable equal to time, $X_{t}=t$. However, to keep our notation consistent with that of the kernel regression literature, we will continue to use $X_{t}$ in our exposition.

When prices are expressed as (1), it is apparent that geometric patterns can emerge from a visual inspection of historical prices series - prices are the sum of the nonlinear pattern $m\left(X_{t}\right)$ and white noise- and that such patterns may provide useful information about the unknown function $m(\cdot)$ to be estimated. But just how useful is this information?

To answer this question empirically and systematically, we must first develop a method for automating the identification of technical indicators, i.e., we require a pattern recognition algorithm. Once such an algorithm is developed, it can be applied to a large number of securities over many time periods to determine the efficacy of various technical indicators. Moreover, quantitative comparisons of the performance of several indicators can be conducted, and the statistical significance of such performance can be assessed through Monte Carlo simulation and bootstrap techniques. ${ }^{1}$

In Section A, we provide a brief review of a general class of pattern-recognition techniques known as smoothing, and in Section B we describe in some detail a particular method called nonparametric kernel regression on which our algorithm is based. Kernel regression estimators are calibrated by a bandwidth parameter and we discuss how the bandwidth is selected in C.

\section{A. Smoothing Estimators}

One of the most common methods for estimating nonlinear relations such as (1) is smoothing, in which observational errors are reduced by averaging the data in sophisticated ways. Ker- 
nel regression, orthogonal series expansion, projection pursuit, nearest-neighbor estimators, average derivative estimators, splines, and neural networks are all examples of smoothing estimators. In addition to possessing certain statistical optimality properties, smoothing estimators are motivated by their close correspondence to the way human cognition extracts regularities from noisy data. ${ }^{2}$ Therefore, they are ideal for our purposes.

To provide some intuition for how averaging can recover nonlinear relations such as the function $m(\cdot)$ in $(1)$, suppose we wish to estimate $m(\cdot)$ at a particular date $t_{0}$ when $X_{t_{0}}=x_{0}$. Now suppose that for this one observation, $X_{t_{0}}$, we can obtain repeated independent observations of the price $P_{t_{0}}$, say $P_{t_{0}}^{1}=p_{1}, \ldots, P_{t_{0}}^{n}=p_{n}$ (note that these are $n$ independent realizations of the price at the same date $t_{0}$, clearly an impossibility in practice, but let us continue with this thought experiment for a few more steps). Then a natural estimator of the function $m(\cdot)$ at the point $x_{0}$ is

$$
\begin{aligned}
\hat{m}\left(x_{0}\right) & =\frac{1}{n} \sum_{i=1}^{n} p_{i}=\frac{1}{n} \sum_{i=1}^{n}\left[m\left(x_{0}\right)+\epsilon_{t}^{i}\right] \\
& =m\left(x_{0}\right)+\frac{1}{n} \sum_{i=1}^{n} \epsilon_{t}^{i},
\end{aligned}
$$

and by the Law of Large Numbers, the second term in (3) becomes negligible for large $n$.

Of course, if $\left\{P_{t}\right\}$ is a time series, we do not have the luxury of repeated observations for a given $X_{t}$. However, if we assume that the function $m(\cdot)$ is sufficiently smooth, then for time-series observations $X_{t}$ near the value $x_{0}$, the corresponding values of $P_{t}$ should be close to $m\left(x_{0}\right)$. In other words, if $m(\cdot)$ is sufficiently smooth, then in a small neighborhood around $x_{0}, m\left(x_{0}\right)$ will be nearly constant and may be estimated by taking an average of the $P_{t}$ 's that correspond to those $X_{t}$ 's near $x_{0}$. The closer the $X_{t}$ 's are to the value $x_{0}$, the closer an average of corresponding $P_{t}$ 's will be to $m\left(x_{0}\right)$. This argues for a weighted average of the $P_{t}$ 's, where the weights decline as the $X_{t}$ 's get farther away from $x_{0}$. This weighted-average or "local averaging" procedure of estimating $m(x)$ is the essence of smoothing.

More formally, for any arbitrary $x$, a smoothing estimator of $m(x)$ may be expressed as

$$
\hat{m}(x) \equiv \frac{1}{T} \sum_{t=1}^{T} \omega_{t}(x) P_{t}
$$


where the weights $\left\{\omega_{t}(x)\right\}$ are large for those $P_{t}$ 's paired with $X_{t}$ 's near $x$, and small for those $P_{t}$ 's with $X_{t}$ 's far from $x$. To implement such a procedure, we must define what we mean by "near" and "far." If we choose too large a neighborhood around $x$ to compute the average, the weighted average will be too smooth and will not exhibit the genuine nonlinearities of $m(\cdot)$. If we choose too small a neighborhood around $x$, the weighted average will be too variable, reflecting noise as well as the variations in $m(\cdot)$. Therefore, the weights $\left\{\omega_{t}(x)\right\}$ must be chosen carefully to balance these two considerations.

\section{B. Kernel Regression}

For the kernel regression estimator, the weight function $\omega_{t}(x)$ is constructed from a probability density function $\mathrm{K}(x)$, also called a kernel:

$$
\mathrm{K}(x) \geq 0 \quad, \quad \int \mathrm{K}(u) d u=1
$$

By rescaling the kernel with respect to a parameter $h>0$, we can change its spread, i.e., let:

$$
\mathrm{K}_{h}(u) \equiv \frac{1}{h} \mathrm{~K}(u / h) \quad, \quad \int \mathrm{K}_{h}(u) d u=1
$$

and define the weight function to be used in the weighted average (4) as

$$
\begin{aligned}
\omega_{t, h}(x) & \equiv \mathrm{K}_{h}\left(x-X_{t}\right) / g_{h}(x) \\
g_{h}(x) & \equiv \frac{1}{T} \sum_{t=1}^{T} \mathrm{~K}_{h}\left(x-X_{t}\right)
\end{aligned}
$$

If $h$ is very small, the averaging will be done with respect to a rather small neighborhood around each of the $X_{t}$ 's. If $h$ is very large, the averaging will be over larger neighborhoods of the $X_{t}$ 's. Therefore, controlling the degree of averaging amounts to adjusting the smoothing parameter $h$, also known as the bandwidth. Choosing the appropriate bandwidth is an important aspect of any local-averaging technique and is discussed more fully in Section C. 
Substituting (8) into (4) yields the Nadaraya-Watson kernel estimator $\hat{m}_{h}(x)$ of $m(x)$ :

$$
\hat{m}_{h}(x)=\frac{1}{T} \sum_{t=1}^{T} \omega_{t, h}(x) Y_{t}=\frac{\sum_{t=1}^{T} K_{h}\left(x-X_{t}\right) Y_{t}}{\sum_{t=1}^{T} K_{h}\left(x-X_{t}\right)}
$$

Under certain regularity conditions on the shape of the kernel $\mathrm{K}$ and the magnitudes and behavior of the weights as the sample size grows, it may be shown that $\hat{m}_{h}(x)$ converges to $m(x)$ asymptotically in several ways (see Härdle (1990) for further details). This convergence property holds for a wide class of kernels, but for the remainder of this paper we shall use the most popular choice of kernel, the Gaussian kernel:

$$
\mathrm{K}_{h}(x)=\frac{1}{h \sqrt{2 \pi}} e^{-\frac{x^{2}}{2 h^{2}}}
$$

\section{Selecting the Bandwidth}

Selecting the appropriate bandwidth $h$ in (9) is clearly central to the success of $\hat{m}_{h}(\cdot)$ in approximating $m(\cdot)$ - too little averaging yields a function that is too choppy, and too much averaging yields a function that is too smooth. To illustrate these two extremes, Figure II displays the Nadaraya-Watson kernel estimator applied to 500 datapoints generated from the relation:

$$
Y_{t}=\operatorname{Sin}\left(X_{t}\right)+0.5 \epsilon_{t}, \epsilon_{t} \sim \mathcal{N}(0,1)
$$

where $X_{t}$ is evenly spaced in the interval $[0,2 \pi]$. Panel II(a) plots the raw data and the function to be approximated.

Kernel estimators for three different bandwidths are plotted as solid lines in Panels II(b)(c). The bandwidth in II(b) is clearly too small; the function is too variable, fitting the "noise" $0.5 \epsilon_{t}$ as well as the "signal" $\operatorname{Sin}(\cdot)$. Increasing the bandwidth slightly yields a much more accurate approximation to Sin (.) as Panel II(c) illustrates. However, Panel II(d) shows that if the bandwidth is increased beyond some point, there is too much averaging and information is lost.

There are several methods for automating the choice of bandwidth $h$ in (9), but the most 
popular is the cross-validation method in which $h$ is chosen to minimize the cross-validation function:

$$
\mathrm{CV}(h)=\frac{1}{T} \sum_{t=1}^{T}\left(P_{t}-\hat{m}_{h, t}\right)^{2}
$$

where

$$
\hat{m}_{h, t} \equiv \frac{1}{T} \sum_{\tau \neq t}^{T} \omega_{\tau, h} Y_{\tau}
$$

The estimator $\hat{m}_{h, t}$ is the kernel regression estimator applied to the price history $\left\{P_{\tau}\right\}$ with the $t$-th observation omitted, and the summands in (12) are the squared errors of the $\hat{m}_{h, t}$ 's, each evaluated at the omitted observation. For a given bandwidth parameter $h$, the crossvalidation function is a measure of the ability of the kernel regression estimator to fit each observation $P_{t}$ when that observation is not used to construct the kernel estimator. By selecting the bandwidth that minimizes this function, we obtain a kernel estimator that satisfies certain optimality properties, e.g., minimum asymptotic mean-squared error. ${ }^{4}$

Interestingly, the bandwidths obtained from minimizing the cross-validation function are generally too large for our application to technical analysis-when we presented several professional technical analysts with plots of cross-validation-fitted functions $\hat{m}_{h}(\cdot)$, they all concluded that the fitted functions were too smooth. In other words, the cross-validationdetermined bandwidth places too much weight on prices far away from any given time $t$, inducing too much averaging and discarding valuable information in local price movements. Through trial and error, and by polling professional technical analysts, we have found that an acceptable solution to this problem is to use a bandwidth of $0.3 \times h^{*}$, where $h^{*}$ minimizes $\mathrm{CV}(h) .{ }^{5}$ Admittedly, this is an ad hoc approach, and it remains an important challenge for future research to develop a more rigorous procedure.

Another promising direction for future research is to consider alternatives to kernel regression. Although useful for its simplicity and intuitive appeal, kernel estimators suffer from a number of well-known deficiencies, e.g., boundary bias, lack of local variability in the degree of smoothing, etc. A popular alternative that overcomes these particular defi- 
ciencies is local polynomial regression in which local averaging of polynomials is performed to obtain an estimator of $m(x) .{ }^{6}$ Such alternatives may yield important improvements the pattern-recognition algorithm described in Section II.

\section{Automating Technical Analysis}

Armed with a mathematical representation $\hat{m}(\cdot)$ of $\left\{P_{t}\right\}$ with which geometric properties can be characterized in an objective manner, we can now construct an algorithm for automating the detection of technical patterns. Specifically, our algorithm contains three steps:

1. Define each technical pattern in terms of its geometric properties, e.g., local extrema (maxima and minima).

2. Construct a kernel estimator $\hat{m}(\cdot)$ of a given time series of prices so that its extrema can be determined numerically.

3. Analyze $\hat{m}(\cdot)$ for occurrences of each technical pattern.

The last two steps are rather straightforward applications of kernel regression. The first step is likely to be the most controversial because it is here that the skills and judgment of a professional technical analyst come into play. Although we will argue in Section A that most technical indicators can be characterized by specific sequences of local extrema, technical analysts may argue that these are poor approximations to the kinds of patterns that trained human analysts can identify.

While pattern-recognition techniques have been successful in automating a number of tasks previously considered to be uniquely human endeavors-fingerprint identification, handwriting analysis, face recognition, and so on-nevertheless it is possible that no algorithm can completely capture the skills of an experienced technical analyst. We acknowledge that any automated procedure for pattern recognition may miss some of the more subtle nuances that human cognition is capable of discerning, but whether an algorithm is a poor approximation to human judgment can only be determined by investigating the approximation errors empirically. As long as an algorithm can provide a reasonable approximation to 
some of the cognitive abilities of a human analyst, we can use such an algorithm to investigate the empirical performance of those aspects of technical analysis for which the algorithm is a good approximation. Moreover, if technical analysis is an art form that can be taught, then surely its basic precepts can be quantified and automated to some degree. And as increasingly sophisticated pattern-recognition techniques are developed, a larger fraction of the art will become a science.

More importantly, from a practical perspective, there may be significant benefits to developing an algorithmic approach to technical analysis because of the leverage that technology can provide. As with many other successful technologies, the automation of technical pattern recognition may not replace the skills of a technical analyst, but can amplify them considerably.

In Section A, we propose definitions of ten technical patterns based on their extrema. In Section B, we describe a specific algorithm to identify technical patterns based on the local extrema of kernel regression estimators, and provide specific examples of the algorithm at work in Section C.

\section{A. Definitions of Technical Patterns}

We focus on five pairs of technical patterns that are among the most popular patterns of traditional technical analysis (see, for example, Edwards and Magee (1966, Chapters VII$\mathrm{X})$ ): head-and-shoulders (HS) and inverse head-and-shoulders (IHS), broadening tops (BT) and bottoms (BB), triangle tops (TT) and bottoms (TB), rectangle tops (RT) and bottoms (RB), and double tops (DT) and bottoms (DB). There are many other technical indicators that may be easier to detect algorithmically - moving averages, support and resistance levels, and oscillators, for example-but because we wish to illustrate the power of smoothing techniques in automating technical analysis, we focus on precisely those patterns that are most difficult to quantify analytically.

Consider the systematic component $m(\cdot)$ of a price history $\left\{P_{t}\right\}$ and suppose we have identified $n$ local extrema, i.e., the local maxima and minima, of $m(\cdot)$. Denote by $E_{1}, E_{2}, \ldots, E_{n}$ the $n$ extrema and $t_{1}^{*}, t_{2}^{*}, \ldots, t_{n}^{*}$ the dates on which these extrema occur. Then we have the following definitions: 
Definition 1 (Head-and-Shoulders) Head-and-shoulders (HS) and inverted head-andshoulders (IHS) patterns are characterized by a sequence of five consecutive local extrema $E_{1}, \ldots, E_{5}$ such that:

$$
\begin{array}{r}
H S \equiv\left\{\begin{array}{l}
E_{1} \text { a maximum } \\
E_{3}>E_{1}, E_{3}>E_{5} \\
E_{1} \text { and } E_{5} \text { within } 1.5 p e r c e n t \text { of their average } \\
E_{2} \text { and } E_{4} \text { within 1.5percent of their average }
\end{array}\right. \\
I H S \equiv\left\{\begin{array}{l}
E_{1} \text { a minimum } \\
E_{3}<E_{1}, E_{3}<E_{5} \\
E_{1} \text { and } E_{5} \text { within 1.5percent of their average } \\
E_{2} \text { and } E_{4} \text { within 1.5percent of their average }
\end{array}\right.
\end{array}
$$

Observe that only five consecutive extrema are required to identify a head-and-shoulders pattern. This follows from the formalization of the geometry of a head-and-shoulders pattern: three peaks, with the middle peak higher than the other two. Because consecutive extrema must alternate between maxima and minima for smooth functions, ${ }^{7}$ the three-peaks pattern corresponds to a sequence of five local extrema: maximum, minimum, highest maximum, minimum, and maximum. The inverse head-and-shoulders is simply the mirror image of the head-and-shoulders, with the initial local extrema a minimum.

Because broadening, rectangle, and triangle patterns can begin on either a local maximum or minimum, we allow for both of these possibilities in our definitions by distinguishing between broadening tops and bottoms:

Definition 2 (Broadening) Broadening tops (BTOP) and bottoms (BBOT) are characterized by a sequence of five consecutive local extrema $E_{1}, \ldots, E_{5}$ such that:

$$
B T O P \equiv\left\{\begin{array}{l}
E_{1} \text { a maximum } \\
E_{1}<E_{3}<E_{5} \\
E_{2}>E_{4}
\end{array} \quad, \quad B B O T \equiv\left\{\begin{array}{l}
E_{1} \text { a minimum } \\
E_{1}>E_{3}>E_{5} \\
E_{2}<E_{4}
\end{array}\right.\right.
$$

Definitions for triangle and rectangle patterns follow naturally:

Definition 3 (Triangle) Triangle tops (TTOP) and bottoms (TBOT) are characterized by a sequence of five consecutive local extrema $E_{1}, \ldots, E_{5}$ such that:

$$
T T O P \equiv\left\{\begin{array}{l}
E_{1} \text { a maximum } \\
E_{1}>E_{3}>E_{5} \\
E_{2}<E_{4}
\end{array} \quad, \quad T B O T \equiv\left\{\begin{array}{l}
E_{1} \text { a minimum } \\
E_{1}<E_{3}<E_{5} \\
E_{2}>E_{4}
\end{array}\right.\right.
$$


Definition 4 (Rectangle) Rectangle tops (RTOP) and bottoms (RBOT) are characterized by a sequence of five consecutive local extrema $E_{1}, \ldots, E_{5}$ such that:

$$
\begin{aligned}
& R T O P \equiv\left\{\begin{array}{l}
E_{1} \text { a maximum } \\
\text { tops within } 0.75 \text { percent of their average } \\
\text { bottoms within } 0.75 \text { percent of their average } \\
\text { lowest top }>\text { highest bottom }
\end{array}\right. \\
& R B O T \equiv\left\{\begin{array}{l}
E_{1} \text { a minimum } \\
\text { tops within } 0.75 \text { percent of their average } \\
\text { bottoms within } 0.75 \text { percent of their average } \\
\text { lowest top }>\text { highest bottom }
\end{array}\right.
\end{aligned}
$$

The definition for double tops and bottoms is slightly more involved. Consider first the double top. Starting at a local maximum $E_{1}$, we locate the highest local maximum $E_{a}$ occurring after $E_{1}$ in the set of all local extrema in the sample. We require that the two tops, $E_{1}$ and $E_{a}$, be within 1.5 percent of their average. Finally, following Edwards and Magee (1966), we require that the two tops occur at least a month, or 22 trading days, apart. Therefore, we have:

Definition 5 (Double Top and Bottom) Double tops (DTOP) and bottoms (DBOT) are characterized by an initial local extremum $E_{1}$ and a subsequent local extrema $E_{a}$ and $E_{b}$ such that:

$$
\begin{aligned}
& E_{a} \equiv \sup \left\{P_{t_{k}^{*}}: t_{k}^{*}>t_{1}^{*}, k=2, \ldots, n\right\} \\
& E_{b} \equiv \inf \left\{P_{t_{k}^{*}}: t_{k}^{*}>t_{1}^{*}, k=2, \ldots, n\right\}
\end{aligned}
$$

and

$$
\begin{aligned}
& D T O P \equiv\left\{\begin{array}{l}
E_{1} \text { a maximum } \\
E_{1} \text { and } E_{a} \text { within } 1.5 \text { percent of their average } \\
t_{a}^{*}-t_{1}^{*}>22
\end{array}\right. \\
& D B O T \equiv\left\{\begin{array}{l}
E_{1} \text { a minimum } \\
E_{1} \text { and } E_{b} \text { within } 1.5 \text { percent of their average } \\
t_{a}^{*}-t_{1}^{*}>22
\end{array}\right.
\end{aligned}
$$

\section{B. The Identification Algorithm}

Our algorithm begins with a sample of prices $\left\{P_{1}, \ldots, P_{T}\right\}$ for which we fit kernel regressions, one for each subsample or window from $t$ to $t+l+d-1$, where $t$ varies from 1 to $T-l-d+1$, 
and $l$ and $d$ are fixed parameters whose purpose is explained below. In the empirical analysis of Section III, we set $l=35$ and $d=3$, hence each window consists of 38 trading days.

The motivation for fitting kernel regressions to rolling windows of data is to narrow our focus to patterns that are completed within the span of the window- $l+d$ trading days in our case. If we fit a single kernel regression to the entire dataset, many patterns of various durations may emerge, and without imposing some additional structure on the nature of the patterns, it is virtually impossible to distinguish signal from noise in this case. Therefore, our algorithm fixes the length of the window at $l+d$, but kernel regressions are estimated on a rolling basis and we search for patterns in each window.

Of course, for any fixed window, we can only find patterns that are completed within $l+d$ trading days. Without further structure on the systematic component of prices $m(\cdot)$, this is a restriction that any empirical analysis must contend with. ${ }^{8}$ We choose a shorter window length of $l=35$ trading days to focus on short-horizon patterns that may be more relevant for active equity traders, and leave the analysis of longer-horizon patterns to future research.

The parameter $d$ controls for the fact that in practice we do not observe a realization of a given pattern as soon as it has completed. Instead, we assume that there may be a lag between the pattern completion and the time of pattern detection. To account for this lag, we require that the final extremum that completes a pattern occurs on day $t+l-1$; hence $d$ is the number of days following the completion of a pattern that must pass before the pattern is detected. This will become more important in Section III when we compute conditional returns, conditioned on the realization of each pattern. In particular, we compute postpattern returns starting from the end of trading day $t+l+d$, i.e., one day after the pattern has completed. For example, if we determine that a head-and-shoulder pattern has completed on day $t+l-1$ (having used prices from time $t$ through time $t+l+d-1$ ), we compute the conditional one-day gross return as $Z_{1} \equiv Y_{t+l+d+1} / Y_{t+l+d}$. Hence we do not use any forward information in computing returns conditional on pattern completion. In other words, the lag $d$ ensures that we are computing our conditional returns completely out-of-sample and without any "look-ahead" bias.

Within each window, we estimate a kernel regression using the prices in that window, 
hence:

$$
\hat{m}_{h}(\tau)=\frac{\sum_{s=t}^{t+l+d-1} \mathrm{~K}_{h}(\tau-s) P_{s}}{\sum_{s=t}^{t+l+d-1} \mathrm{~K}_{h}(\tau-s)}, t=1, \ldots, T-l-d+1
$$

where $\mathrm{K}_{h}(z)$ is given in (10) and $h$ is the bandwidth parameter (see Section C). It is clear that $\hat{m}_{h}(\tau)$ is a differentiable function of $\tau$.

Once the function $\hat{m}_{h}(\tau)$ has been computed, its local extrema can be readily identified by finding times $\tau$ such that $\operatorname{Sgn}\left(\hat{m}_{h}^{\prime}(\tau)\right)=-\operatorname{Sgn}\left(\hat{m}_{h}^{\prime}(\tau+1)\right)$, where $\hat{m}_{h}^{\prime}$ denotes the derivative of $\hat{m}_{h}$ with respect to $\tau$ and $\operatorname{Sgn}(\cdot)$ is the signum function. If the signs of $\hat{m}_{h}^{\prime}(\tau) \hat{m}_{h}^{\prime}(\tau+1)$ are +1 and -1 , respectively, then we have found a local maximum, and if they are -1 and +1 , respectively, then we have found a local minimum. Once such a time $\tau$ has been identified, we proceed to identify a maximum or minimum in the original price series $\left\{P_{t}\right\}$ in the range $[t-1, t+1]$, and the extrema in the original price series are used to determine whether or not a pattern has occurred according to the definitions of Section $A$.

If $\hat{m}_{h}^{\prime}(\tau)=0$ for a given $\tau$, which occurs if closing prices stay the same for several consecutive days, we need to check whether the price we have found is a local minimum or maximum. We look for the date $s$ such that $s=\inf \left\{s>\tau: \hat{m}_{h}^{\prime}(s) \neq 0\right\}$. We then apply the same method as discussed above, except here we compare $\operatorname{Sgn}\left(\hat{m}_{h}^{\prime}(\tau-1)\right)$ and $\operatorname{Sgn}\left(\hat{m}_{h}^{\prime}(s)\right)$.

One useful consequence of this algorithm is that the series of extrema which it identifies contains alternating minima and maxima. That is, if the $k^{\text {th }}$ extremum is a maximum, then it is always the case that the $(k+1)^{\text {th }}$ extremum is a minimum, and vice versa.

An important advantage of using this kernel regression approach to identify patterns is the fact that it ignores extrema that are "too local." For example, a simpler alternative is to identify local extrema from the raw price data directly, i.e., identify a price $P_{t}$ as a local maximum if $P_{t-1}<P_{t}$ and $P_{t}>P_{t+1}$, and vice versa for a local minimum. The problem with this approach is that it identifies too many extrema, and also yields patterns that are not visually consistent with the kind of patterns that technical analysts find compelling.

Once we have identified all of the local extrema in the window $[t, t+l+d-1]$, we can proceed to check for the presence of the various technical patterns using the definitions of 
Section A. This procedure is then repeated for the next window $[t+1, t+l+d]$, and continues until the end of the sample is reached at the window $[T-l-d+1, T]$.

\section{Empirical Examples}

To see how our algorithm performs in practice, we apply it to the daily returns of a single security, CTX, during the five-year period from 1992 to 1996. Figures III-VII plot occurrences of the five pairs of patterns defined in Section A that were identified by our algorithm. Note that there were no rectangle bottoms detected for CTX during this period, so for completeness we substituted a rectangle bottom for CDO stock which occurred during the same period.

In each of these graphs, the solid lines are the raw prices, the dashed lines are the kernel estimators $\hat{m}_{h}(\cdot)$, the circles indicate the local extrema, and the vertical line marks date $t+l-1$, the day that the final extremum occurs to complete the pattern.

Casual inspection by several professional technical analysts seems to confirm the ability of our automated procedure to match human judgment in identifying the five pairs of patterns in Section A. Of course, this is merely anecdotal evidence and not meant to be conclusivewe provide these figures simply to illustrate the output of a technical pattern recognition algorithm based on kernel regression.

\section{Is Technical Analysis Informative?}

Although there have been many tests of technical analysis over the years, most of these tests have focused on the profitability of technical trading rules. ${ }^{9}$ While some of these studies do find that technical indicators can generate statistically significant trading profits, they beg the question of whether or not such profits are merely the equilibrium rents that accrue to investors willing to bear the risks associated with such strategies. Without specifying a fully articulated dynamic general equilibrium asset-pricing model, it is impossible to determine the economic source of trading profits.

Instead, we propose a more fundamental test in this section, one that attempts to gauge the information content in the technical patterns of Section A by comparing the unconditional 
empirical distribution of returns with the corresponding conditional empirical distribution, conditioned on the occurrence of a technical pattern. If technical patterns are informative, conditioning on them should alter the empirical distribution of returns; if the information contained in such patterns has already been incorporated into returns, the conditional and unconditional distribution of returns should be close. Although this is a weaker test of the effectiveness of technical analysis - informativeness does not guarantee a profitable trading strategy -it is, nevertheless, a natural first step in a quantitative assessment of technical analysis.

To measure the distance between the two distributions, we propose two goodness-of-fit measures in Section A. We apply these diagnostics to the daily returns of individual stocks from 1962 to 1996 using a procedure described in Sections B to D, and the results are reported in Sections E and F.

\section{A. Goodness-of-Fit Tests}

A simple diagnostic to test the informativeness of the ten technical patterns is to compare the quantiles of the conditional returns with their unconditional counterparts. If conditioning on these technical patterns provides no incremental information, the quantiles of the conditional returns should be similar to those of unconditional returns. In particular, we compute the deciles of unconditional returns and tabulate the relative frequency $\hat{\delta}_{j}$ of conditional returns falling into decile $j$ of the unconditional returns, $j=1, \ldots, 10$ :

$$
\hat{\delta}_{j} \equiv \frac{\text { number of conditional returns in decile } j}{\text { total number of conditional returns }} .
$$

Under the null hypothesis that the returns are independently and identically distributed and the conditional and unconditional distributions are identical, the asymptotic distributions of $\hat{\delta}_{j}$ and the corresponding goodness-of-fit test statistic $Q$ are given by:

$$
\begin{aligned}
& \sqrt{n}\left(\hat{\delta}_{j}-0.10\right) \stackrel{a}{\sim} \mathcal{N}(0,0.10(1-0.10)) \\
& Q \equiv \sum_{j=1}^{10} \frac{\left(n_{j}-0.10 n\right)^{2}}{0.10 n} \stackrel{a}{\sim} \chi_{9}^{2}
\end{aligned}
$$


where $n_{j}$ is the number of observations that fall in decile $j$ and $n$ is the total number of observations (see, for example, DeGroot (1986)).

Another comparison of the conditional and unconditional distributions of returns is provided by the Kolmogorov-Smirnov test. Denote by $\left\{Z_{1 t}\right\}_{t=1}^{n_{1}}$ and $\left\{Z_{2 t}\right\}_{t=1}^{n_{2}}$ two samples that are each independently and identically distributed with cumulative distribution functions $F_{1}(z)$ and $F_{2}(z)$, respectively. The Kolmogorov-Smirnov statistic is designed to test the null hypothesis that $F_{1}=F_{2}$, and is based on the empirical cumulative distribution functions $\hat{F}_{i}$ of both samples:

$$
\hat{F}_{i}(z) \equiv \frac{1}{n_{i}} \sum_{k=1}^{n_{i}} \mathbf{1}\left(Z_{i k} \leq z\right), i=1,2
$$

where $\mathbf{1}(\cdot)$ is the indicator function. The statistic is given by the expression:

$$
\gamma_{n_{1}, n_{2}}=\left(\frac{n_{1} n_{2}}{n_{1}+n_{2}}\right)^{1 / 2} \sup _{-\infty<z<\infty}\left|\hat{F}_{1}(z)-\hat{F}_{2}(z)\right| .
$$

Under the null hypothesis $F_{1}=F_{2}$, the statistic $\gamma_{n_{1}, n_{2}}$ should be small. Moreover, Smirnov (1939a, 1939b) derives the limiting distribution of the statistic to be:

$$
\lim _{\min \left(n_{1}, n_{2}\right) \rightarrow \infty} \operatorname{Prob}\left(\gamma_{n_{1}, n_{2}} \leq x\right)=\sum_{k=-\infty}^{\infty}(-1)^{k} \exp \left(-2 k^{2} x^{2}\right), x>0
$$

An approximate $\alpha$-level test of the null hypothesis can be performed by computing the statistic and rejecting the null if it exceeds the upper $100 \alpha$-th percentile for the null distribution given by (20) (see Hollander and Wolfe (1973, Table A.23), Csáki (1984), and Press et al. (1986, Chapter 13.5)).

Note that the sampling distributions of both the goodness-of-fit and Kolmogorov-Smirnov statistics are derived under the assumption that returns are independently and identically distributed, which is not plausible for financial data. We attempt to address this problem by normalizing the returns of each security, i.e., by subtracting its mean and dividing by its standard deviation (see Section C), but this does not eliminate the dependence or heterogeneity. We hope to extend our analysis to the more general non-IID case in future 
research.

\section{B. The Data and Sampling Procedure}

We apply the goodness-of-fit and Kolmogorov-Smirnov tests to the daily returns of individual NYSE/AMEX and Nasdaq stocks from 1962 to 1996 using data from the Center for Research in Securities Prices (CRSP). To ameliorate the effects of nonstationarities induced by changing market structure and institutions, we split the data into NYSE/AMEX stocks and Nasdaq stocks and into seven five-year periods: 1962 to 1966,1967 to 1971, and so on. To obtain a broad cross-section of securities, in each five-year subperiod, we randomly select ten stocks from each of five market-capitalization quintiles (using mean market-capitalization over the subperiod), with the further restriction that at least 75 percent of the price observations must be non-missing during the subperiod. ${ }^{10}$ This procedure yields a sample of 50 stocks for each subperiod across seven subperiods (note that we sample with replacement, hence there may be names in common across subperiods).

As a check on the robustness of our inferences, we perform this sampling procedure twice to construct two samples, and apply our empirical analysis to both. Although we report results only from the first sample to conserve space, the results of the second sample are qualitatively consistent with the first and are available upon request.

\section{Computing Conditional Returns}

For each stock in each subperiod, we apply the procedure outlined in Section II to identify all occurrences of the ten patterns defined in Section A. For each pattern detected, we compute the one-day continuously compounded return $d$ days after the pattern has completed. Specifically, consider a window of prices $\left\{P_{t}\right\}$ from $t$ to $t+l+d-1$, and suppose that the identified pattern $p$ is completed at $t+l-1$. Then we take the conditional return $R^{p}$ as $\log \left(1+R_{t+l+d+1}\right)$. Therefore, for each stock, we have ten sets of such conditional returns, each conditioned on one of the ten patterns of Section A.

For each stock, we construct a sample of unconditional continuously compounded returns using non-overlapping intervals of length $\tau$, and we compare the empirical distribution function of these returns with those of the conditional returns. To facilitate such comparisons, 
we standardize all returns--both conditional and unconditional-by subtracting means and dividing by standard deviations, hence:

$$
X_{i t}=\frac{R_{i t}-\operatorname{Mean}\left[R_{i t}\right]}{\operatorname{SD}\left[R_{i t}\right]}
$$

where the means and standard deviations are computed for each individual stock within each subperiod. Therefore, by construction, each normalized return series has zero mean and unit variance.

Finally, to increase the power of our goodness-of-fit tests, we combine the normalized returns of all 50 stocks within each subperiod; hence for each subperiod we have two samplesunconditional and conditional returns - and from these we compute two empirical distribution functions that we compare using our diagnostic test statistics.

\section{Conditioning on Volume}

Given the prominent role that volume plays in technical analysis, we also construct returns conditioned on increasing or decreasing volume. Specifically, for each stock in each subperiod, we compute its average share-turnover during the first and second halves of each subperiod, $\tau_{1}$ and $\tau_{2}$, respectively. ${ }^{11}$ If $\tau_{1}>1.2 \times \tau_{2}$, we categorize this as a "decreasing volume" event;

if $\tau_{2}>1.2 \times \tau_{1}$, we categorize this as an "increasing volume" event. If neither of these conditions holds, then neither event is considered to have occurred.

Using these events, we can construct conditional returns conditioned on two pieces of information: the occurrence of a technical pattern and the occurrence of increasing or decreasing volume. Therefore, we shall compare the empirical distribution of unconditional returns with three conditional-return distributions: the distribution of returns conditioned on technical patterns, the distribution conditioned on technical patterns and increasing volume, and the distribution conditioned on technical patterns and decreasing volume.

Of course, other conditioning variables can easily be incorporated into this procedure, though the "curse of dimensionality" imposes certain practical limits on the ability to estimate multivariate conditional distributions nonparametrically. 


\section{E. Summary Statistics}

In Tables I and II, we report frequency counts for the number of patterns detected over the entire 1962 to 1996 sample, and within each subperiod and each market-capitalization quintile, for the ten patterns defined in Section A. Table I contains results for the NYSE/AMEX stocks, and Table II contains corresponding results for Nasdaq stocks.

Table I shows that the most common patterns across all stocks and over the entire sample period are double tops and bottoms (see the row labelled "Entire"), with over 2,000 occurrences of each. The second most common patterns are the head-and-shoulders and inverted head-and-shoulders, with over 1,600 occurrences of each. These total counts correspond roughly to four to six occurrences of each of these patterns for each stock during each five-year subperiod (divide the total number of occurrences by $7 \times 50$ ), not an unreasonable frequency from the point of view of professional technical analysts. Table I shows that most of the ten patterns are more frequent for larger stocks than for smaller ones, and that they are relatively evenly distributed over the five-year subperiods. When volume trend is considered jointly with the occurrences of the ten patterns, Table I shows that the frequency of patterns is not evenly distributed between increasing (the row labelled " $\tau(\lambda)$ ") and decreasing (the row labelled " $\tau(\diamond)$ ") volume-trend cases. For example, for the entire sample of stocks over the 1962 to 1996 sample period, there are 143 occurrences of a broadening top with decreasing volume trend, but 409 occurrences of a broadening top with increasing volume trend.

For purposes of comparison, Table I also reports frequency counts for the number of patterns detected in a sample of simulated geometric Brownian motion, calibrated to match the mean and standard deviation of each stock in each five-year subperiod. ${ }^{12}$ The entries in the row labelled "Sim. GBM" show that the random walk model yields very different implications for the frequency counts of several technical patterns. For example, the simulated sample has only 577 head-and-shoulders and 578 inverted-head-and-shoulders patterns, whereas the actual data have considerably more, 1,611 and 1,654, respectively. On the other hand, for broadening tops and bottoms, the simulated sample contains many more occurrences than the actual data, 1,227 and 1,028 as compared to 725 and 748 , respectively. The number of 
triangles is roughly comparable across the two samples, but for rectangles and double tops and bottoms, the differences are dramatic. Of course, the simulated sample is only one realization of geometric Brownian motion, so it is difficult to draw general conclusions about the relative frequencies. Nevertheless, these simulations point to important differences between the data and independently and identically distributed lognormal returns.

To develop further intuition for these patterns, Figures VIII and IX display the crosssectional and time-series distribution of each of the ten patterns for the NYSE/AMEX and Nasdaq samples, respectively. Each symbol represents a pattern detected by our algorithm, the vertical axis is divided into five quintiles, the horizontal axis is calendar time, and alternating symbols (diamonds and asterisks) represent distinct subperiods. These graphs show that the distribution of patterns is not clustered in time or among a subset of securities.

Table II provides the same frequency counts for Nasdaq stocks, and despite the fact that we have the same number of stocks in this sample ( 50 per subperiod over seven subperiods), there are considerably fewer patterns detected than in the NYSE/AMEX case. For example, the Nasdaq sample yields only 919 head-and-shoulders patterns, whereas the NYSE/AMEX sample contains 1,611 . Not surprisingly, the frequency counts for the sample of simulated geometric Brownian motion are similar to those in Table I.

Tables III and IV report summary statistics-means, standard deviations, skewness, and excess kurtosis-of unconditional and conditional normalized returns of NYSE/AMEX and Nasdaq stocks, respectively. These statistics show considerable variation in the different return populations. For example, the first four moments of normalized raw returns are 0.000 , $1.000,0.345$, and 8.122 , respectively. The same four moments of post-BTOP returns are $-0.005,1.035,-1.151$, and 16.701 , respectively, and those of post-DTOP returns are 0.017 , $0.910,0.206$, and 3.386 , respectively. The differences in these statistics among the ten conditional return populations, and the differences between the conditional and unconditional return populations, suggest that conditioning on the ten technical indicators does have some effect on the distribution of returns. 


\section{F. Empirical Results}

Tables V and VI reports the results of the goodness-of-fit test (16)-(17) for our sample of NYSE and AMEX (Table V) and Nasdaq (Table VI) stocks, respectively, from 1962 to 1996 for each of the ten technical patterns. Table V shows that in the NYSE/AMEX sample, the relative frequencies of the conditional returns are significantly different from those of the unconditional returns for seven of the ten patterns considered. The three exceptions are the conditional returns from the BBOT, TTOP, and DBOT patterns, for which the $p$-values of the test statistics $Q$ are 5.1 percent, 21.2 percent, and 16.6 percent respectively. These results yield mixed support for the overall efficacy of technical indicators. However, the results of Table VI tell a different story: there is overwhelming significance for all ten indicators in the Nasdaq sample, with $p$-values that are zero to three significant digits, and test statistics $Q$ that range from 34.12 to 92.09 . In contrast, the test statistics in Table V range from 12.03 to 50.97 .

One possible explanation for the difference between the NYSE/AMEX and Nasdaq samples is a difference in the power of the test because of different sample sizes. If the NYSE/AMEX sample contained fewer conditional returns, i.e., fewer patterns, the corresponding test statistics might be subject to greater sampling variation and lower power. However, this explanation can be ruled out from the frequency counts of Tables I and IIthe number of patterns in the NYSE/AMEX sample is considerably larger than those of the Nasdaq sample for all ten patterns. Tables V and VI seem to suggest important differences in the informativeness of technical indicators for NYSE/AMEX and Nasdaq stocks.

Table VII and VIII report the results of the Kolmogorov-Smirnov test (19) of the equality of the conditional and unconditional return distributions for NYSE/AMEX (Table VII) and Nasdaq (Table VIII) stocks, respectively, from 1962 to 1996, in five-year subperiods, and in market-capitalization quintiles. Recall that conditional returns are defined as the oneday return starting three days following the conclusion of an occurrence of a pattern. The $p$-values are with respect to the asymptotic distribution of the Kolmogorov-Smirnov test statistic given in (20).

Table VII shows that for NYSE/AMEX stocks, five of the ten patterns--HS, BBOT, 
RTOP, RBOT, and DTOP-yield statistically significant test statistics, with $p$-values ranging from 0.000 for RBOT to 0.021 for DTOP patterns. However, for the other five patterns, the $p$-values range from 0.104 for IHS to 0.393 for DBOT, which implies an inability to distinguish between the conditional and unconditional distributions of normalized returns.

When we condition on declining volume trend as well, the statistical significance declines for most patterns, but increases the statistical significance of TBOT patterns. In contrast, conditioning on increasing volume trend yields an increase in the statistical significance of BTOP patterns. This difference may suggest an important role for volume trend in TBOT and BTOP patterns. The difference between the increasing and decreasing volume-trend conditional distributions is statistically insignificant for almost all the patterns (the sole exception is the TBOT pattern). This drop in statistical significance may be due to a lack of power of the K-S test given the relatively small sample sizes of these conditional returns (see Table I for frequency counts).

Table VIII reports corresponding results for the Nasdaq sample and as in Table VI, in contrast to the NYSE/AMEX results, here all the patterns are statistically significant at the 5 percent level. This is especially significant because the the Nasdaq sample exhibits far fewer patterns than the NYSE/AMEX sample (see Tables I and II), hence the K-S test is likely to have lower power in this case.

As with the NYSE/AMEX sample, volume trend seems to provide little incremental information for the Nasdaq sample except in one case: increasing volume and BTOP. And except for the TTOP pattern, the K-S test still cannot distinguish between the decreasing and increasing volume-trend conditional distributions, as the last pair of rows of Table VIII's first panel indicates.

\section{Monte Carlo Analysis}

Tables IX and X contain bootstrap percentiles for the Kolmogorov-Smirnov test of the equality of conditional and unconditional one-day return distributions for NYSE/AMEX and Nasdaq stocks, respectively, from 1962 to 1996 , and for market-capitalization quintiles, under the null hypothesis of equality. For each of the two sets of market data, two sample sizes, 
$m_{1}$ and $m_{2}$, have been chosen to span the range of frequency counts of patterns reported in Tables I and II. For each sample size $m_{i}$, we resample one-day normalized returns (with replacement) to obtain a bootstrap sample of $m_{i}$ observations, compute the KolmogorovSmirnov test statistic (against the entire sample of one-day normalized returns), and repeat this procedure 1,000 times. The percentiles of the asymptotic distribution are also reported for comparison under the column " $\gamma$ ".

Tables IX and $\mathrm{X}$ show that for a broad range of sample sizes and across size quintiles, subperiod, and exchanges, the bootstrap distribution of the Kolmogorov-Smirnov statistic is well approximated by its asymptotic distribution (20).

\section{Conclusion}

In this paper, we have proposed a new approach to evaluating the efficacy of technical analysis. Based on smoothing techniques such as nonparametric kernel regression, our approach incorporates the essehce of technical analysis: to identify regularities in the time series of prices by extracting nonlinear patterns from noisy data. While human judgment is still superior to most computational algorithms in the area of visual pattern recognition, recent advances in statistical learning theory have had successful applications in fingerprint identification, handwriting analysis, and face recognition. Technical analysis may well be the next frontier for such methods.

When applied to many stocks over many time periods, we find that certain technical patterns do provide incremental information, especially for Nasdaq stocks. While this does not necessarily imply that technical analysis can be used to generate "excess" trading profits, it does raise the possibility that technical analysis can add value to the investment process.

Moreover, our methods suggest that technical analysis can be improved by using automated algorithms such as ours, and that traditional patterns such as head-and-shoulders and rectangles, while sometimes effective, need not be optimal. In particular, it may be possible to determine "optimal patterns" for detecting certain types of phenomena in financial time series, e.g., an optimal shape for detecting stochastic volatility or changes in regime. Moreover, patterns that are optimal for detecting statistical anomalies need not be optimal for 
trading profits, and vice versa. Such considerations may lead to an entirely new branch of technical analysis, one based on selecting pattern recognition algorithms to optimize specific objective functions. We hope to explore these issues more fully in future research. 


\section{Footnotes}

${ }^{1}$ A similar approach has been proposed by Chang and Osler (1994) and Osler and Chang (1995) for the case of foreign-currency trading rules based on a head-and-shoulders pattern. They develop an algorithm for automatically detecting geometric patterns in price or exchange data by looking at properly defined local extrema.

${ }^{2}$ See, for example, Beymer and Poggio (1996), Poggio and Beymer (1996), and Riesenhuber and Poggio (1997).

${ }^{3}$ Despite the fact that $K(x)$ is a probability density function, it plays no probabilistic role in the subsequent analysis - it is merely a convenient method for computing a weighted average, and does not imply, for example, that $X$ is distributed according to $\mathrm{K}(x)$ (which would be a parametric assumption).

${ }^{4}$ However, there are other bandwidth-selection methods that yield the same asymptotic optimality properties but which have different implications for the finite-sample properties of kernel estimators. See Härdle (1990) for further discussion.

${ }^{5}$ Specifically, we produced fitted curves for various bandwidths and compared their extrema to the original price series visually to see if we were fitting more "noise" than "signal," and asked several professional technical analysts to do the same. Through this informal process, we settled on the bandwidth of $0.3 \times h^{*}$ and used it for the remainder of our analysis. This procedure was followed before we performed the statistical analysis of Section III, and we made no revision to the choice of bandwidth afterwards.

${ }^{6}$ See Simonoff (1996) for a discussion of the problems with kernel estimators and alternatives such as local polynomial regression.

${ }^{7}$ After all, for two consecutive maxima to be local maxima, there must be a local minimum in between, and vice versa for two consecutive minima.

${ }^{8}$ If we are willing to place additional restrictions on $m(\cdot)$, e.g., linearity, we can obtain considerably more accurate inferences even for partially completed patterns in any fixed window.

${ }^{9}$ For example, Chang and Osler (1994) and Osler and Chang (1995) propose an algorithm. for automatically detecting head-and-shoulders patterns in foreign exchange data by looking at properly defined local extrema. To assess the efficacy of a head-and-shoulders trading rule, they take a stand on a class of trading strategies and compute the profitability of these across a sample of exchange rates against the U.S. dollar. The null return distribution is computed by a bootstrap that samples returns randomly from the original data so as to induce temporal independence in the bootstrapped time series. By comparing the actual returns from trading strategies to the bootstrapped distribution, the authors find that for two of the six currencies in their sample (the yen and the Deutsche mark), trading strategies based on a head and shoulders pattern can lead to statistically significant profits. See, also, Neftci and Policano (1984), Pruitt and White (1988), and Brock, Lakonishok, and LeBaron (1992).

${ }^{10}$ If the first price observation of a stock is missing, we set it equal to the first non-missing price in the series. If the $t$-th price observation is missing, we set it equal to the first non-missing price prior to $t$.

${ }^{11}$ For the Nasdaq stocks, $\tau_{1}$ is the average turnover over the first third of the sample, and $\tau_{2}$ is the average turnover over the final third of the sample. 
${ }^{12}$ In particular, let the price process satisfy

$$
d P(t)=\mu P(t) d t+\sigma P(t) d W(t)
$$

where $W(t)$ is a standard Brownian motion. To generate simulated prices for a single security in a given period, we estimate the security's drift and diffusion coefficients by maximum likelihood and then simulate prices using the estimated parameter values. An independent price series is simulated for each of the 350 securities in both the NYSE/AMEX and the Nasdaq samples. Finally, we use our pattern recognition algorithm to detect the occurrence of each of the ten patterns in the simulated price series. 


\section{References}

Allen, Franklin and Risto Karjalainen, 1999, Using genetic algorithms to find technical trading rules, Journal of Financial Economics 51, 245-271.

Beymer, David and Tomaso Poggio, 1996, Image representation for visual learning, Science 272, 1905-1909.

Blume, Lawrence, Easley, David and Maureen O'Hara, 1994, Market statistics and technical analysis: The role of volume, Journal of Finance 49, 153-181.

Brock, William, Lakonishok, Joseph and Blake LeBaron, 1992, Simple technical trading rules and the stochastic properties of stock returns, Journal of Finance 47, 1731-1764.

Brown, David and Robert Jennings, 1989, On technical analysis, Review of Financial Studies 2, 527-551.

Campbell, John, Lo, Andrew W. and A. Craig MacKinlay, 1997, The Econometrics of Financial Markets. Princeton, NJ: Princeton University Press.

Chan, Louis, Jegadeesh, Narasimhan and Joseph Lakonishok, 1996, Momentum strategies, Journal of Finance 51, 1681-1713.

Chang, Kevin and Carol Osler, 1994, Evaluating chart-based technical analysis: The headand-shoulders pattern in foreign exchange markets, working paper, Federal Reserve Bank of New York.

Csáki, E., 1984, Empirical distribution function, in P. Krishnaiah and P. Sen, eds., Handbook of Statistics, Volume 4 (Elsevier Science Publishers, Amsterdam, The Netherlands).

DeGroot, Morris, 1986, Probability and Statistics (Addison Wesley Publishing Company, Reading, MA).

Edwards, Robert and John Magee, 1966, Technical Analysis of Stock Trends, 5th Edition (John Magee Inc., Boston, MA).

Grundy, Bruce and S. Martin, 1998, Understanding the nature of the risks and the source of the rewards to momentum investing, unpublished working paper, Wharton School, University of Pennsylvania.

Härdle, Wolfgang, 1990, Applied Nonparametric Regression (Cambridge University Press, Cambridge, UK).

Hollander, Myles and Douglas Wolfe, 1973, Nonparametric Statistical Methods (John Wiley \& Sons, New York, NY).

Jegadeesh, Narasimhan and Sheridan Titman, 1993, Returns to buying winners and selling losers: Implications for stock market efficiency, Journal of Finance 48, 65-91.

Lo, Andrew W. and A. Craig MacKinlay, 1988, Stock market prices do not follow random walks: Evidence from a simple specification test, Review of Financial Studies 1, 41-66.

Lo, Andrew W. and A. Craig MacKinlay, 1997, Maximizing predictability in the stock and bond markets, Macroeconomic Dynamics 1(1997), 102-134. 
Lo, Andrew W. and A. Craig MacKinlay, 1999, A Non-Random Walk Down Wall Street (Princeton University Press, Princeton, NJ).

Malkiel, Burton, 1996, A Random Walk Down Wall Street: Including a Life-Cycle Guide to Personal Investing (W.W. Norton, New York, NY).

Neely, Christopher, Weller, Peter and Robert Dittmar, 1997, Is technical analysis in the foreign exchange market profitable? A genetic programming approach, Journal of Financial and Quantitative Analysis 32, 405-426.

Neely, Christopher and Peter Weller, 1998, Technical trading rules in the european monetary system, working paper, Federal Bank of St. Louis.

Neftci, Salih, 1991, Naive trading rules in financial markets and wiener-kolmogorov prediction theory: A study of technical analysis, Journal of Business 64, 549-571.

Neftci, Salih and Andrew Policano, 1984, Can chartists outperform the market? Market efficiency tests for 'technical analyst', Journal of Future Markets 4, 465-478.

Osler, Carol and Kevin Chang, 1995, Head and shoulders: Not just a flaky pattern, Staff Report No. 4, Federal Reserve Bank of New York.

Poggio, Tomaso and David Beymer, 1996, Regularization networks for visual learning, in Shree Nayar and Tomaso Poggio, eds., Early Visual Learning (Oxford University Press, Oxford, UK).

Press, William, Flannery, Brian, Teukolsky, Saul and William Vetterling, 1986, Numerical Recipes: The Art of Scientific Computing (Cambridge University Press, Cambridge, $\mathrm{UK}$ ).

Pruitt, Stephen and Robert White, 1988, The CRISMA trading system: Who says technical analysis can't beat the market?, Journal of Portfolio Management 14, 55-58.

Riesenhuber, Maximilian and Tomaso Poggio, 1997, Common computational strategies in machine and biological vision, in Proceedings of International Symposium on System Life. Tokyo, Japan, 67-75.

Rouwenhorst, Geert, 1998, International momentum strategies, Journal of Finance 53, $267-284$.

Simonoff, Jeffrey, 1996, Smoothing Methods in Statistics (Springer-Verlag, New York, NY).

Smirnov, N., 1939a, Sur les écarts de la courbe de distribution empirique, Rec. Math. (Mat. Sborn.) 6, 3-26.

Smirnov, N., 1939b, On the estimation of the discrepancy between empirical curves of distribution for two independent samples, Bulletin. Math. Univ. Moscow 2, 3-14.

Tabell, Anthony and Edward Tabell, 1964, The case for technical analysis, Financial Analyst Journal 20, 67-76.

Treynor, Jack and Robert Ferguson, 1985, In defense of technical analysis, Journal of Finance 40, 757-773. 

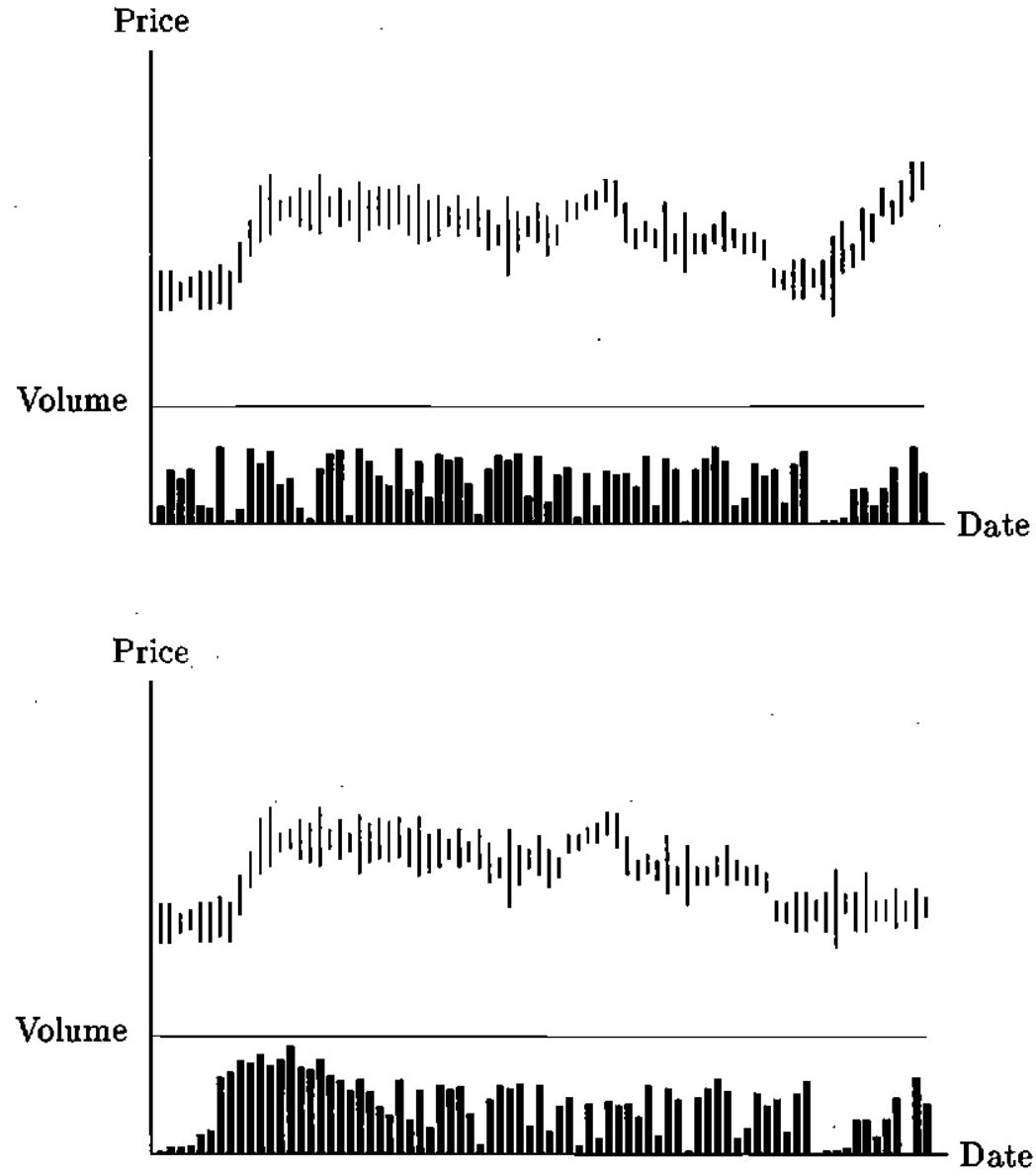

Figure I. Two hypothetical price/volume charts. 


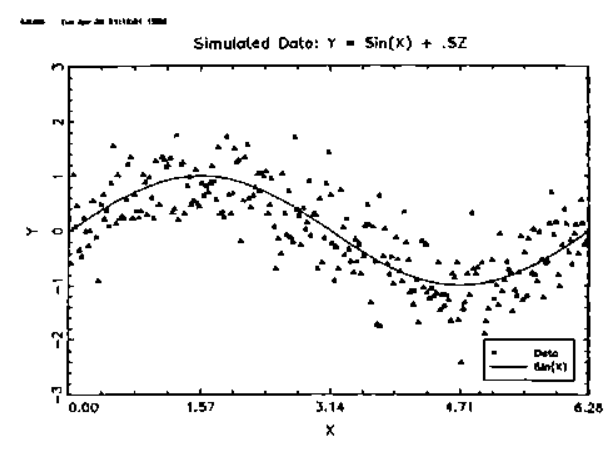

(a)

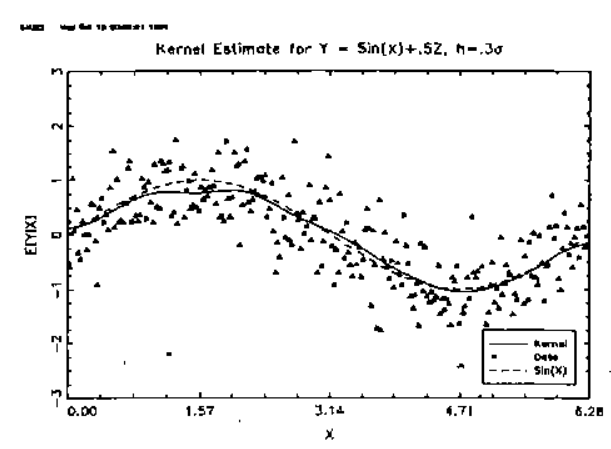

(c)

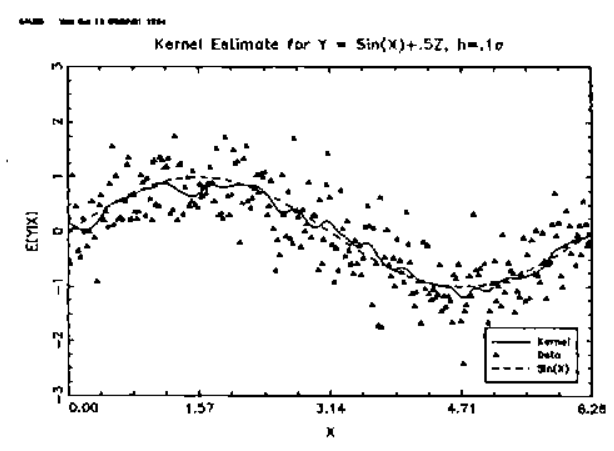

(b)

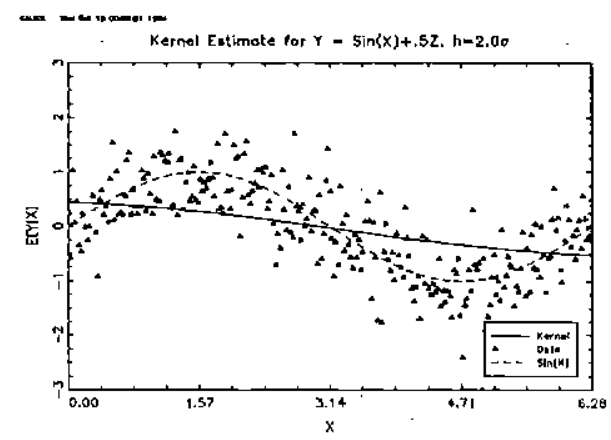

(d)

Figure II. Illustration of bandwidth selection for kernel regression.

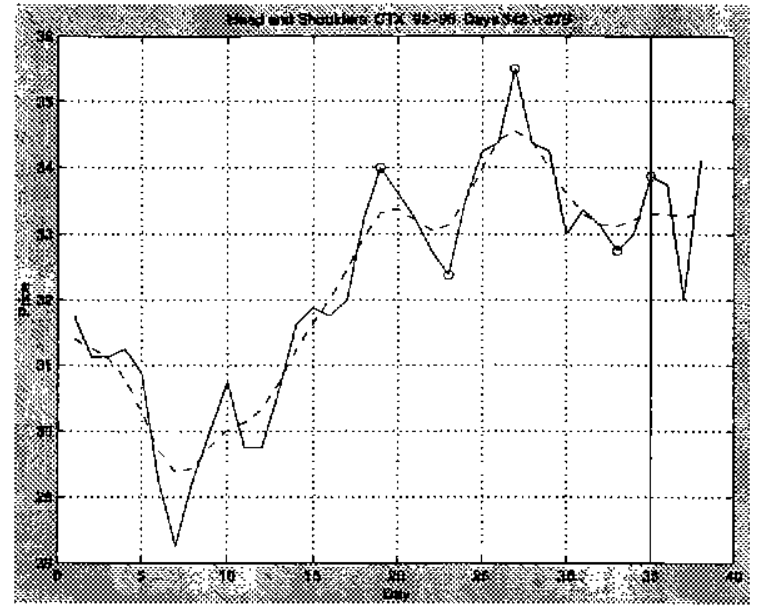

(a) Head-and-Shoulders

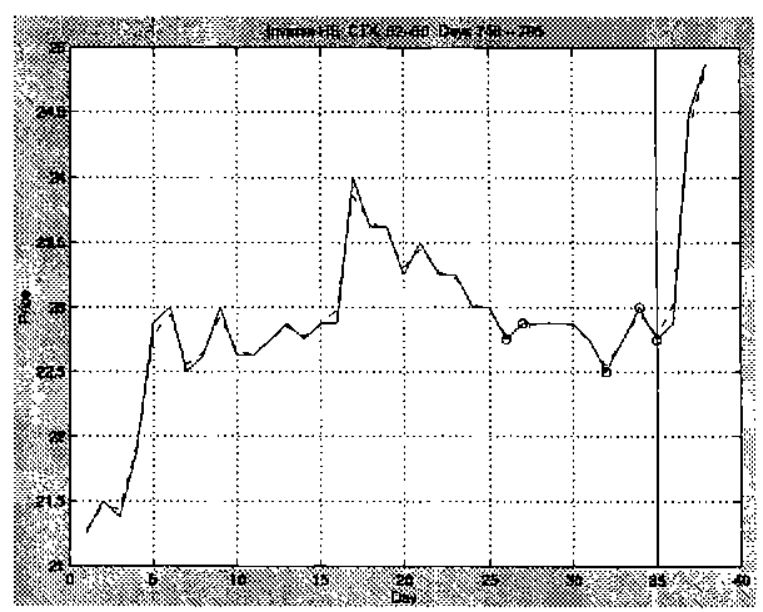

(b) Inverse Head-end-Shoulders

Figure III. Head-and-shoulders and inverse head-and-shoulders. 


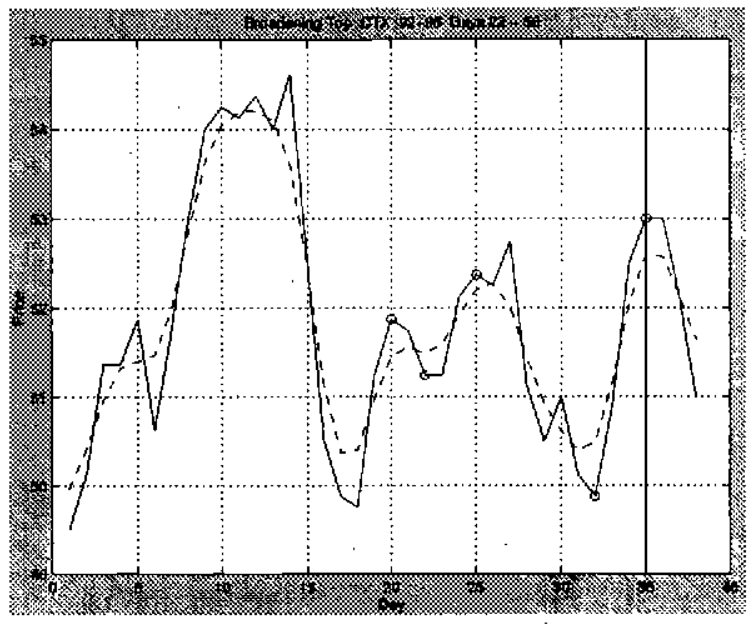

(a) Brosdening Top

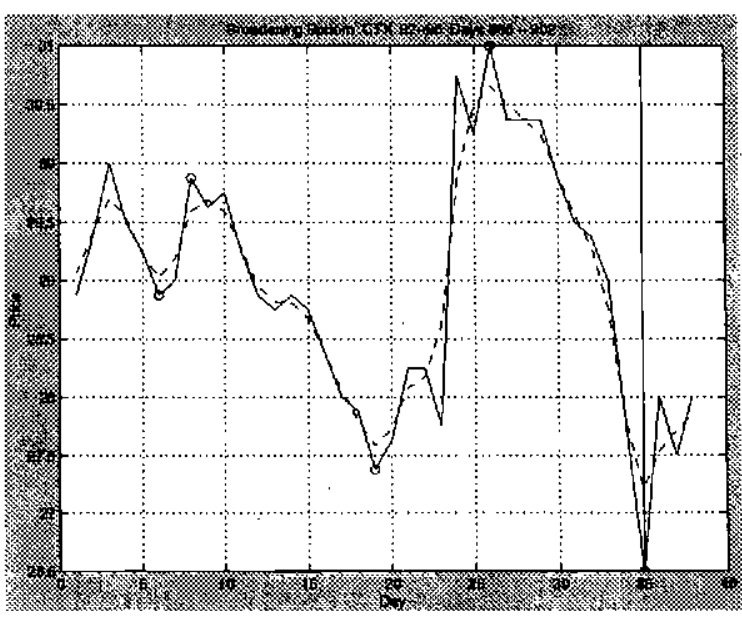

(b) Broadening Bottom

Figure IV. Broadening tops and bottoms.

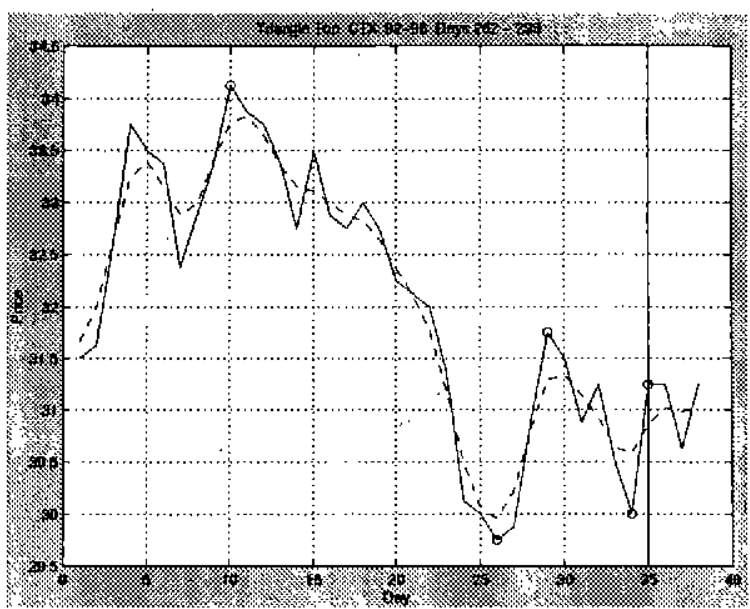

(a) Triangle Top

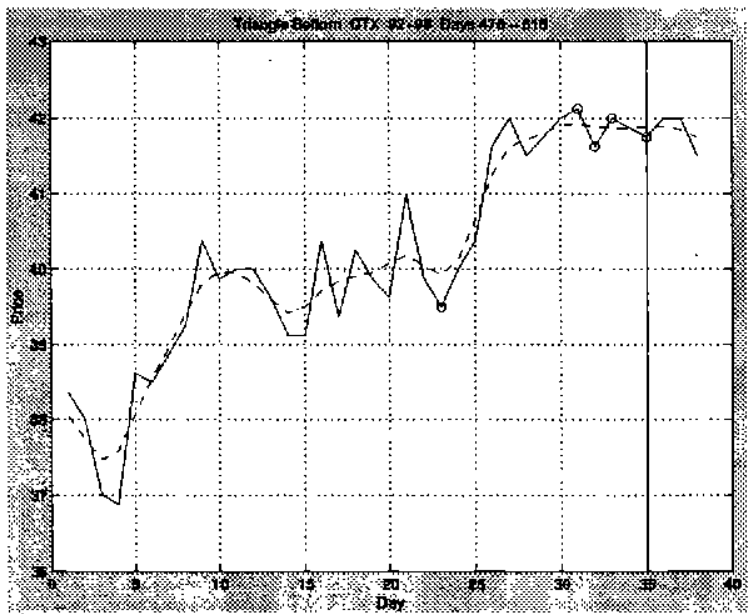

(b) Triangle Bottom

Figure V. Triangle tops and bottoms. 


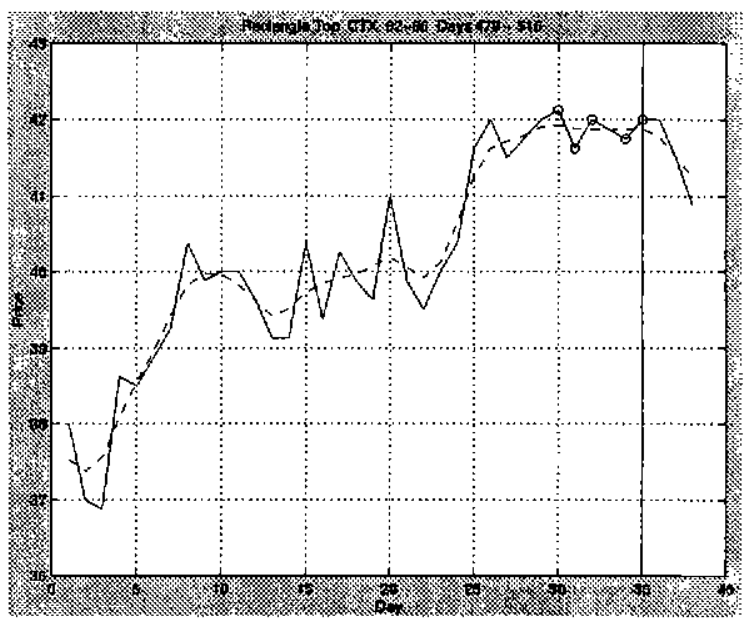

(a) Rectangle Top

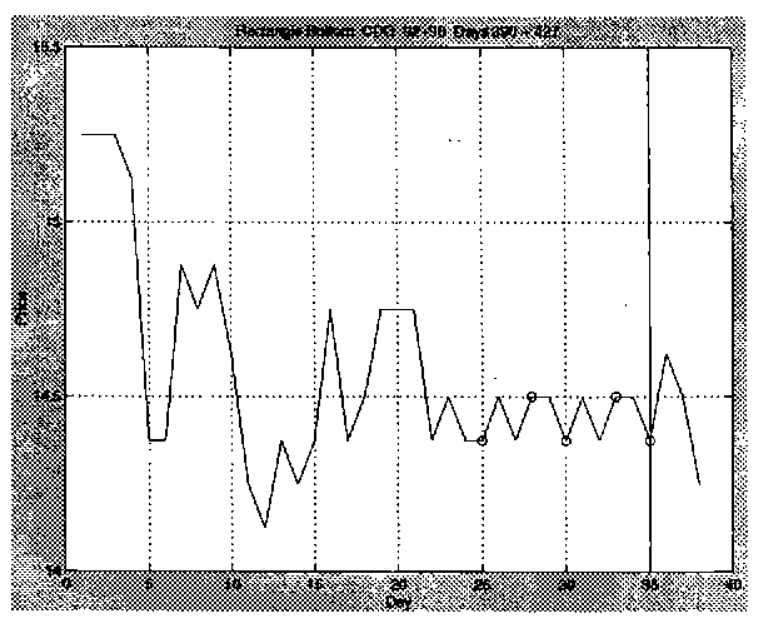

(b) Rectangle Bottom

Figure VI. Rectangle tops and bottoms.

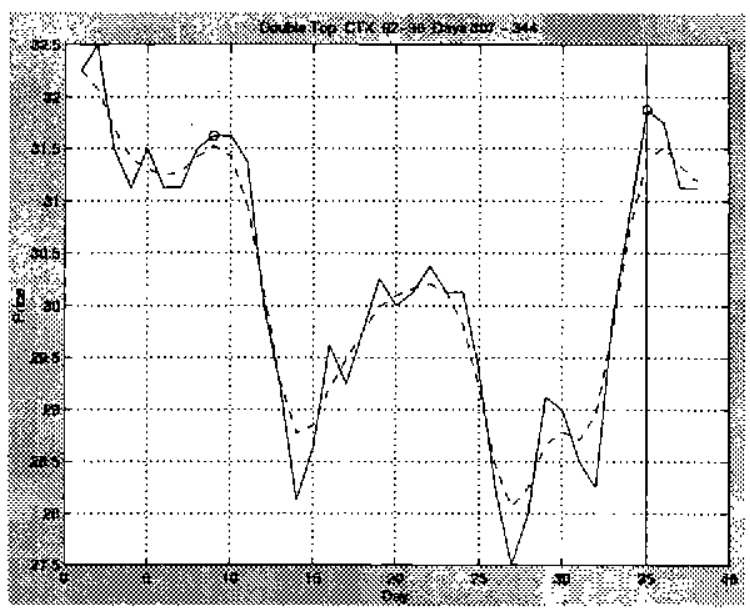

(a) Double Top

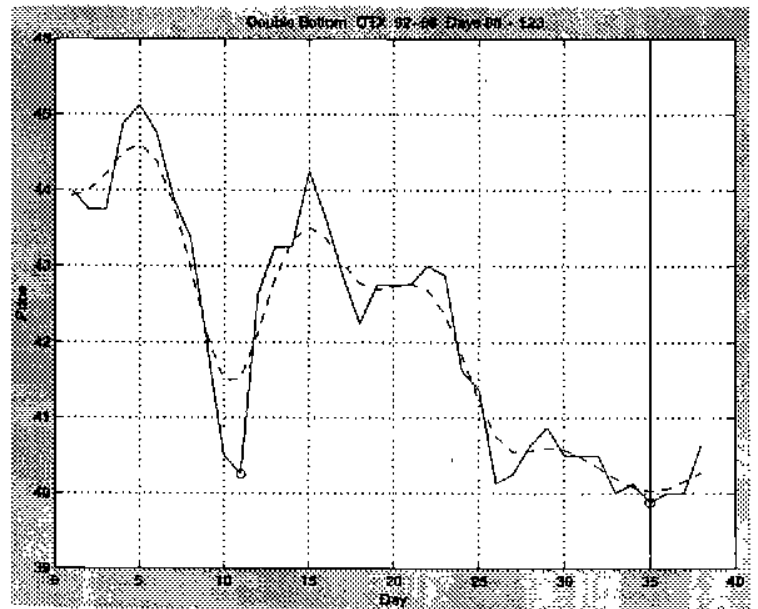

(b) Double Bottom

Figure VII. Double tops and bottoms. 


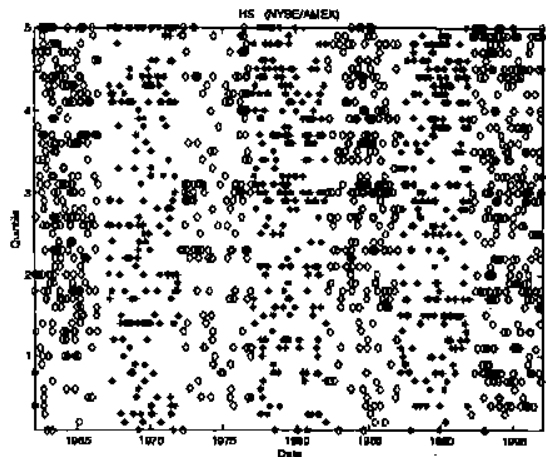

(a)

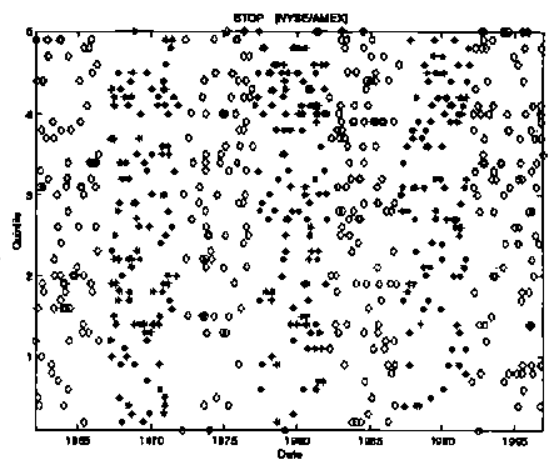

(c)

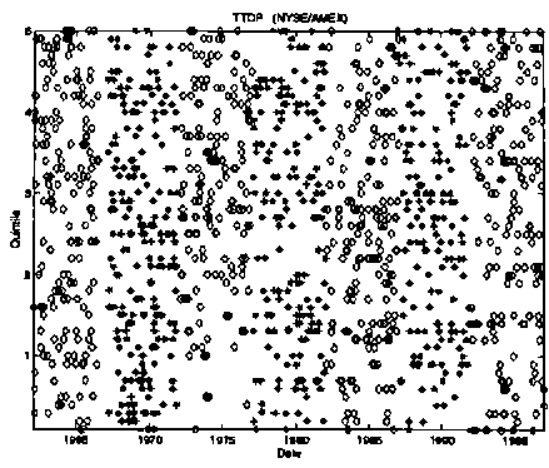

(e)

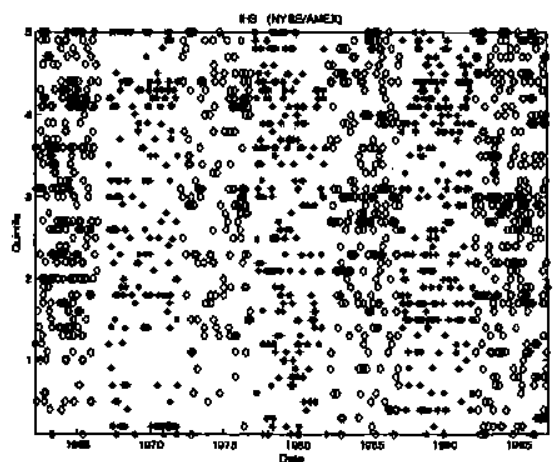

(b)

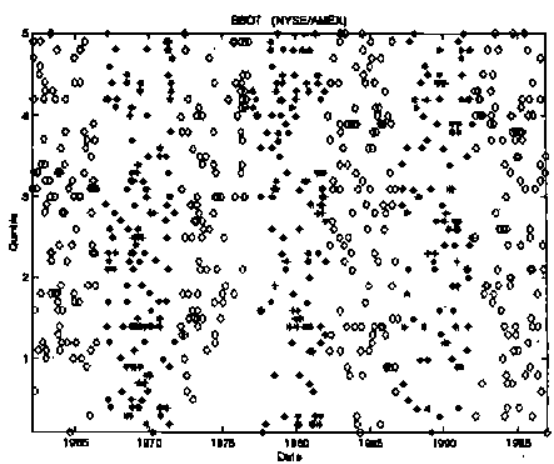

(d)

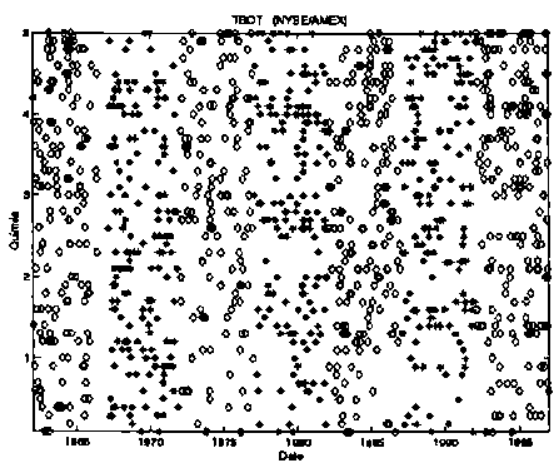

(f)

Figure VIII. Distribution of patterns in NYSE/AMEX sample. 


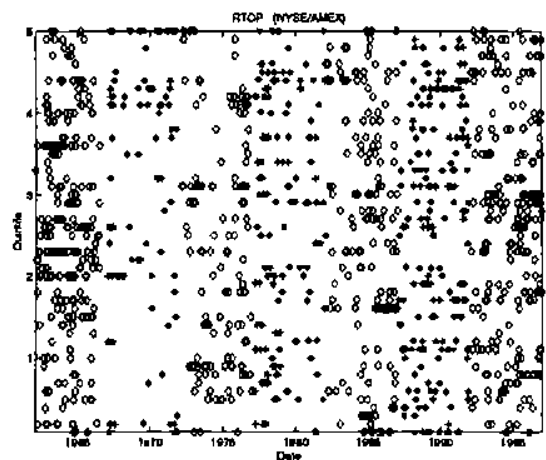

(g)

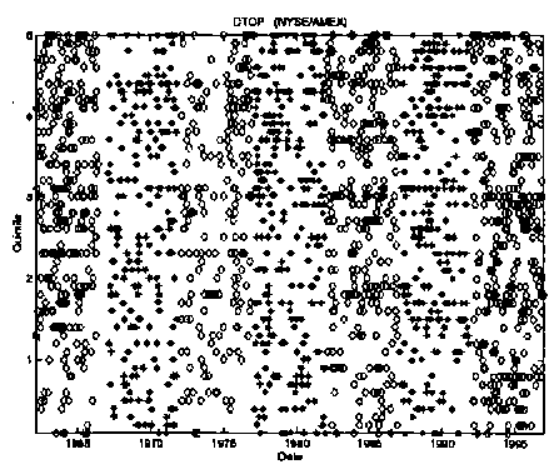

(i)

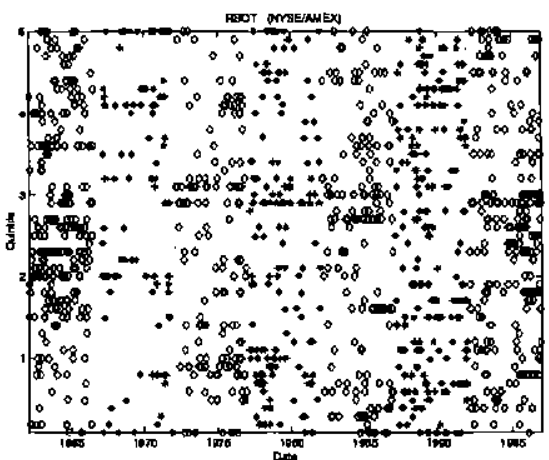

(h)

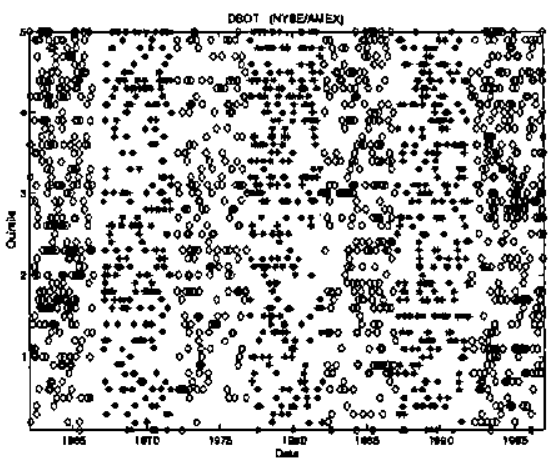

(j)

Figure VIII. (continued). 


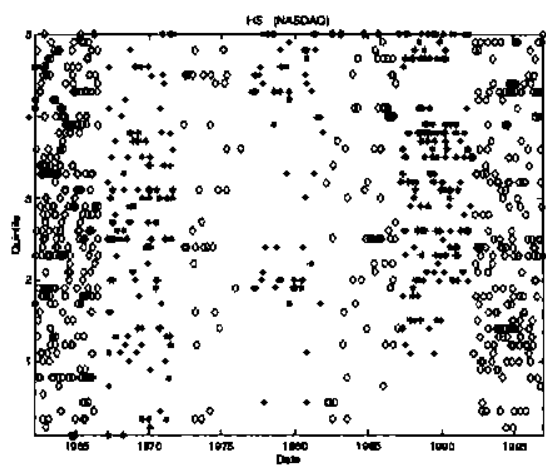

(a)

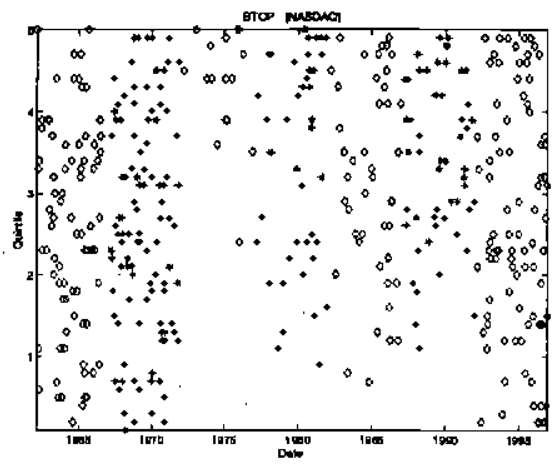

(c)

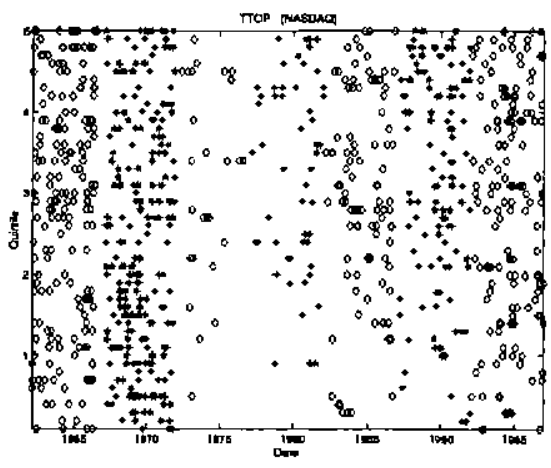

(e)

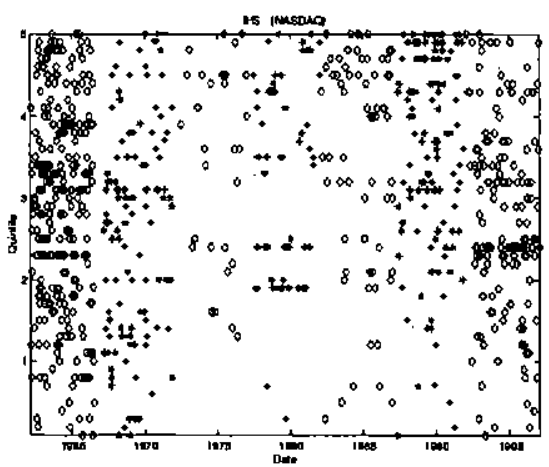

(b)

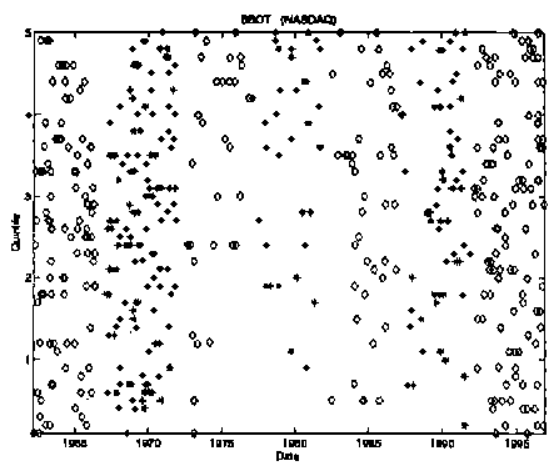

(d)

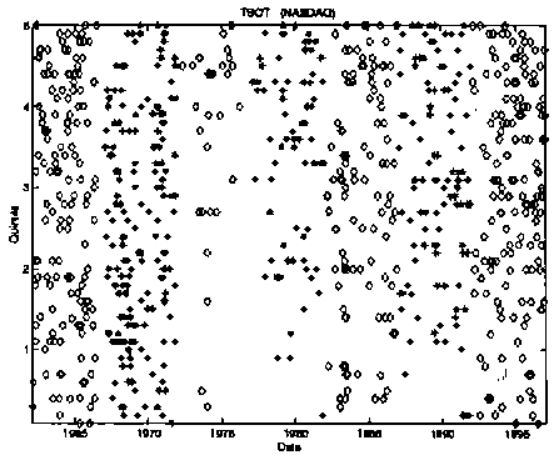

(f)

Figure IX. Distribution of patterns in NASDAQ sample. 


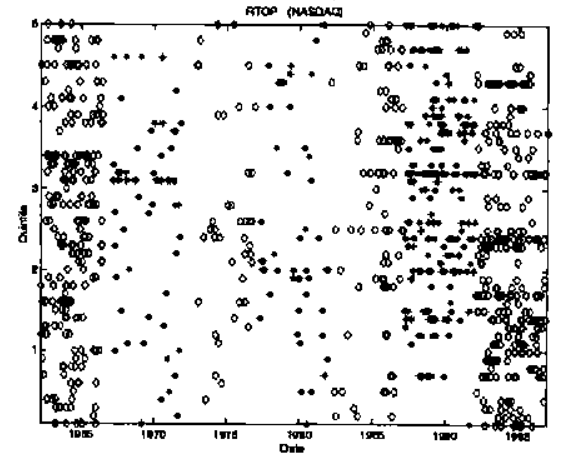

(g)

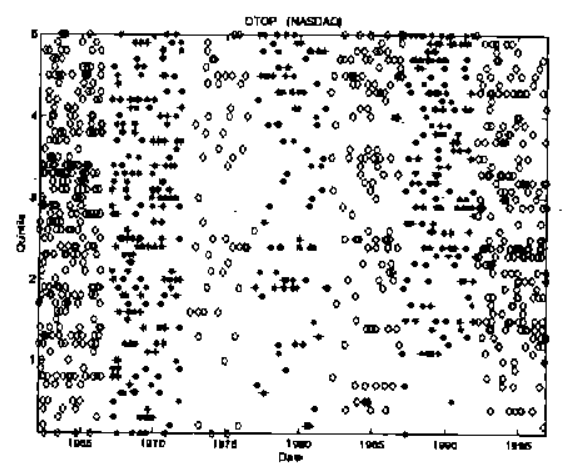

(i)

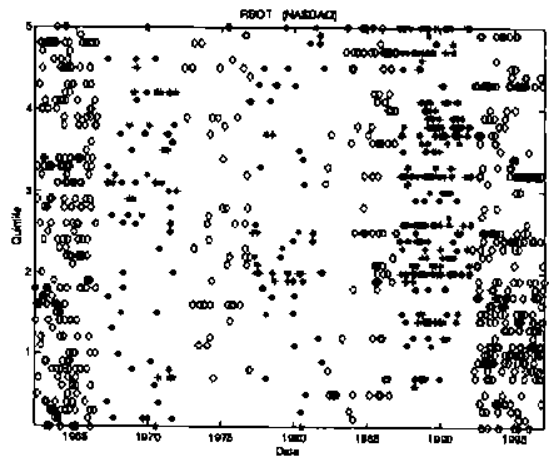

(h)

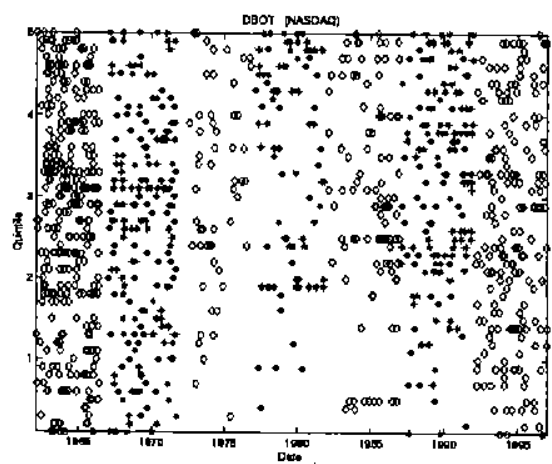

(j)

Figure IX. (continued). 


\section{Table I}

Frequency counts for 10 technical indicators detected among NYSE/AMEX stocks from 1962 to 1996, in 5-year subperiods, in size quintiles, and in a sample of simulated geometric Brownian motion. In each 5-year subperiod, 10 stocks per quintile are selected at random among stocks with at least $80 \%$ non-missing prices, and each stock's price history is scanned for any occurrence of the following 10 technical indicators within the subperiod: head-and-shoulders (HS), inverted headand-shoulders (IHS), broadening top (BTOP), broadening bottom (BBOT), triangle top (TTOP), triangle bottom (TBOT), rectangle top (RTOP), rectangle bottom (RBOT), double top (DTOP), and double bottom (DBOT). The 'Sample' column indicates whether the frequency counts are conditioned on decreasing volume trend (' $\tau(\chi)$ '), increasing volume trend (' $\tau(\nearrow)$ '), unconditional ('Entire'), or for a sample of simulated geometric Brownian motion with parameters calibrated to match the data ('Sim. GBM').

\begin{tabular}{|c|c|c|c|c|c|c|c|c|c|c|c|}
\hline Sample & Raw & HS & IHS & BTOP & BBOT & TTOP & TBOT & RTOP & RBOT & DTOP & DBOT \\
\hline \multicolumn{12}{|c|}{ All Stocks, 1962 to 1996} \\
\hline $\begin{array}{l}\text { Entire } \\
\text { Sim. GBM } \\
\tau(\nu) \\
\tau(\lambda)\end{array}$ & $\begin{array}{c}423,556 \\
423,556 \\
- \\
-\end{array}$ & $\begin{array}{r}1611 \\
577 \\
655 \\
553\end{array}$ & $\begin{array}{r}1654 \\
578 \\
593 \\
614\end{array}$ & $\begin{array}{r}725 \\
1227 \\
143 \\
409\end{array}$ & $\begin{array}{r}748 \\
1028 \\
220 \\
337\end{array}$ & $\begin{array}{r}1294 \\
1049 \\
666 \\
300\end{array}$ & $\begin{array}{r}1193 \\
1176 \\
710 \\
222\end{array}$ & $\begin{array}{r}1482 \\
122 \\
582 \\
523\end{array}$ & $\begin{array}{r}1616 \\
113 \\
637 \\
552\end{array}$ & $\begin{array}{r}2076 \\
535 \\
691 \\
776\end{array}$ & $\begin{array}{r}2075 \\
574 \\
974 \\
533\end{array}$ \\
\hline \multicolumn{12}{|c|}{ Smallest Quintile, 1962 to 1996} \\
\hline $\begin{array}{l}\text { Entire } \\
\text { Sim. GBM } \\
\tau(y) \\
\tau(\mu)\end{array}$ & $\begin{array}{l}84,363 \\
84,363 \\
-\end{array}$ & $\begin{array}{r}182 \\
82 \\
90 \\
58\end{array}$ & $\begin{array}{r}181 \\
99 \\
81 \\
76\end{array}$ & $\begin{array}{r}78 \\
279 \\
13 \\
51\end{array}$ & $\begin{array}{r}97 \\
256 \\
42 \\
37\end{array}$ & $\begin{array}{r}203 \\
269 \\
122 \\
41\end{array}$ & $\begin{array}{r}159 \\
295 \\
119 \\
22\end{array}$ & $\begin{array}{r}265 \\
18 \\
113 \\
99\end{array}$ & $\begin{array}{r}320 \\
16 \\
131 \\
120\end{array}$ & $\begin{array}{r}261 \\
129 \\
78 \\
124\end{array}$ & $\begin{array}{r}271 \\
127 \\
161 \\
64\end{array}$ \\
\hline \multicolumn{12}{|c|}{ 2nd Quintile, 1962 to 1996} \\
\hline $\begin{array}{l}\text { Entire } \\
\text { Sim. GBM } \\
\tau(\nu) \\
\tau(\lambda)\end{array}$ & $\begin{array}{c}83,986 \\
83,986 \\
- \\
-\end{array}$ & $\begin{array}{l}309 \\
108 \\
133 \\
112\end{array}$ & $\begin{array}{l}321 \\
105 \\
126 \\
126\end{array}$ & $\begin{array}{r}146 \\
291 \\
25 \\
90\end{array}$ & $\begin{array}{r}150 \\
251 \\
48 \\
63\end{array}$ & $\begin{array}{r}255 \\
261 \\
135 \\
55\end{array}$ & $\begin{array}{r}228 \\
278 \\
147 \\
39\end{array}$ & $\begin{array}{r}299 \\
20 \\
130 \\
104\end{array}$ & $\begin{array}{r}322 \\
17 \\
149 \\
110\end{array}$ & $\begin{array}{l}372 \\
106 \\
113 \\
153\end{array}$ & $\begin{array}{l}420 \\
126 \\
211 \\
107\end{array}$ \\
\hline \multicolumn{12}{|c|}{ 3rd Quintile, 1962 to 1996} \\
\hline $\begin{array}{l}\text { Entire } \\
\text { Sim. GBM } \\
\tau(\nu) \\
\tau(\lambda)\end{array}$ & $\begin{array}{c}84,420 \\
84,420 \\
-\end{array}$ & $\begin{array}{l}361 \\
122 \\
152 \\
125\end{array}$ & $\begin{array}{l}388 \\
120 \\
131 \\
146\end{array}$ & $\begin{array}{r}145 \\
268 \\
20 \\
83\end{array}$ & $\begin{array}{r}161 \\
222 \\
49 \\
66\end{array}$ & $\begin{array}{r}291 \\
212 \\
151 \\
67\end{array}$ & $\begin{array}{r}247 \\
249 \\
149 \\
44\end{array}$ & $\begin{array}{r}334 \\
24 \\
130 \\
121\end{array}$ & $\begin{array}{r}399 \\
31 \\
160 \\
142\end{array}$ & $\begin{array}{l}458 \\
115 \\
154 \\
179\end{array}$ & $\begin{array}{l}443 \\
125 \\
215 \\
106\end{array}$ \\
\hline \multicolumn{12}{|c|}{ 4th Quintile, 1962 to 1996} \\
\hline $\begin{array}{l}\text { Entire } \\
\text { Sim. GBM } \\
\tau(x) \\
\tau(\lambda)\end{array}$ & $\begin{array}{c}84,780 \\
84,780 \\
-\end{array}$ & $\begin{array}{l}332 \\
143 \\
131 \\
110\end{array}$ & $\begin{array}{l}317 \\
127 \\
115 \\
126\end{array}$ & $\begin{array}{r}176 \\
249 \\
36 \\
103\end{array}$ & $\begin{array}{r}173 \\
210 \\
42 \\
89\end{array}$ & $\begin{array}{r}262 \\
183 \\
138 \\
56\end{array}$ & $\begin{array}{r}255 \\
210 \\
145 \\
55\end{array}$ & $\begin{array}{r}259 \\
35 \\
85 \\
102\end{array}$ & $\begin{array}{r}264 \\
24 \\
97 \\
96\end{array}$ & $\begin{array}{l}424 \\
116 \\
144 \\
147\end{array}$ & $\begin{array}{l}420 \\
122 \\
184 \\
118\end{array}$ \\
\hline \multicolumn{12}{|c|}{ Largest Quintile, 1962 to 1996} \\
\hline $\begin{array}{l}\text { Entire } \\
\text { Sim. GBM } \\
r(\nu) \\
\tau(\lambda) .\end{array}$ & $\begin{array}{l}86,007 \\
86,007 \\
-\end{array}$ & $\begin{array}{l}427 \\
122 \\
149 \\
148\end{array}$ & $\begin{array}{l}447 \\
127 \\
140 \\
140\end{array}$ & $\begin{array}{r}180 \\
140 \\
49 \\
82\end{array}$ & $\begin{array}{r}167 \\
89 \\
39 \\
82\end{array}$ & $\begin{array}{r}283 \\
124 \\
120 \\
81\end{array}$ & $\begin{array}{r}304 \\
144 \\
150 \\
62\end{array}$ & $\begin{array}{r}325 \\
25 \\
124 \\
97\end{array}$ & $\begin{array}{r}311 \\
25 \\
100 \\
84\end{array}$ & $\begin{array}{r}561 \\
69 \\
202 \\
173\end{array}$ & $\begin{array}{r}521 \\
74 \\
203 \\
138\end{array}$ \\
\hline
\end{tabular}


Table I (continued)

\begin{tabular}{|c|c|c|c|c|c|c|c|c|c|c|c|}
\hline Sample & Raw & HS & IHS & BTOP & BBOT & TTOP & TBOT & RTOP & RBOT & DTOP & DBOT \\
\hline \multicolumn{12}{|c|}{ All Stocks, 1962 to 1966} \\
\hline $\begin{array}{l}\text { Entire } \\
\text { Sim. GBM } \\
\tau(x) \\
\tau(\Lambda)\end{array}$ & $\begin{array}{c}55,254 \\
55,254 \\
- \\
-\end{array}$ & $\begin{array}{r}276 \\
56 \\
104 \\
96\end{array}$ & $\begin{array}{r}278 \\
58 \\
88 \\
112\end{array}$ & $\begin{array}{r}85 \\
144 \\
26 \\
44\end{array}$ & $\begin{array}{r}103 \\
126 \\
29 \\
39\end{array}$ & $\begin{array}{r}179 \\
129 \\
93 \\
37\end{array}$ & $\begin{array}{r}165 \\
139 \\
109 \\
25\end{array}$ & $\begin{array}{r}316 \\
9 \\
130 \\
130\end{array}$ & $\begin{array}{r}354 \\
16 \\
141 \\
122\end{array}$ & $\begin{array}{r}356 \\
60 \\
113 \\
137\end{array}$ & $\begin{array}{r}352 \\
68 \\
188 \\
88\end{array}$ \\
\hline \multicolumn{12}{|c|}{ All Stocks, 1967 to 1971} \\
\hline $\begin{array}{l}\text { Entire } \\
\text { Sim. GBM } \\
\tau(\searrow) \\
\tau(\Lambda)\end{array}$ & $\begin{array}{c}60,299 \\
60,299 \\
- \\
-\end{array}$ & $\begin{array}{r}179 \\
92 \\
68 \\
71\end{array}$ & $\begin{array}{r}175 \\
70 \\
64 \\
69\end{array}$ & $\begin{array}{r}112 \\
167 \\
16 \\
68\end{array}$ & $\begin{array}{r}134 \\
148 \\
45 \\
57\end{array}$ & $\begin{array}{r}227 \\
150 \\
126 \\
47\end{array}$ & $\begin{array}{r}172 \\
180 \\
111 \\
29\end{array}$ & $\begin{array}{r}115 \\
19 \\
42 \\
41\end{array}$ & $\begin{array}{r}117 \\
16 \\
39 \\
41\end{array}$ & $\begin{array}{r}239 \\
84 \\
80 \\
87\end{array}$ & $\begin{array}{r}258 \\
77 \\
143 \\
53\end{array}$ \\
\hline \multicolumn{12}{|c|}{ All Stocks, 1972 to 1976} \\
\hline $\begin{array}{l}\text { Entire } \\
\text { Sim. GBM } \\
\tau(\searrow) \\
\tau(r)\end{array}$ & $\begin{array}{c}59,915 \\
59,915 \\
- \\
-\end{array}$ & $\begin{array}{r}152 \\
75 \\
64 \\
54\end{array}$ & $\begin{array}{r}162 \\
85 \\
55 \\
62\end{array}$ & $\begin{array}{r}82 \\
183 \\
16 \\
42\end{array}$ & $\begin{array}{r}93 \\
154 \\
23 \\
\therefore \quad 50\end{array}$ & $\begin{array}{r}165 \\
156 \\
88 \\
32\end{array}$ & $\begin{array}{r}136 \\
178 \\
78 \\
21\end{array}$ & $\begin{array}{r}171 \\
16 \\
60 \\
61\end{array}$ & $\begin{array}{r}182 \\
10 \\
64 \\
67\end{array}$ & $\begin{array}{r}218 \\
70 \\
53 \\
80\end{array}$ & $\begin{array}{r}223 \\
71 \\
97 \\
59\end{array}$ \\
\hline \multicolumn{12}{|c|}{ All Stocks, 1977 to 1981} \\
\hline $\begin{array}{l}\text { Entire } \\
\text { Sirn. GBM } \\
\tau(\searrow) \\
\tau(r)\end{array}$ & $\begin{array}{c}62,133 \\
62,133 \\
- \\
-\end{array}$ & $\begin{array}{r}223 \\
83 \\
114 \\
56\end{array}$ & $\begin{array}{r}206 \\
88 \\
61 \\
93\end{array}$ & $\begin{array}{r}134 \\
245 \\
24 \\
78\end{array}$ & $\begin{array}{r}110 \\
200 \\
39 \\
44\end{array}$ & $\begin{array}{r}188 \\
188 \\
100 \\
35\end{array}$ & $\begin{array}{r}167 \\
210 \\
97 \\
36\end{array}$ & $\begin{array}{r}146 \\
18 \\
54 \\
53\end{array}$ & $\begin{array}{r}182 \\
12 \\
60 \\
71\end{array}$ & $\begin{array}{r}274 \\
90 \\
82 \\
113\end{array}$ & $\begin{array}{r}290 \\
115 \\
140 \\
76\end{array}$ \\
\hline \multicolumn{12}{|c|}{ All Stocks, 1982 to 1986} \\
\hline $\begin{array}{l}\text { Entire } \\
\text { Sirn. GBM } \\
\tau(\searrow) \\
\tau(\Lambda)\end{array}$ & $\begin{array}{c}61,984 \\
61,984 \\
- \\
-\end{array}$ & $\begin{array}{r}242 \\
115 \\
101 \\
89\end{array}$ & $\begin{array}{r}256 \\
120 \\
104 \\
94\end{array}$ & $\begin{array}{r}106 \\
188 \\
28 \\
51\end{array}$ & $\begin{array}{r}108 \\
144 \\
30 \\
62\end{array}$ & $\begin{array}{r}182 \\
152 \\
93 \\
46\end{array}$ & $\begin{array}{r}190 \\
169 \\
104 \\
40\end{array}$ & $\begin{array}{r}182 \\
31 \\
70 \\
73\end{array}$ & $\begin{array}{r}207 \\
23 \\
95 \\
68\end{array}$ & $\begin{array}{r}313 \\
99 \\
109 \\
116\end{array}$ & $\begin{array}{r}299 \\
87 \\
124 \\
85\end{array}$ \\
\hline \multicolumn{12}{|c|}{ All Stocks, 1987 to 1991} \\
\hline $\begin{array}{l}\text { Entire } \\
\text { Sirn. GBM } \\
\tau(\searrow) \\
\tau(\lambda)\end{array}$ & $\begin{array}{c}61,780 \\
61,780 \\
- \\
-\end{array}$ & $\begin{array}{r}240 \\
68 \\
95 \\
81\end{array}$ & $\begin{array}{r}241 \\
79 \\
89 \\
79\end{array}$ & $\begin{array}{r}104 \\
168 \\
16 \\
68\end{array}$ & $\begin{array}{r}98 \\
132 \\
30 \\
43\end{array}$ & $\begin{array}{r}180 \\
131 \\
86 \\
53\end{array}$ & $\begin{array}{r}169 \\
150 \\
101 \\
36\end{array}$ & $\begin{array}{r}260 \\
11 \\
103 \\
73\end{array}$ & $\begin{array}{r}259 \\
10 \\
102 \\
87\end{array}$ & $\begin{array}{r}287 \\
76 \\
105 \\
100\end{array}$ & $\begin{array}{r}285 \\
68 \\
137 \\
68\end{array}$ \\
\hline \multicolumn{12}{|c|}{ All Stocks, 1992 to 1996} \\
\hline $\begin{array}{l}\text { Entire } \\
\text { Sim. GBM } \\
\tau(\searrow) \\
\tau(\lambda)\end{array}$ & $\begin{array}{c}62,191 \\
62,191 \\
= \\
-\end{array}$ & $\begin{array}{r}299 \\
88 \\
109 \\
106\end{array}$ & $\begin{array}{r}336 \\
78 \\
132 \\
105\end{array}$ & $\begin{array}{r}102 \\
132 \\
17 \\
58\end{array}$ & $\begin{array}{r}102 \\
124 \\
24 \\
42\end{array}$ & $\begin{array}{r}173 \\
143 \\
80 \\
50\end{array}$ & $\begin{array}{r}194 \\
150 \\
110 \\
35\end{array}$ & $\begin{array}{r}292 \\
18 \\
123 \\
92\end{array}$ & $\begin{array}{r}315 \\
26 \\
136 \\
96\end{array}$ & $\begin{array}{r}389 \\
56 \\
149 \\
143\end{array}$ & $\begin{array}{r}368 \\
88 \\
145 \\
104\end{array}$ \\
\hline
\end{tabular}




\section{Table II}

Frequency counts for 10 technical indicators detected among NASDAQ stocks from 1962 to 1996, in 5-year subperiods, in size quintiles, and in a sample of simulated geometric Brownian motion. In each 5-year subperiod, 10 stocks per quintile are selected at random among stocks with at least $80 \%$ non-missing prices, and each stock's price history is scanned for any occurrence of the following 10 technical indicators within the subperiod: head-and-shoulders (HS), inverted headand-shoulders (IHS), broadening top (BTOP), broadening bottom (BBOT), triangle top (TTOP), triangle bottom (TBOT), rectangle top (RTOP), rectangle bottom (RBOT), double top (DTOP), and double bottom (DBOT). The 'Sample' column indicates whether the frequency counts are conditioned on decreasing volume trend (' $\tau(\chi)$ '), increasing volume trend (' $\tau(\chi)$ '), unconditional ('Entire'), or for a sample of simulated geometric Brownian motion with parameters calibrated to match the data ('Sim. GBM').

\begin{tabular}{|c|c|c|c|c|c|c|c|c|c|c|c|}
\hline Sample & Raw & HS & IHS & BTOP & BBOT & TTOP & ТВOT & RTOP & RBOT & DTOP & DBOT \\
\hline \multicolumn{12}{|c|}{ All Stocks, 1962 to 1996} \\
\hline $\begin{array}{l}\text { Entire } \\
\text { Sim. GBM } \\
\tau(y) \\
\tau(x)\end{array}$ & $\begin{array}{c}411,010 \\
411,010 \\
-\end{array}$ & $\begin{array}{l}919 \\
434 \\
408 \\
284\end{array}$ & $\begin{array}{l}817 \\
447 \\
268 \\
325\end{array}$ & $\begin{array}{r}414 \\
1297 \\
69 \\
234\end{array}$ & $\begin{array}{r}508 \\
1139 \\
133 \\
209\end{array}$ & $\begin{array}{r}850 \\
1169 \\
429 \\
185\end{array}$ & $\begin{array}{r}789 \\
1309 \\
460 \\
125\end{array}$ & $\begin{array}{r}1134 \\
96 \\
488 \\
391\end{array}$ & $\begin{array}{r}1320 \\
91 \\
550 \\
461\end{array}$ & $\begin{array}{r}1208 \\
567 \\
339 \\
474\end{array}$ & $\begin{array}{r}1147 \\
579 \\
580 \\
229\end{array}$ \\
\hline \multicolumn{12}{|c|}{ Smallest Quintile, 1962 to 1996} \\
\hline $\begin{array}{l}\text { Entire } \\
\text { Sim. GBM } \\
\tau(x) \\
\tau(x)\end{array}$ & $\begin{array}{c}81,754 \\
81,754 \\
- \\
-\end{array}$ & $\begin{array}{l}84 \\
85 \\
36 \\
31\end{array}$ & $\begin{array}{l}64 \\
84 \\
25 \\
23\end{array}$ & $\begin{array}{r}41 \\
341 \\
6 \\
31\end{array}$ & $\begin{array}{r}73 \\
289 \\
20 \\
30\end{array}$ & $\begin{array}{c}111 \\
334 \\
56 \\
24\end{array}$ & $\begin{array}{r}93 \\
367 \\
59 \\
15\end{array}$ & $\begin{array}{r}165 \\
11 \\
77 \\
59\end{array}$ & $\begin{array}{r}218 \\
12 \\
102 \\
85\end{array}$ & $\begin{array}{r}113 \\
140 \\
31 \\
46\end{array}$ & $\begin{array}{r}125 \\
125 \\
81 \\
17\end{array}$ \\
\hline \multicolumn{12}{|c|}{ 2nd Quintile, 1962 to 1996} \\
\hline $\begin{array}{l}\text { Entire } \\
\text { Sim. GBM } \\
\tau(y) \\
\tau(x)\end{array}$ & $\begin{array}{c}81,336 \\
81,336 \\
- \\
-\end{array}$ & $\begin{array}{r}191 \\
67 \\
94 \\
66\end{array}$ & $\begin{array}{r}138 \\
84 \\
51 \\
57\end{array}$ & $\begin{array}{r}68 \\
243 \\
11 \\
46\end{array}$ & $\begin{array}{r}88 \\
225 \\
28 \\
38\end{array}$ & $\begin{array}{r}161 \\
219 \\
86 \\
45\end{array}$ & $\begin{array}{r}148 \\
229 \\
109 \\
22\end{array}$ & $\begin{array}{r}242 \\
24 \\
111 \\
85\end{array}$ & $\begin{array}{r}305 \\
12 \\
131 \\
120\end{array}$ & $\begin{array}{r}219 \\
99 \\
69 \\
90\end{array}$ & $\begin{array}{r}176 \\
124 \\
101 \\
42\end{array}$ \\
\hline \multicolumn{12}{|c|}{ 3rd Quintile, 1962 to 1996} \\
\hline $\begin{array}{l}\text { Entire } \\
\text { Sim. GBM } \\
\tau(y) \\
\tau(r)\end{array}$ & $\begin{array}{c}81,772 \\
81,772 \\
- \\
-\end{array}$ & $\begin{array}{r}224 \\
69 \\
108 \\
71\end{array}$ & $\begin{array}{r}186 \\
86 \\
66 \\
79\end{array}$ & $\begin{array}{r}105 \\
227 \\
23 \\
56\end{array}$ & $\begin{array}{r}121 \\
210 \\
35 \\
49\end{array}$ & $\begin{array}{r}183 \\
214 \\
87 \\
39\end{array}$ & $\begin{array}{r}155 \\
239 \\
91 \\
29\end{array}$ & $\begin{array}{r}235 \\
15 \\
.90 \\
84\end{array}$ & $\begin{array}{r}244 \\
14 \\
84 \\
86\end{array}$ & $\begin{array}{r}279 \\
105 \\
78 \\
122\end{array}$ & $\begin{array}{r}267 \\
100 \\
145 \\
58\end{array}$ \\
\hline \multicolumn{12}{|c|}{ 4th Quintile, 1962 to 1996} \\
\hline $\begin{array}{l}\text { Entire } \\
\text { Sim. GBM } \\
\tau(y) \\
\tau(x)\end{array}$ & $\begin{array}{c}82,727 \\
82,727 \\
- \\
-\end{array}$ & $\begin{array}{r}212 \\
104 \\
88 \\
62\end{array}$ & $\begin{array}{r}214 \\
92 \\
68 \\
83\end{array}$ & $\begin{array}{r}92 \\
242 \\
12 \\
57\end{array}$ & $\begin{array}{r}116 \\
219 \\
26 \\
56\end{array}$ & $\begin{array}{r}187 \\
209 \\
101 \\
34\end{array}$ & $\begin{array}{r}179 \\
255 \\
101 \\
22\end{array}$ & $\begin{array}{r}296 \\
23 \\
127 \\
104\end{array}$ & $\begin{array}{r}303 \\
26 \\
141 \\
93\end{array}$ & $\begin{array}{r}289 \\
115 \\
77 \\
118\end{array}$ & $\begin{array}{r}297 \\
97 \\
143 \\
66\end{array}$ \\
\hline \multicolumn{12}{|c|}{ Largest Quintile, 1962 to 1996} \\
\hline $\begin{array}{l}\text { Entire } \\
\text { Sim. GBM } \\
\tau(\nu) \\
\tau(r)\end{array}$ & $\begin{array}{l}83,421 \\
83,421 \\
- \\
-\end{array}$ & $\begin{array}{r}208 \\
109 \\
82 \\
54\end{array}$ & $\begin{array}{r}215 \\
101 \\
58 \\
83\end{array}$ & $\begin{array}{r}108 \\
244 \\
17 \\
44\end{array}$ & $\begin{array}{r}110 \\
196 \\
24 \\
36\end{array}$ & $\begin{array}{r}208 \\
193 \\
99 \\
43\end{array}$ & $\begin{array}{r}214 \\
219 \\
100 \\
37\end{array}$ & $\begin{array}{r}196 \\
23 \\
83 \\
59\end{array}$ & $\begin{array}{r}250 \\
27 \\
92 \\
77\end{array}$ & $\begin{array}{r}308 \\
108 \\
84 \\
98\end{array}$ & $\begin{array}{r}282 \\
133 \\
110 \\
46\end{array}$ \\
\hline
\end{tabular}


Table II (continued)

\begin{tabular}{|c|c|c|c|c|c|c|c|c|c|c|c|}
\hline Sample & Raw & HS & IHS & BTOP & BBOT & TTOP & TBOT & RTOP & RBOT & DTOP & DBOT \\
\hline \multicolumn{12}{|c|}{ All Stocks, 1962 to 1966} \\
\hline $\begin{array}{l}\text { Entire } \\
\text { Sim. GBM } \\
\tau(\searrow) \\
\tau(\nearrow)\end{array}$ & $\begin{array}{c}55,969 \\
55,969 \\
- \\
-\end{array}$ & $\begin{array}{r}274 \\
69 \\
129 \\
83\end{array}$ & $\begin{array}{r}268 \\
63 \\
99 \\
103\end{array}$ & $\begin{array}{r}72 \\
163 \\
10 \\
48\end{array}$ & $\begin{array}{r}99 \\
123 \\
23 \\
51\end{array}$ & $\begin{array}{r}182 \\
137 \\
104 \\
37\end{array}$ & $\begin{array}{r}144 \\
149 \\
98 \\
23\end{array}$ & $\begin{array}{r}288 \\
24 \\
115 \\
101\end{array}$ & $\begin{array}{r}329 \\
22 \\
136 \\
116\end{array}$ & $\begin{array}{r}326 \\
77 \\
96 \\
144\end{array}$ & $\begin{array}{r}342 \\
90 \\
210 \\
64\end{array}$ \\
\hline \multicolumn{12}{|c|}{ All Stocks, 1967 to 1971} \\
\hline $\begin{array}{l}\text { Entire } \\
\text { Sim. GBM } \\
\tau(y) \\
\tau(\nearrow)\end{array}$ & $\begin{array}{c}60,563 \\
60,563 \\
- \\
-\end{array}$ & $\begin{array}{r}115 \\
58 \\
61 \\
24\end{array}$ & $\begin{array}{r}120 \\
61 \\
29 \\
57\end{array}$ & $\begin{array}{r}104 \\
194 \\
15 \\
71\end{array}$ & $\begin{array}{r}123 \\
184 \\
40 \\
51\end{array}$ & $\begin{array}{r}227 \\
181 \\
127 \\
45\end{array}$ & $\begin{array}{r}171 \\
188 \\
123 \\
19\end{array}$ & $\begin{array}{r}65 \\
9 \\
26 \\
25\end{array}$ & $\begin{array}{r}83 \\
8 \\
39 \\
16\end{array}$ & $\begin{array}{r}196 \\
90 \\
49 \\
86\end{array}$ & $\begin{array}{r}200 \\
83 \\
137 \\
17\end{array}$ \\
\hline \multicolumn{12}{|c|}{ All Stocks, 1972 to 1976} \\
\hline $\begin{array}{l}\text { Entire } \\
\text { Sim. GBM } \\
\tau(\searrow) \\
\tau(\nearrow)\end{array}$ & $\begin{array}{c}51,446 \\
51,446 \\
- \\
-\end{array}$ & $\begin{array}{r}34 \\
32 \\
5 \\
8\end{array}$ & $\begin{array}{r}30 \\
37 \\
4 \\
7\end{array}$ & $\begin{array}{r}14 \\
115 \\
0 \\
1\end{array}$ & $\begin{array}{r}30 \\
113 \\
4 \\
2\end{array}$ & $\begin{array}{r}29 \\
107 \\
5 \\
2\end{array}$ & $\begin{array}{r}28 \\
110 \\
7 \\
0\end{array}$ & $\begin{array}{r}51 \\
5 \\
12 \\
5\end{array}$ & $\begin{array}{r}55 \\
6 \\
8 \\
12\end{array}$ & $\begin{array}{r}55 \\
46 \\
3 \\
8\end{array}$ & $\begin{array}{r}58 \\
46 \\
8 \\
3\end{array}$ \\
\hline \multicolumn{12}{|c|}{ All Stocks, 1977 to 1981} \\
\hline $\begin{array}{l}\text { Entire } \\
\text { Sim. GBM } \\
\tau(\searrow) \\
\tau(\nearrow)\end{array}$ & $\begin{array}{c}61,972 \\
61,972 \\
- \\
-\end{array}$ & $\begin{array}{r}56 \\
90 \\
7 \\
6\end{array}$ & $\begin{array}{r}53 \\
84 \\
7 \\
6\end{array}$ & $\begin{array}{r}41 \\
236 \\
1 \\
5\end{array}$ & $\begin{array}{r}36 \\
165 \\
2 \\
1\end{array}$ & $\begin{array}{r}52 \\
176 \\
4 \\
4\end{array}$ & $\begin{array}{r}73 \\
212 \\
8 \\
0\end{array}$ & $\begin{array}{r}57 \\
19 \\
12 \\
5\end{array}$ & $\begin{array}{r}65 \\
19 \\
12 \\
8\end{array}$ & $\begin{array}{r}89 \\
110 \\
7 \\
7\end{array}$ & $\begin{array}{r}96 \\
98 \\
9 \\
6\end{array}$ \\
\hline \multicolumn{12}{|c|}{ All Stocks, 1982 to 1986} \\
\hline $\begin{array}{l}\text { Entire } \\
\text { Sim. GBM } \\
\tau(y) \\
\tau(y)\end{array}$ & $\begin{array}{c}61,110 \\
61,110 \\
- \\
-\end{array}$ & $\begin{array}{l}71 \\
86 \\
37 \\
21\end{array}$ & $\begin{array}{l}64 \\
90 \\
19 \\
25\end{array}$ & $\begin{array}{r}46 \\
162 \\
8 \\
24\end{array}$ & $\begin{array}{r}44 \\
168 \\
14 \\
18\end{array}$ & $\begin{array}{r}97 \\
147 \\
\cdot 46 \\
26\end{array}$ & $\begin{array}{r}107 \\
174 \\
58 \\
22\end{array}$ & $\begin{array}{r}109 \\
23 \\
45 \\
42\end{array}$ & $\begin{array}{r}115 \\
21 \\
52 \\
42\end{array}$ & $\begin{array}{r}120 \\
97 \\
40 \\
38\end{array}$ & $\begin{array}{l}97 \\
98 \\
48 \\
24\end{array}$ \\
\hline \multicolumn{12}{|c|}{ All Stocks, 1987 to 1991} \\
\hline $\begin{array}{l}\text { Entire } \\
\text { Sim. GBM } \\
\tau(y) \\
\tau(\nearrow)\end{array}$ & $\begin{array}{c}60,862 \\
60,862 \\
- \\
-\end{array}$ & $\begin{array}{r}158 \\
59 \\
79 \\
58\end{array}$ & $\begin{array}{r}120 \\
57 \\
46 \\
56\end{array}$ & $\begin{array}{r}50 \\
229 \\
11 \\
33\end{array}$ & $\begin{array}{r}61 \\
187 \\
19 \\
30\end{array}$ & $\begin{array}{r}120 \\
205 \\
73 \\
26\end{array}$ & $\begin{array}{r}109 \\
244 \\
69 \\
28\end{array}$ & $\begin{array}{r}265 \\
7 \\
130 \\
100\end{array}$ & $\begin{array}{r}312 \\
7 \\
140 \\
122\end{array}$ & $\begin{array}{r}177 \\
79 \\
50 \\
89\end{array}$ & $\begin{array}{r}155 \\
88 \\
69 \\
55\end{array}$ \\
\hline \multicolumn{12}{|c|}{ All Stocks, 1992 to 1996} \\
\hline $\begin{array}{l}\text { Entire } \\
\text { Sim. GBM } \\
\tau(y) \\
\tau(r)\end{array}$ & $\begin{array}{c}59,088 \\
59,088 \\
- \\
-\end{array}$ & $\begin{array}{r}211 \\
40 \\
90 \\
84\end{array}$ & $\begin{array}{r}162 \\
55 \\
64 \\
71\end{array}$ & $\begin{array}{r}87 \\
198 \\
24 \\
52\end{array}$ & $\begin{array}{r}115 \\
199 \\
31 \\
56\end{array}$ & $\begin{array}{r}143 \\
216 \\
70 \\
45\end{array}$ & $\begin{array}{r}157 \\
232 \\
97 \\
33\end{array}$ & $\begin{array}{r}299 \\
9 \\
148 \\
113\end{array}$ & $\begin{array}{r}361 \\
8 \\
163 \\
145\end{array}$ & $\begin{array}{r}245 \\
68 \\
94 \\
102\end{array}$ & $\begin{array}{r}199 \\
76 \\
99 \\
60\end{array}$ \\
\hline
\end{tabular}




\section{Table III}

Summary statistics (mean, standard deviation, skewness, and excess kurtosis) of raw and condjtional 1-day normalized returns of NYSE/AMEX stocks from 1962 to 1996, in 5-year subperiods, and in size quintiles. Conditional returns are defined as the daily return three days following the conclusion of an occurrence of one of 10 technical indicators: head-and-shoulders (HS), inverted head-and-shoulders (IHS), broadening top (BTOP), broadening bottom (BBOT), triangle top (TTOP), triangle bottom (TBOT), rectangle top (RTOP), rectangle bottom (RBOT), double top (DTOP), and double bottom (DBOT). All returns have been normalized by subtraction of their means and division by their standard deviations.

\begin{tabular}{|c|c|c|c|c|c|c|c|c|c|c|c|}
\hline Moment & Raw & HS & IHS & BTOP & BBOT & TTOP & TBOT & RTOP & RBOT & DTOP & DBOT \\
\hline \multicolumn{12}{|c|}{ All Stocks, 1962 to 1996} \\
\hline $\begin{array}{l}\text { Mean } \\
\text { S.D. } \\
\text { Skew } \\
\text { Kurt }\end{array}$ & $\begin{array}{r}-0.000 \\
1.000 \\
0.345 \\
8.122\end{array}$ & $\begin{array}{r}-0.038 \\
0.867 \\
0.135 \\
2.428\end{array}$ & $\begin{array}{l}0.040 \\
0.937 \\
0.660 \\
4.527\end{array}$ & $\begin{array}{r}-0.005 \\
1.035 \\
-1.151 \\
16.701\end{array}$ & $\begin{array}{r}-0.062 \\
0.979 \\
0.090 \\
3.169\end{array}$ & $\begin{array}{l}0.021 \\
0.955 \\
0.137 \\
3.293\end{array}$ & $\begin{array}{r}-0.009 \\
0.959 \\
0.643 \\
7.061\end{array}$ & $\begin{array}{r}0.009 \\
0.865 \\
-0.420 \\
7.360\end{array}$ & $\begin{array}{l}0.014 \\
0.883 \\
0.110 \\
4.194\end{array}$ & $\begin{array}{l}0.017 \\
0.910 \\
0.206 \\
3.386\end{array}$ & $\begin{array}{r}-0.001 \\
0.999 \\
0.460 \\
7.374\end{array}$ \\
\hline \multicolumn{12}{|c|}{ Smallest Quintile, 1962 to 1996} \\
\hline $\begin{array}{l}\text { Mean } \\
\text { S.D. } \\
\text { Skew } \\
\text { Kurt }\end{array}$ & $\begin{array}{r}-0.000 \\
1.000 \\
0.697 \\
10.873\end{array}$ & $\begin{array}{r}-0.014 \\
0.854 \\
0.802 \\
3.870\end{array}$ & $\begin{array}{l}0.036 \\
1.002 \\
1.337 \\
7.143\end{array}$ & $\begin{array}{r}-0.093 \\
0.940 \\
-1.771 \\
6.701\end{array}$ & $\begin{array}{r}-0.188 \\
0.850 \\
-0.367 \\
0.575\end{array}$ & $\begin{array}{l}0.036 \\
0.937 \\
0.861 \\
4.185\end{array}$ & $\begin{array}{r}-0.020 \\
1.157 \\
2.592 \\
12.532\end{array}$ & $\begin{array}{r}0.037 \\
0.833 \\
-0.187 \\
1.793\end{array}$ & $\begin{array}{r}-0.093 \\
0.986 \\
0.445 \\
4.384\end{array}$ & $\begin{array}{l}0.043 \\
0.950 \\
0.511 \\
2.581\end{array}$ & $\begin{array}{r}-0.055 \\
0.962 \\
0.002 \\
3.989\end{array}$ \\
\hline \multicolumn{12}{|c|}{ 2nd Quintile, 1962 to 1996} \\
\hline $\begin{array}{l}\text { Mean } \\
\text { S.D. } \\
\text { Skew } \\
\text { Kurt }\end{array}$ & $\begin{array}{r}-0.000 \\
1.000 \\
0.392 \\
7.836\end{array}$ & $\begin{array}{r}-0.069 \\
0.772 \\
0.223 \\
0.657\end{array}$ & $\begin{array}{l}0.144 \\
1.031 \\
1.128 \\
6.734\end{array}$ & $\begin{array}{r}0.061 \\
1.278 \\
-3.296 \\
32.750\end{array}$ & $\begin{array}{r}-0.113 \\
1.004 \\
0.485 \\
3.779\end{array}$ & $\begin{array}{r}0.003 \\
0.913 \\
-0.529 \\
3.024\end{array}$ & $\begin{array}{l}0.035 \\
0.965 \\
0.166 \\
4.987\end{array}$ & $\begin{array}{r}0.018 \\
0.979 \\
-1.375 \\
17.040\end{array}$ & $\begin{array}{l}0.019 \\
0.868 \\
0.452 \\
3.914\end{array}$ & $\begin{array}{l}0.067 \\
0.776 \\
0.392 \\
2.151\end{array}$ & $\begin{array}{r}-0.011 \\
1.069 \\
1.728 \\
15.544\end{array}$ \\
\hline \multicolumn{12}{|c|}{ 3rd Quintile, 1962 to 1996} \\
\hline $\begin{array}{l}\text { Mean } \\
\text { S.D. } \\
\text { Skew } \\
\text { Kurt }\end{array}$ & $\begin{array}{r}-0.000 \\
1.000 \\
0.246 \\
7.466\end{array}$ & $\begin{array}{r}-0.048 \\
0.888 \\
-0.465 \\
3.239\end{array}$ & $\begin{array}{r}-0.043 \\
0.856 \\
0.107 \\
1.612\end{array}$ & $\begin{array}{r}-0.076 \\
0.894 \\
-0.023 \\
1.024\end{array}$ & $\begin{array}{r}-0.056 \\
0.925 \\
0.233 \\
0.611\end{array}$ & $\begin{array}{l}0.036 \\
0.973 \\
0.538 \\
2.995\end{array}$ & $\begin{array}{l}0.012 \\
0.796 \\
0.166 \\
0.586\end{array}$ & $\begin{array}{l}0.075 \\
0.798 \\
0.678 \\
3.010\end{array}$ & $\begin{array}{r}0.028 \\
0.892 \\
-0.618 \\
4.769\end{array}$ & $\begin{array}{r}-0.039 \\
0.956 \\
0.013 \\
4.517\end{array}$ & $\begin{array}{r}-0.034 \\
1.026 \\
-0.242 \\
3.663\end{array}$ \\
\hline \multicolumn{12}{|c|}{ 4th Quintile, 1962 to 1996} \\
\hline $\begin{array}{l}\text { Mean } \\
\text { S.D. } \\
\text { Skew } \\
\text { Kurt }\end{array}$ & $\begin{array}{r}-0.000 \\
1.000 \\
0.222 \\
6.452\end{array}$ & $\begin{array}{r}-0.012 \\
0.964 \\
0.055 \\
1.444\end{array}$ & $\begin{array}{l}0.022 \\
0.903 \\
0.592 \\
1.745\end{array}$ & $\begin{array}{l}0.115 \\
0.990 \\
0.458 \\
1.251\end{array}$ & $\begin{array}{l}0.028 \\
1.093 \\
0.537 \\
2.168\end{array}$ & $\begin{array}{r}0.022 \\
0.986 \\
-0.217 \\
4.237\end{array}$ & $\begin{array}{r}-0.014 \\
0.959 \\
-0.456 \\
8.324\end{array}$ & $\begin{array}{r}-0.113 \\
0.854 \\
-0.415 \\
4.311\end{array}$ & $\begin{array}{l}0.065 \\
0.821 \\
0.820 \\
3.632\end{array}$ & $\begin{array}{l}0.015 \\
0.858 \\
0.550 \\
1.719\end{array}$ & $\begin{array}{r}-0.006 \\
0.992 \\
-0.062 \\
4.691\end{array}$ \\
\hline \multicolumn{12}{|c|}{ Largest Quintile, 1962 to 1996} \\
\hline $\begin{array}{l}\text { Mean } \\
\text { S.D. } \\
\text { Skew } \\
\text { Kurt }\end{array}$ & $\begin{array}{r}-0.000 \\
1.000 \\
0.174 \\
7.992\end{array}$ & $\begin{array}{r}-0.038 \\
0.843 \\
0.438 \\
2.621\end{array}$ & $\begin{array}{l}0.054 \\
0.927 \\
0.182 \\
3.465\end{array}$ & $\begin{array}{r}-0.081 \\
0.997 \\
0.470 \\
3.275\end{array}$ & $\begin{array}{r}-0.042 \\
0.951 \\
-1.099 \\
6.603\end{array}$ & $\begin{array}{l}0.010 \\
0.964 \\
0.089 \\
2.107\end{array}$ & $\begin{array}{r}-0.049 \\
0.965 \\
0.357 \\
2.509\end{array}$ & $\begin{array}{r}0.009 \\
0.850 \\
-0.167 \\
0.816\end{array}$ & $\begin{array}{r}0.060 \\
0.820 \\
-0.140 \\
3.179\end{array}$ & $\begin{array}{l}0.018 \\
0.971 \\
0.011 \\
3.498\end{array}$ & $\begin{array}{l}0.067 \\
0.941 \\
0.511 \\
5.035\end{array}$ \\
\hline
\end{tabular}


Table III (continued)

\begin{tabular}{|c|c|c|c|c|c|c|c|c|c|c|c|}
\hline Moment & Raw & HS & IHS & BTOP & BBOT & TTOP & TВOT & RTOP & RBOT & DTOP & DBOT \\
\hline \multicolumn{12}{|c|}{ All Stocks, 1962 to 1966} \\
\hline $\begin{array}{l}\text { Mean } \\
\text { S.D. } \\
\text { Skew } \\
\text { Kurt }\end{array}$ & $\begin{array}{r}-0.000 \\
1.000 \\
0.563 \\
9.161\end{array}$ & $\begin{array}{l}0.070 \\
0.797 \\
0.159 \\
0.612\end{array}$ & $\begin{array}{l}0.090 \\
0.925 \\
0.462 \\
1.728\end{array}$ & $\begin{array}{l}0.159 \\
0.825 \\
0.363 \\
0.657\end{array}$ & $\begin{array}{l}0.079 \\
1.085 \\
1.151 \\
5.063\end{array}$ & $\begin{array}{r}-0.033 \\
1.068 \\
-0.158 \\
2.674\end{array}$ & $\begin{array}{r}-0.039 \\
1.011 \\
1.264 \\
4.826\end{array}$ & $\begin{array}{r}-0.041 \\
0.961 \\
-1.337 \\
17.161\end{array}$ & $\begin{array}{r}0.019 \\
0.814 \\
-0.341 \\
1.400\end{array}$ & $\begin{array}{r}-0.071 \\
0.859 \\
-0.427 \\
3.416\end{array}$ & $\begin{array}{r}-0.100 \\
0.962 \\
-0.876 \\
5.622\end{array}$ \\
\hline \multicolumn{12}{|c|}{ All Stocks, 1967 to 1971} \\
\hline $\begin{array}{l}\text { Mean } \\
\text { S.D. } \\
\text { Skew } \\
\text { Kurt }\end{array}$ & $\begin{array}{r}-0.000 \\
1.000 \\
0.342 \\
5.810\end{array}$ & $\begin{array}{r}-0.044 \\
0.809 \\
0.754 \\
3.684\end{array}$ & $\begin{array}{l}0.079 \\
0.944 \\
0.666 \\
2.725\end{array}$ & $\begin{array}{r}-0.035 \\
0.793 \\
0.304 \\
0.706\end{array}$ & $\begin{array}{r}-0.056 \\
0.850 \\
0.085 \\
0.141\end{array}$ & $\begin{array}{l}0.025 \\
0.885 \\
0.650 \\
3.099\end{array}$ & $\begin{array}{l}0.057 \\
0.886 \\
0.697 \\
1.659\end{array}$ & $\begin{array}{r}-0.101 \\
0.831 \\
-1.393 \\
8.596\end{array}$ & $\begin{array}{l}0.110 \\
0.863 \\
0.395 \\
3.254\end{array}$ & $\begin{array}{l}0.093 \\
1.083 \\
1.360 \\
4.487\end{array}$ & $\begin{array}{l}0.079 \\
0.835 \\
0.701 \\
1.853\end{array}$ \\
\hline \multicolumn{12}{|c|}{ All Stocks, 1972 to 1976} \\
\hline $\begin{array}{l}\text { Mean } \\
\text { S.D. } \\
\text { Skew } \\
\text { Kurt }\end{array}$ & $\begin{array}{r}-0.000 \\
1.000 \\
0.316 \\
6.520\end{array}$ & $\begin{array}{r}-0.035 \\
1.015 \\
-0.334 \\
2.286\end{array}$ & $\begin{array}{l}0.043 \\
0.810 \\
0.717 \\
1.565\end{array}$ & $\begin{array}{r}0.101 \\
0.985 \\
-0.699 \\
6.562\end{array}$ & $\begin{array}{r}-0.138 \\
0.918 \\
0.272 \\
1.453\end{array}$ & $\begin{array}{r}-0.045 \\
0.945 \\
-1.014 \\
5.261\end{array}$ & $\begin{array}{r}-0.010 \\
0.922 \\
0.676 \\
4.912\end{array}$ & $\begin{array}{r}-0.025 \\
0.870 \\
0.234 \\
3.627\end{array}$ & $\begin{array}{r}-0.003 \\
0.754 \\
0.199 \\
2.337\end{array}$ & $\begin{array}{r}-0.051 \\
0.914 \\
0.056 \\
3.520\end{array}$ & $\begin{array}{r}-0.108 \\
0.903 \\
-0.366 \\
5.047\end{array}$ \\
\hline \multicolumn{12}{|c|}{ All Stocks, 1977 to 1981} \\
\hline $\begin{array}{l}\text { Mean } \\
\text { S.D. } \\
\text { Skew } \\
\text { Kurt }\end{array}$ & $\begin{array}{r}-0.000 \\
1.000 \\
0.466 \\
6.419\end{array}$ & $\begin{array}{r}-0.138 \\
0.786 \\
-0.304 \\
1.132\end{array}$ & $\begin{array}{r}-0.040 \\
0.863 \\
0.052 \\
1.048\end{array}$ & $\begin{array}{l}0.076 \\
1.015 \\
1.599 \\
4.961\end{array}$ & $\begin{array}{r}-0.114 \\
0.989 \\
-0.033 \\
-0.125\end{array}$ & $\begin{array}{l}0.135 \\
1.041 \\
0.776 \\
2.964\end{array}$ & $\begin{array}{r}-0.050 \\
1.011 \\
0.110 \\
0.989\end{array}$ & $\begin{array}{r}-0.004 \\
0.755 \\
-0.084 \\
1.870\end{array}$ & $\begin{array}{l}0.026 \\
0.956 \\
0.534 \\
2.184\end{array}$ & $\begin{array}{l}0.042 \\
0.827 \\
0.761 \\
2.369\end{array}$ & $\begin{array}{r}0.178 \\
1.095 \\
2.214 \\
15.290\end{array}$ \\
\hline \multicolumn{12}{|c|}{ All Stocks, 1982 to 1986} \\
\hline $\begin{array}{l}\text { Mean } \\
\text { S.D. } \\
\text { Skew } \\
\text { Kurt. }\end{array}$ & $\begin{array}{r}-0.000 \\
1.000 \\
0.460 \\
6.799\end{array}$ & $\begin{array}{r}-0.099 \\
0.883 \\
0.464 \\
2.280\end{array}$ & $\begin{array}{r}-0.007 \\
1.002 \\
0.441 \\
6.128\end{array}$ & $\begin{array}{l}0.011 \\
1.109 \\
0.372 \\
2.566\end{array}$ & $\begin{array}{r}0.095 \\
0.956 \\
-0.165 \\
2.735\end{array}$ & $\begin{array}{r}-0.114 \\
0.924 \\
0.473 \\
3.208\end{array}$ & $\begin{array}{r}-0.067 \\
0.801 \\
-1.249 \\
5.278\end{array}$ & $\begin{array}{l}0.050 \\
0.826 \\
0.231 \\
1.108\end{array}$ & $\begin{array}{l}0.005 \\
0.934 \\
0.467 \\
4.234\end{array}$ & $\begin{array}{l}0.011 \\
0.850 \\
0.528 \\
1.515\end{array}$ & $\begin{array}{r}-0.013 \\
1.026 \\
0.867 \\
7.400\end{array}$ \\
\hline \multicolumn{12}{|c|}{ All Stocks, 1987 to 1991} \\
\hline $\begin{array}{l}\text { Mean } \\
\text { S.D. } \\
\text { Skew } \\
\text { Kurt }\end{array}$ & $\begin{array}{r}-0.000 \\
1.000 \\
-0.018 \\
13.478\end{array}$ & $\begin{array}{r}-0.037 \\
0.848 \\
-0.526 \\
3.835\end{array}$ & $\begin{array}{l}0.033 \\
0.895 \\
0.272 \\
4.395\end{array}$ & $\begin{array}{r}-0.091 \\
0.955 \\
0.108 \\
2.247\end{array}$ & $\begin{array}{r}-0.040 \\
0.818 \\
0.231 \\
1.469\end{array}$ & $\begin{array}{l}0.053 \\
0.857 \\
0.165 \\
4.422\end{array}$ & $\begin{array}{r}0.003 \\
0.981 \\
-1.216 \\
9.586\end{array}$ & $\begin{array}{l}0.040 \\
0.894 \\
0.293 \\
1.646\end{array}$ & $\begin{array}{r}-0.020 \\
0.833 \\
0.124 \\
3.973\end{array}$ & $\begin{array}{r}-0.022 \\
0.873 \\
-1.184 \\
4.808\end{array}$ & $\begin{array}{r}-0.017 \\
1.052 \\
-0.368 \\
4.297\end{array}$ \\
\hline \multicolumn{12}{|c|}{ All Stocks, 1992 to 1996} \\
\hline $\begin{array}{l}\text { Mean } \\
\text { S.D. } \\
\text { Skew } \\
\text { Kurt }\end{array}$ & $\begin{array}{r}-0.000 \\
1.000 \\
0.308 \\
8.683\end{array}$ & $\begin{array}{r}-0.014 \\
0.935 \\
0.545 \\
2.249\end{array}$ & $\begin{array}{l}0.069 \\
1.021 \\
1.305 \\
6.684\end{array}$ & $\begin{array}{r}-0.231 \\
1.406 \\
-3.988 \\
27.022\end{array}$ & $\begin{array}{r}-0.272 \\
1.187 \\
-0.502 \\
3.947\end{array}$ & $\begin{array}{r}0.122 \\
0.953 \\
-0.190 \\
1.235\end{array}$ & $\begin{array}{r}0.041 \\
1.078 \\
2.460 \\
12.883\end{array}$ & $\begin{array}{r}0.082 \\
0.814 \\
-0.167 \\
0.506\end{array}$ & $\begin{array}{r}0.011 \\
0.996 \\
-0.129 \\
6.399\end{array}$ & $\begin{array}{r}0.102 \\
0.960 \\
-0.091 \\
1.507\end{array}$ & $\begin{array}{r}-0.016 \\
1.035 \\
0.379 \\
3.358\end{array}$ \\
\hline
\end{tabular}




\section{Table IV}

Summary statistics (mean, standard deviation, skewness, and excess kurtosis) of raw and conditional 1-day normalized returns of NASDAQ stocks from 1962 to 1996, in 5-year subperiods, and in size quintiles. Conditional returns are defined as the daily return three days following the conclusion of an occurrence of one of 10 technical indicators: head-and-shoulders (HS), inverted headand-shoulders (IHS), broadening top (BTOP), broadening bottom (BBOT), triangle top (TTOP), triangle bottom (TBOT), rectangle top (RTOP), rectangle bottom (RBOT), double top (DTOP), and double bottom (DBOT). All returns have been normalized by subtraction of their means and division by their standard deviations.

\begin{tabular}{|c|c|c|c|c|c|c|c|c|c|c|c|}
\hline Moment & Raw & HS & IHS & BTOP. & BBOT & TTOP & ТВот & RTOP & RBOT & DTOP & DBOT \\
\hline \multicolumn{12}{|c|}{ All Stocks, 1962 to 1996} \\
\hline $\begin{array}{l}\text { Mean } \\
\text { S.D. } \\
\text { Skew } \\
\text { Kurt }\end{array}$ & $\begin{array}{r}0.000 \\
1.000 \\
0.608 \\
12.728\end{array}$ & $\begin{array}{r}-0.016 \\
0.907 \\
-0.017 \\
3.039\end{array}$ & $\begin{array}{l}0.042 \\
0.994 \\
1.290 \\
8.774\end{array}$ & $\begin{array}{r}-0.009 \\
0.960 \\
0.397 \\
3.246\end{array}$ & $\begin{array}{l}0.009 \\
0.995 \\
0.586 \\
2.783\end{array}$ & $\begin{array}{r}-0.020 \\
0.984 \\
0.895 \\
6.692\end{array}$ & $\begin{array}{l}0.017 \\
0.932 \\
0.716 \\
3.844\end{array}$ & $\begin{array}{l}0.052 \\
0.948 \\
0.710 \\
5.173\end{array}$ & $\begin{array}{l}0.043 \\
0.929 \\
0.755 \\
4.368\end{array}$ & $\begin{array}{l}0.003 \\
0.933 \\
0.405 \\
4.150\end{array}$ & $\begin{array}{r}-0.035 \\
0.880 \\
-0.104 \\
2.052\end{array}$ \\
\hline \multicolumn{12}{|c|}{ Smallest Quintile, 1962 to 1996} \\
\hline $\begin{array}{l}\text { Mean } \\
\text { S.D. } \\
\text { Skew } \\
\text { Kurt }\end{array}$ & $\begin{array}{r}-0.000 \\
1.000 \\
0.754 \\
15.859\end{array}$ & $\begin{array}{l}0.018 \\
0.845 \\
0.325 \\
1.096\end{array}$ & $\begin{array}{r}-0.032 \\
1.319 \\
1.756 \\
4.221\end{array}$ & $\begin{array}{r}0.087 \\
0.874 \\
-0.239 \\
1.490\end{array}$ & $\begin{array}{r}-0.153 \\
0.894 \\
-0.109 \\
0.571\end{array}$ & $\begin{array}{r}0.059 \\
1.113 \\
2.727 \\
14.270\end{array}$ & $\begin{array}{r}0.108 \\
1.044 \\
2.300 \\
10.594\end{array}$ & $\begin{array}{l}0.136 \\
1.187 \\
1.741 \\
8.670\end{array}$ & $\begin{array}{l}0.013 \\
0.982 \\
0.199 \\
1.918\end{array}$ & $\begin{array}{l}0.040 \\
0.773 \\
0.126 \\
0.127\end{array}$ & $\begin{array}{r}0.043 \\
0.906 \\
-0.368 \\
0.730\end{array}$ \\
\hline \multicolumn{12}{|c|}{ 2nd Quintile, 1962 to 1996} \\
\hline $\begin{array}{l}\text { Mean } \\
\text { S.D. } \\
\text { Skew } \\
\text { Kurt }\end{array}$ & $\begin{array}{r}-0.000 \\
1.000 \\
0.844 \\
16.738\end{array}$ & $\begin{array}{r}-0.064 \\
0.848 \\
0.406 \\
2.127\end{array}$ & $\begin{array}{r}0.076 \\
0.991 \\
1.892 \\
11.561\end{array}$ & $\begin{array}{r}-0.109 \\
1.106 \\
-0.122 \\
2.496\end{array}$ & $\begin{array}{r}-0.093 \\
1.026 \\
0.635 \\
3.458\end{array}$ & $\begin{array}{r}-0.085 \\
0.805 \\
0.036 \\
0.689\end{array}$ & $\begin{array}{r}-0.038 \\
0.997 \\
0.455 \\
1.332\end{array}$ & $\begin{array}{r}-0.066 \\
0.898 \\
-0.579 \\
2.699\end{array}$ & $\begin{array}{r}-0.015 \\
0.897 \\
0.416 \\
3.871\end{array}$ & $\begin{array}{l}0.039 \\
1.119 \\
1.196 \\
3.910\end{array}$ & $\begin{array}{r}-0.034 \\
0.821 \\
0.190 \\
0.777\end{array}$ \\
\hline \multicolumn{12}{|c|}{ 3rd Quintile, 1962 to 1996} \\
\hline $\begin{array}{l}\text { Mean } \\
\text { S.D. } \\
\text { Skew } \\
\text { Kurt }\end{array}$ & $\begin{array}{r}-0.000 \\
1.000 \\
0.698 \\
12.161\end{array}$ & $\begin{array}{l}0.033 \\
0.933 \\
0.223 \\
1.520\end{array}$ & $\begin{array}{l}0.028 \\
0.906 \\
0.529 \\
1.526\end{array}$ & $\begin{array}{l}0.078 \\
0.931 \\
0.656 \\
1.003\end{array}$ & $\begin{array}{l}0.210 \\
0.971 \\
0.326 \\
0.430\end{array}$ & $\begin{array}{r}-0.030 \\
0.825 \\
0.539 \\
1.673\end{array}$ & $\begin{array}{l}0.068 \\
1.002 \\
0.442 \\
1.038\end{array}$ & $\begin{array}{l}0.117 \\
0.992 \\
0.885 \\
2.908\end{array}$ & $\begin{array}{l}0.210 \\
0.970 \\
0.820 \\
4.915\end{array}$ & $\begin{array}{r}-0.109 \\
0.997 \\
-0.163 \\
5.266\end{array}$ & $\begin{array}{r}-0.075 \\
0.973 \\
0.123 \\
2.573\end{array}$ \\
\hline \multicolumn{12}{|c|}{ 4th Quintile, 1962 to 1996} \\
\hline $\begin{array}{l}\text { Mean } \\
\text { S.D. } \\
\text { Skew } \\
\text { Kurt }\end{array}$ & $\begin{array}{r}0.000 \\
1.000 \\
0.655 \\
11.043\end{array}$ & $\begin{array}{r}-0.079 \\
0.911 \\
-0.456 \\
2.525\end{array}$ & $\begin{array}{r}0.037 \\
0.957 \\
2.671 \\
19.593\end{array}$ & $\begin{array}{r}-0.006 \\
0.992 \\
-0.174 \\
2.163\end{array}$ & $\begin{array}{r}-0.044 \\
0.975 \\
0.385 \\
1.601\end{array}$ & $\begin{array}{r}-0.080 \\
1.076 \\
0.554 \\
7.723\end{array}$ & $\begin{array}{l}0.007 \\
0.824 \\
0.717 \\
3.930\end{array}$ & $\begin{array}{l}0.084 \\
0.890 \\
0.290 \\
1.555\end{array}$ & $\begin{array}{l}0.044 \\
0.851 \\
1.034 \\
2.982\end{array}$ & $\begin{array}{l}0.038 \\
0.857 \\
0.154 \\
2.807\end{array}$ & $\begin{array}{r}-0.048 \\
0.819 \\
-0.149 \\
2.139\end{array}$ \\
\hline \multicolumn{12}{|c|}{ Largest Quintile, 1962 to 1996} \\
\hline $\begin{array}{l}\text { Mean } \\
\text { S.D. } \\
\text { Skew } \\
\text { Kurt }\end{array}$ & $\begin{array}{l}0.000 \\
1.000 \\
0.100 \\
7.976\end{array}$ & $\begin{array}{r}0.026 \\
0.952 \\
-0.266 \\
5.807\end{array}$ & $\begin{array}{r}0.058 \\
1.002 \\
-0.144 \\
4.367\end{array}$ & $\begin{array}{r}-0.070 \\
0.895 \\
1.699 \\
8.371\end{array}$ & $\begin{array}{l}0.031 \\
1.060 \\
1.225 \\
5.778\end{array}$ & $\begin{array}{l}0.052 \\
1.076 \\
0.409 \\
1.970\end{array}$ & $\begin{array}{r}-0.013 \\
0.871 \\
0.025 \\
2.696\end{array}$ & $\begin{array}{l}0.001 \\
0.794 \\
0.105 \\
1.336\end{array}$ & $\begin{array}{r}-0.024 \\
0.958 \\
1.300 \\
7.503\end{array}$ & $\begin{array}{l}0.032 \\
0.844 \\
0.315 \\
2.091\end{array}$ & $\begin{array}{r}-0.018 \\
0.877 \\
-0.363 \\
2.241\end{array}$ \\
\hline
\end{tabular}


Table IV (continued)

\begin{tabular}{|c|c|c|c|c|c|c|c|c|c|c|c|}
\hline Moment & Raw & HS & JHS & BTOP & BBOT & TTOP & ТВOT & RTOP & RBOT & DTOP & DBOT \\
\hline \multicolumn{12}{|c|}{ All Stocks, 1962 to 1966} \\
\hline Mean & -0.000 & 0.116 & 0.041 & 0.099 & 0.090 & 0.028 & -0.066 & 0.100 & 0.010 & 0.096 & 0.027 \\
\hline S.D. & 1.000 & 0.912 & 0.949 & 0.989 & 1.039 & 1.015 & 0.839 & 0.925 & 0.873 & 1.039 & 0.840 \\
\hline Skew & 0.575 & 0.711 & 1.794 & 0.252 & 1.258 & 1.601 & 0.247 & 2.016 & 1.021 & 0.533 & -0.351 \\
\hline Kurt & 6.555 & 1.538 & 9.115 & 2.560 & 6.445 & 7.974 & 1.324 & 13.653 & 5.603 & 6.277 & 2.243 \\
\hline \multicolumn{12}{|c|}{ All Stocks, 1967 to 1971} \\
\hline Mean & -0.000 & -0.127 & 0.114 & 0.121 & 0.016 & 0.045 & 0.077 & 0.154 & 0.136 & -0.000 & 0.006 \\
\hline S.D. & 1.000 & 0.864 & 0.805 & 0.995 & 1.013 & 0.976 & 0.955 & 1.016 & 1.118 & 0.882 & 0.930 \\
\hline Skew & 0.734 & -0.097 & 1.080 & 0.574 & 0.843 & 1.607 & 0.545 & 0.810 & 1.925 & 0.465 & 0.431 \\
\hline Kurt & 5.194 & 1.060 & 2.509 & 0.380 & 2.928 & 10.129 & 1.908 & 1.712 & 5.815 & 1.585 & 2.476 \\
\hline \multicolumn{12}{|c|}{ All Stocks, 1972 to 1976} \\
\hline Mean & 0.000 & 0.014 & 0.089 & -0.403 & -0.034 & -0.132 & -0.422 & -0.076 & 0.108 & -0.004 & -0.163 \\
\hline S.D. & 1.000 & 0.575 & 0.908 & 0.569 & 0.803 & 0.618 & 0.830 & 0.886 & 0.910 & 0.924 & 0.564 \\
\hline Skew & 0.466 & -0.281 & 0.973 & -1.176 & 0.046 & -0.064 & -1.503 & -2.728 & 2.047 & -0.551 & -0.791 \\
\hline Kurt & 17.228 & 2.194 & 1.828 & 0.077 & 0.587 & -0.444 & 2.137 & 13.320 & 9.510 & 1.434 & 2.010 \\
\hline \multicolumn{12}{|c|}{ All Stocks, 1977 to 1981} \\
\hline Mean & -0.000 & 0.025 & -0.212 & -0.112 & -0.056 & -0.110 & 0.086 & 0.055 & 0.177 & 0.081 . & 0.040 \\
\hline S.D. & 1.000 & 0.769 & 1.025 & 1.091 & 0.838 & 0.683 & 0.834 & 1.036 & 1.047 & 0.986 & 0.880 \\
\hline Skew & 1.092 & 0.230 & -1.516 & -0.731 & 0.368 & 0.430 & 0.249 & 2.391 & 2.571 & 1.520 & -0.291 \\
\hline Kurt & 20.043 & 1.618 & 4.397 & 3.766 & 0.460 & 0.962 & 4.722 & 9.137 & 10.961 & 7.127 & 3.682 \\
\hline \multicolumn{12}{|c|}{ All Stocks, 1982 to 1986} \\
\hline Mean & 0.000 & -0.147 & 0.204 & -0.137 & -0.001 & -0.053 & -0.022 & -0.028 & 0.116 & -0.224 & -0.052 \\
\hline S.D. & 1.000 & 1.073 & 1.442 & 0.804 & 1.040 & 0.982 & 1.158 & 0.910 & 0.830 & 0.868 & 1.082 \\
\hline Skew & 1.267 & -1.400 & 2.192 & 0.001 & 0.048 & 1.370 & 1.690 & -0.120 & 0.048 & 0.001 & -0.091 \\
\hline Kurt & 21.789 & 4.899 & 10.530 & 0.863 & 0.732 & 8.460 & 7.086 & 0.780 & 0.444 & 1.174 & 0.818 \\
\hline \multicolumn{12}{|c|}{ All Stocks, 1987 to 1991} \\
\hline Mean & 0.000 & 0.012 & 0.120 & -0.080 & -0.031 & -0.052 & 0.038 & 0.098 & 0.049 & -0.048 & -0.122 \\
\hline S.D. & 1.000 & 0.907 & 1.136 & 0.925 & 0.826 & 1.007 & 0.878 & 0.936 & 1.000 & 0.772 & 0.860 \\
\hline Skew & 0.104 & -0.326 & 0.976 & -0.342 & 0.234 & -0.248 & 1.002 & 0.233 & 0.023 & -0.105 & -0.375 \\
\hline Kurt & 12.688 & 3.922 & .5 .183 & 1.839 & 0.734 & 2.796 & 2.768 & 1.038 & 2.350 & 0.313 & 2.598 \\
\hline \multicolumn{12}{|c|}{ All Stocks, 1992 to 1996} \\
\hline Mean & 0.000 & -0.119 & -0.058 & -0.033 & -0.013 & -0.078 & 0.086 & -0.006 & -0.011 & 0.003 & -0.105 \\
\hline S.D. & 1.000 & 0.926 & 0.854 & 0.964 & 1.106 & 1.093 & 0.901 & 0.973 & 0.879 & 0.932 & 0.875 \\
\hline Skew & -0.036 & 0.079 & -0.015 & 1.399 & 0.158 & -0.127 & 0.150 & 0.283 & 0.236 & 0.039 & -0.097 \\
\hline Kurt & 5.377 & 2.818 & -0.059 & 7.584 & 0.626 & 2.019 & 1.040 & 1.266 & 1.445 & 1.583 & 0.205 \\
\hline
\end{tabular}




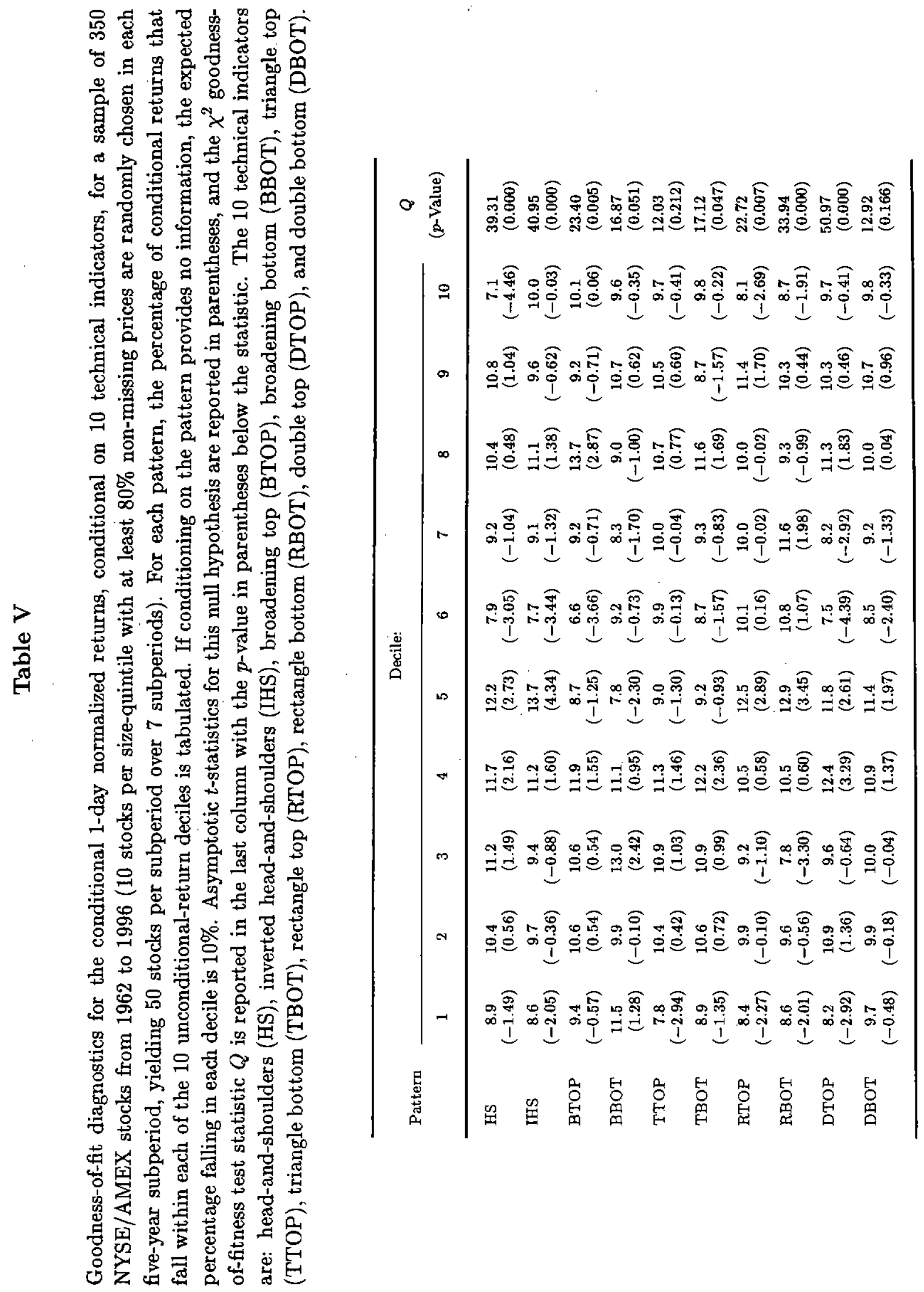




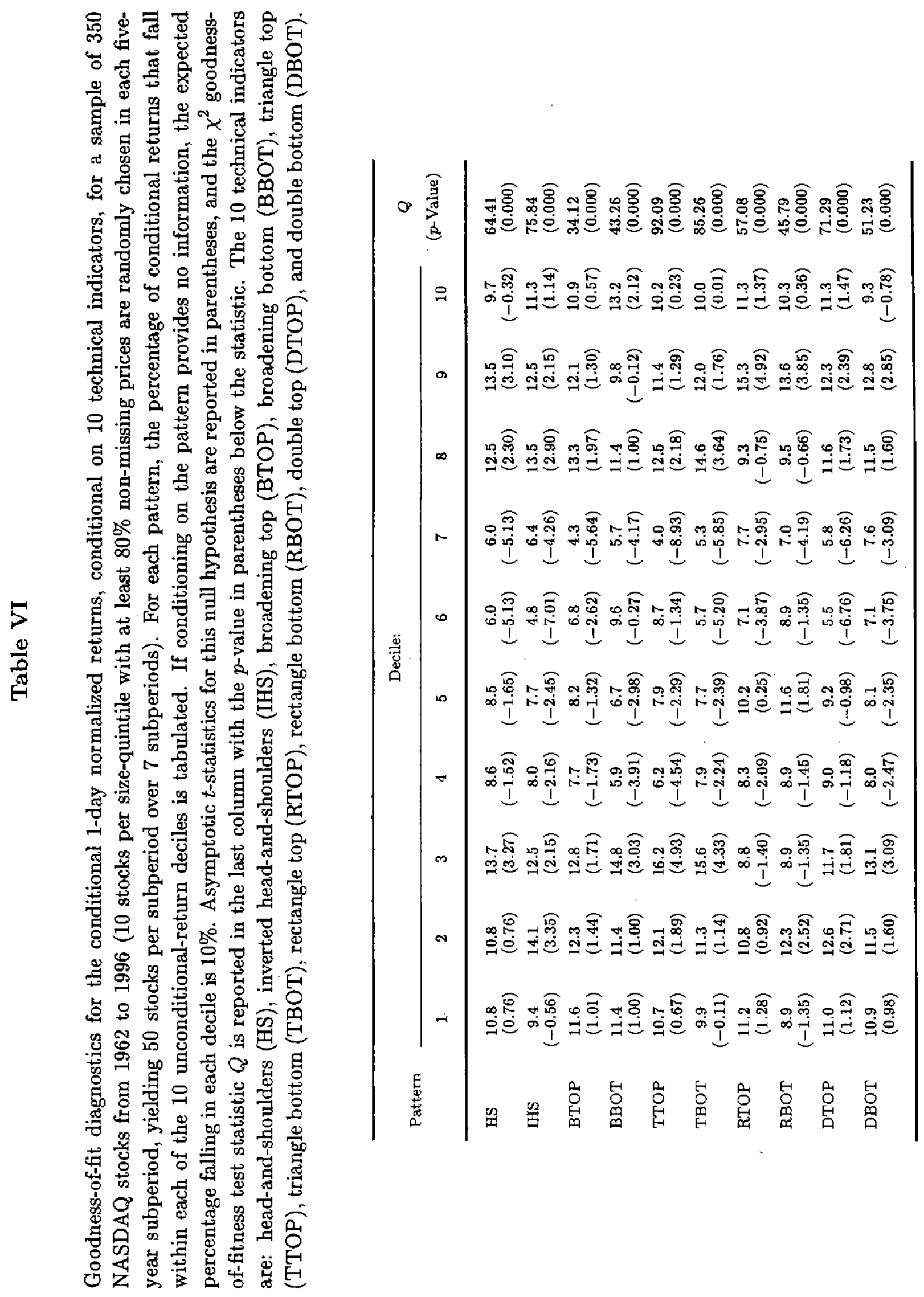




\section{Table VII}

Kolmogorov-Smirnov test of the equality of conditional and unconditional 1-day return distributions for NYSE/AMEX stocks from 1962 to 1996, in 5-year subperiods, and in size quintiles. Conditional returns are defined as the daily return three days following the conclusion of an occurrence of one of 10 technical indicators: head-and-shoulders (HS), inverted head-and-shoulders (IHS), broadening top (BTOP), broadening bottom (BBOT), triangle top (TTOP), triangle bottom (TBOT), rectangle top (RTOP), rectangle bottom (RBOT), double top (DTOP), and double bottom (DBOT). All returns have been normalized by subtraction of their means and division by their standard deviations. $p$-values are with respect to the asymptotic distribution of the Kolmogorov-Smirnov test statistic. The symbols ' $\tau(\searrow$ ') and ' $\tau(\nearrow)$ ' indicate that the conditional distribution is also conditioned on decreasing and increasing volume trend, respectively.

\begin{tabular}{lllllllllll}
\hline Statiatic & HS & IHS & BTOP & BBOT & TTOP & TBOT & RTOP & RBOT & DTOP & DBOT \\
\hline & & & \multicolumn{7}{c}{ All Stocks, 1962 to 1996} \\
$\gamma$ & $\mathbf{1 . 8 9}$ & 1.22 & $\mathbf{1 . 1 5}$ & $\mathbf{1 . 7 6}$ & $\mathbf{0 . 9 0}$ & $\mathbf{1 . 0 9}$ & $\mathbf{1 . 8 4}$ & $\mathbf{2 . 4 5}$ & 1.51 & $\mathbf{1 . 0 6}$ \\
$\boldsymbol{p}$-value & $\mathbf{0 . 0 0 2}$ & $\mathbf{0 . 1 0 4}$ & $\mathbf{0 . 1 3 9}$ & $\mathbf{0 . 0 0 4}$ & $\mathbf{0 . 3 9 3}$ & $\mathbf{0 . 1 8 5}$ & $\mathbf{0 . 0 0 2}$ & $\mathbf{0 . 0 0 0}$ & $\mathbf{0 . 0 2 1}$ & $\mathbf{0 . 2 1 5}$ \\
$\boldsymbol{\gamma} \boldsymbol{\tau}(\boldsymbol{y})$ & 1.49 & $\mathbf{0 . 9 5}$ & $\mathbf{0 . 4 4}$ & $\mathbf{0 . 6 2}$ & $\mathbf{0 . 7 3}$ & $\mathbf{1 . 3 3}$ & $\mathbf{1 . 3 7}$ & $\mathbf{1 . 7 7}$ & $\mathbf{0 . 9 6}$ & $\mathbf{0 . 7 8}$ \\
$\boldsymbol{p}$-value & $\mathbf{0 . 0 2 4}$ & $\mathbf{0 . 3 2 7}$ & $\mathbf{0 . 9 8 9}$ & $\mathbf{0 . 8 3 9}$ & $\mathbf{0 . 6 5 7}$ & $\mathbf{0 . 0 5 9}$ & $\mathbf{0 . 0 4 7}$ & $\mathbf{0 . 0 0 4}$ & $\mathbf{0 . 3 1 9}$ & $\mathbf{0 . 5 7 9}$ \\
$\boldsymbol{\gamma} \boldsymbol{\tau}(\boldsymbol{\gamma})$ & $\mathbf{0 . 7 2}$ & 1.05 & $\mathbf{1 . 3 3}$ & $\mathbf{1 . 5 9}$ & $\mathbf{0 . 9 2}$ & $\mathbf{1 . 2 9}$ & $\mathbf{1 . 1 3}$ & 1.24 & $\mathbf{0 . 7 4}$ & $\mathbf{0 . 8 4}$ \\
$\boldsymbol{p}$-value & $\mathbf{0 . 6 7 1}$ & $\mathbf{0 . 2 2 0}$ & $\mathbf{0 . 0 5 9}$ & $\mathbf{0 . 0 1 3}$ & $\mathbf{0 . 3 6 8}$ & $\mathbf{0 . 0 7 3}$ & $\mathbf{0 . 1 5 6}$ & $\mathbf{0 . 0 9 0}$ & $\mathbf{0 . 6 3 8}$ & 0.481 \\
$\boldsymbol{\gamma}$ Diff. & $\mathbf{0 . 8 8}$ & $\mathbf{0 . 5 4}$ & $\mathbf{0 . 5 9}$ & $\mathbf{0 . 9 4}$ & $\mathbf{0 . 7 5}$ & 1.37 & 0.79 & $\mathbf{1 . 2 0}$ & $\mathbf{0 . 8 2}$ & $\mathbf{0 . 7 1}$ \\
$\boldsymbol{p}$-value & $\mathbf{0 . 4 1 8}$ & $\mathbf{0 . 9 3 5}$ & $\mathbf{0 . 8 7 9}$ & $\mathbf{0 . 3 4 2}$ & $\mathbf{0 . 6 2 8}$ & $\mathbf{0 . 0 4 6}$ & $\mathbf{0 . 5 5 7}$ & $\mathbf{0 . 1 1 1}$ & $\mathbf{0 . 5 1 2}$ & $\mathbf{0 . 6 9 8}$ \\
\hline
\end{tabular}


Table VII (continued)

\begin{tabular}{|c|c|c|c|c|c|c|c|c|c|c|}
\hline Statistic & HS & IHS & BTOP & BBOT & TTOP & TBOT & RTOP & RBOT & DTOP & $\mathrm{DBOT}$ \\
\hline \multicolumn{11}{|c|}{ Smallest Quintile, 1962 to 1996} \\
\hline $\begin{array}{l}\gamma \\
p \text {-value }\end{array}$ & $\begin{array}{l}0.59 \\
0.872\end{array}$ & $\begin{array}{l}1.19 \\
0.116\end{array}$ & $\begin{array}{l}0.72 \\
0.679\end{array}$ & $\begin{array}{l}1.20 \\
0.114\end{array}$ & $\begin{array}{l}0.98 \\
0.290\end{array}$ & $\begin{array}{l}1.43 \\
0.033\end{array}$ & $\begin{array}{l}1.09 \\
0.188\end{array}$ & $\begin{array}{l}1.19 \\
0.120\end{array}$ & $\begin{array}{l}0.84 \\
0.485\end{array}$ & $\begin{array}{l}0.78 \\
0.583\end{array}$ \\
\hline $\begin{array}{l}\gamma \tau(x) \\
p \text {-value }\end{array}$ & $\begin{array}{l}0.67 \\
0.765\end{array}$ & $\begin{array}{l}0.80 \\
0.540\end{array}$ & $\begin{array}{l}1.16 \\
0.136\end{array}$ & $\begin{array}{l}0.69 \\
0.723\end{array}$ & $\begin{array}{l}1.00 \\
0.271\end{array}$ & $\begin{array}{l}1.46 \\
0.029\end{array}$ & $\begin{array}{l}1.31 \\
0.065\end{array}$ & $\begin{array}{l}0.94 \\
0.339\end{array}$ & $\begin{array}{l}1.12 \\
0.165\end{array}$ & $\begin{array}{l}0.73 \\
0.663\end{array}$ \\
\hline $\begin{array}{l}\gamma \tau(\lambda) \\
p \text {-value }\end{array}$ & $\begin{array}{l}0.43 \\
0.994\end{array}$ & $\begin{array}{l}0.95 \\
0.325\end{array}$ & $\begin{array}{l}0.67 \\
0.756\end{array}$ & $\begin{array}{l}1.03 \\
0.236\end{array}$ & $\begin{array}{l}0.47 \\
0.981\end{array}$ & $\begin{array}{l}0.88 \\
0.423\end{array}$ & $\begin{array}{l}0.51 \\
0.959\end{array}$ & $\begin{array}{l}0.93 \\
0.356\end{array}$ & $\begin{array}{l}0.94 \\
0.342\end{array}$ & $\begin{array}{l}0.58 \\
0.892\end{array}$ \\
\hline $\begin{array}{l}\gamma \text { Diff. } \\
p \text {-value }\end{array}$ & $\begin{array}{l}0.52 \\
0.951\end{array}$ & $\begin{array}{l}0.48 \\
0.974\end{array}$ & $\begin{array}{l}1.14 \\
0.151\end{array}$ & $\begin{array}{l}0.68 \\
0.741\end{array}$ & $\begin{array}{l}0.48 \\
0.976\end{array}$ & $\begin{array}{l}0.98 \\
0.291\end{array}$ & $\begin{array}{l}0.98 \\
0.294\end{array}$ & $\begin{array}{l}0.79 \\
0.552\end{array}$ & $\begin{array}{l}1.16 \\
0.133\end{array}$ & $\begin{array}{l}0.62 \\
0.840\end{array}$ \\
\hline \multicolumn{11}{|c|}{ 2nd Quintile, 1962 to 1996} \\
\hline $\begin{array}{l}\gamma \\
p \text {-value }\end{array}$ & $\begin{array}{l}1.82 \\
0.003\end{array}$ & $\begin{array}{l}1.63 \\
0.010\end{array}$ & $\begin{array}{l}0.93 \\
0.353\end{array}$ & $\begin{array}{l}0.92 \\
0.365\end{array}$ & $\begin{array}{l}0.82 \\
0.505\end{array}$ & $\begin{array}{l}0.84 \\
0.485\end{array}$ & $\begin{array}{l}0.88 \\
0.417\end{array}$ & $\begin{array}{l}1.29 \\
0.073\end{array}$ & $\begin{array}{l}1.46 \\
0.029\end{array}$ & $\begin{array}{l}0.84 \\
0.478\end{array}$ \\
\hline $\begin{array}{l}\gamma \tau(\nu) \\
p \text {-value }\end{array}$ & $\begin{array}{l}1.62 \\
0.010\end{array}$ & $\begin{array}{l}1.03 \\
0.242\end{array}$ & $\begin{array}{l}0.88 \\
0.427\end{array}$ & $\begin{array}{l}0.42 \\
0.994\end{array}$ & $\begin{array}{l}0.91 \\
0.378\end{array}$ & $\begin{array}{l}0.90 \\
0.394\end{array}$ & $\begin{array}{l}0.71 \\
0.703\end{array}$ & $\begin{array}{l}0.86 \\
0.443\end{array}$ & $\begin{array}{l}1.50 \\
0.022\end{array}$ & $\begin{array}{l}0.97 \\
0.298\end{array}$ \\
\hline $\begin{array}{l}\gamma \tau(\mu) \\
p \text {-value }\end{array}$ & $\begin{array}{l}1.06 \\
0.213\end{array}$ & $\begin{array}{l}1.63 \\
0.010\end{array}$ & $\begin{array}{l}0.96 \\
0.317\end{array}$ & $\begin{array}{l}0.83 \\
0.497\end{array}$ & $\begin{array}{l}0.89 \\
0.407\end{array}$ & $\begin{array}{l}0.98 \\
0.289\end{array}$ & $\begin{array}{l}1.19 \\
0.119\end{array}$ & $\begin{array}{l}1.15 \\
0.141\end{array}$ & $\begin{array}{l}0.96 \\
0.317\end{array}$ & $\begin{array}{l}0.99 \\
0.286\end{array}$ \\
\hline $\begin{array}{l}\gamma \text { Diff. } \\
p \text {-value }\end{array}$ & $\begin{array}{l}0.78 \\
0.576\end{array}$ & $\begin{array}{l}0.94 \\
0.334\end{array}$ & $\begin{array}{l}1.04 \\
0.228\end{array}$ & $\begin{array}{l}0.71 \\
0.687\end{array}$ & $\begin{array}{l}1.22 \\
0.102\end{array}$ & $\begin{array}{l}0.92 \\
0.361\end{array}$ & $\begin{array}{l}0.99 \\
0.276\end{array}$ & $\begin{array}{l}0.79 \\
0.564\end{array}$ & $\begin{array}{l}1.18 \\
0.126\end{array}$ & $\begin{array}{l}0.68 \\
0.745\end{array}$ \\
\hline \multicolumn{11}{|c|}{ 3rd Quintile, 1962 to 1996} \\
\hline $\begin{array}{l}\gamma \\
p \text {-value }\end{array}$ & $\begin{array}{l}0.83 \\
0.502\end{array}$ & $\begin{array}{l}1.56 \\
0.016\end{array}$ & $\begin{array}{l}1.00 \\
0.266\end{array}$ & $\begin{array}{l}1.28 \\
0.074\end{array}$ & $\begin{array}{l}0.57 \\
0.903\end{array}$ & $\begin{array}{l}1.03 \\
0.243\end{array}$ & $\begin{array}{l}1.96 \\
0.001\end{array}$ & $\begin{array}{l}1.50 \\
0.023\end{array}$ & $\begin{array}{l}1.55 \\
0.016\end{array}$ & $\begin{array}{l}1.14 \\
0.150\end{array}$ \\
\hline $\begin{array}{l}\gamma \tau(x) \\
p \text {-value }\end{array}$ & $\begin{array}{l}0.95 \\
0.326\end{array}$ & $\begin{array}{l}0.94 \\
0.346\end{array}$ & $\begin{array}{l}0.66 \\
0.775\end{array}$ & $\begin{array}{l}0.76 \\
0.613\end{array}$ & $\begin{array}{l}0.61 \\
0.854\end{array}$ & $\begin{array}{l}0.82 \\
0.520\end{array}$ & $\begin{array}{l}1.45 \\
0.031\end{array}$ & $\begin{array}{l}1.61 \\
0.012\end{array}$ & $\begin{array}{l}1.17 \\
0.131\end{array}$ & $\begin{array}{l}1.01 \\
0.258\end{array}$ \\
\hline $\begin{array}{l}\gamma \tau(\mu) \\
p \text {-value }\end{array}$ & $\begin{array}{l}1.05 \\
0.223\end{array}$ & $\begin{array}{l}1.43 \\
0.033\end{array}$ & $\begin{array}{l}0.93 \\
0.350\end{array}$ & $\begin{array}{l}1.14 \\
0.147\end{array}$ & $\begin{array}{l}0.63 \\
0.826\end{array}$ & $\begin{array}{l}0.80 \\
0.544\end{array}$ & $\begin{array}{l}0.93 \\
0.354\end{array}$ & $\begin{array}{l}0.78 \\
0.578\end{array}$ & $\begin{array}{l}0.59 \\
0.878\end{array}$ & $\begin{array}{l}0.86 \\
0.450\end{array}$ \\
\hline $\begin{array}{l}\gamma \text { Diff. } \\
p \text {-value }\end{array}$ & $\begin{array}{l}1.02 \\
0.246\end{array}$ & $\begin{array}{l}1.14 \\
0.148\end{array}$ & $\begin{array}{l}0.45 \\
0.986\end{array}$ & $\begin{array}{l}0.48 \\
0.974\end{array}$ & $\begin{array}{l}0.50 \\
0.964\end{array}$ & $\begin{array}{l}0.89 \\
0.413\end{array}$ & $\begin{array}{l}0.66 \\
0.774\end{array}$ & $\begin{array}{l}0.91 \\
0.383\end{array}$ & $\begin{array}{l}0.72 \\
0.670\end{array}$ & $\begin{array}{l}1.15 \\
0.143\end{array}$ \\
\hline \multicolumn{11}{|c|}{ 4th Quintile, 1962 to 1996} \\
\hline $\begin{array}{l}\gamma \\
p \text {-value }\end{array}$ & $\begin{array}{l}0.72 \\
0.683\end{array}$ & $\begin{array}{l}0.61 \\
0.852\end{array}$ & $\begin{array}{l}1.29 \\
0.071\end{array}$ & $\begin{array}{l}0.84 \\
0.479\end{array}$ & $\begin{array}{l}0.61 \\
0.855\end{array}$ & $\begin{array}{l}0.84 \\
0.480\end{array}$ & $\begin{array}{l}1.37 \\
0.048\end{array}$ & $\begin{array}{l}1.37 \\
0.047\end{array}$ & $\begin{array}{l}0.72 \\
0.682\end{array}$ & $\begin{array}{l}0.53 \\
0.943\end{array}$ \\
\hline $\begin{array}{l}\gamma \tau(\searrow) \\
p \text {-value }\end{array}$ & $\begin{array}{l}1.01 \\
0.255\end{array}$ & $\begin{array}{l}0.95 \\
0.330\end{array}$ & $\begin{array}{l}0.83 \\
0.504\end{array}$ & $\begin{array}{l}0.96 \\
0.311\end{array}$ & $\begin{array}{l}0.78 \\
0.585\end{array}$ & $\begin{array}{l}0.84 \\
0.487\end{array}$ & $\begin{array}{l}1.34 \\
0.056\end{array}$ & $\begin{array}{l}0.72 \\
0.680\end{array}$ & $\begin{array}{l}0.62 \\
0.841\end{array}$ & $\begin{array}{l}1.01 \\
0.258\end{array}$ \\
\hline $\begin{array}{l}\gamma \tau(\lambda) \\
p \text {-value }\end{array}$ & $\begin{array}{l}0.93 \\
0.349\end{array}$ & $\begin{array}{l}0.66 \\
0.772\end{array}$ & $\begin{array}{l}1.29 \\
0.072\end{array}$ & $\begin{array}{l}0.96 \\
0.316\end{array}$ & $\begin{array}{l}1.16 \\
0.137\end{array}$ & $\begin{array}{l}0.69 \\
0.731\end{array}$ & $\begin{array}{l}0.64 \\
0.810\end{array}$ & $\begin{array}{l}1.16 \\
0.136\end{array}$ & $\begin{array}{l}0.69 \\
0.720\end{array}$ & $\begin{array}{l}0.85 \\
0.468\end{array}$ \\
\hline $\begin{array}{l}\gamma \text { Diff. } \\
p \text {-value }\end{array}$ & $\begin{array}{l}1.10 \\
0.175\end{array}$ & $\begin{array}{l}0.97 \\
0.301\end{array}$ & $\begin{array}{l}0.64 \\
0.804\end{array}$ & $\begin{array}{l}1.16 \\
0.138\end{array}$ & $\begin{array}{l}1.31 \\
0.065\end{array}$ & $\begin{array}{l}0.78 \\
0.571\end{array}$ & $\begin{array}{l}0.64 \\
0.806\end{array}$ & $\begin{array}{l}0.92 \\
0.363\end{array}$ & $\begin{array}{l}0.66 \\
0.780\end{array}$ & $\begin{array}{l}1.10 \\
0.176\end{array}$ \\
\hline \multicolumn{11}{|c|}{ Largest Quintile, 1962 to 1996} \\
\hline$\underset{p \text {-value }}{\gamma}$ & $\begin{array}{l}1.25 \\
0.088\end{array}$ & $\begin{array}{l}1.16 \\
0.136\end{array}$ & $\begin{array}{l}0.98 \\
0.287\end{array}$ & $\begin{array}{l}0.48 \\
0.977\end{array}$ & $\begin{array}{l}0.50 \\
0.964\end{array}$ & $\begin{array}{l}0.80 \\
0.544\end{array}$ & $\begin{array}{l}0.94 \\
0.346\end{array}$ & $\begin{array}{l}1.76 \\
0.004\end{array}$ & $\begin{array}{l}0.90 \\
0.395\end{array}$ & $\begin{array}{l}1.28 \\
0.077\end{array}$ \\
\hline $\begin{array}{l}\gamma \tau(x) \\
p \text {-value }\end{array}$ & $\begin{array}{l}1.12 \\
0.164\end{array}$ & $\begin{array}{l}0.90 \\
0.386\end{array}$ & $\begin{array}{l}0.57 \\
0.906\end{array}$ & $\begin{array}{l}0.78 \\
0.580\end{array}$ & $\begin{array}{l}0.64 \\
0.806\end{array}$ & $\begin{array}{l}1.17 \\
0.127\end{array}$ & $\begin{array}{l}0.91 \\
0.379\end{array}$ & $\begin{array}{l}0.87 \\
0.442\end{array}$ & $\begin{array}{l}0.64 \\
0.802\end{array}$ & $\begin{array}{l}1.20 \\
0.114\end{array}$ \\
\hline $\begin{array}{l}\gamma \tau(\mu) \\
p \text {-value }\end{array}$ & $\begin{array}{l}0.81 \\
0.522\end{array}$ & $\begin{array}{l}0.93 \\
0.350\end{array}$ & $\begin{array}{l}0.83 \\
0.495\end{array}$ & $\begin{array}{l}0.61 \\
0.854\end{array}$ & $\begin{array}{l}0.69 \\
0.729\end{array}$ & $\begin{array}{l}0.81 \\
0.532\end{array}$ & $\begin{array}{l}0.73 \\
0.661\end{array}$ & $\begin{array}{l}0.87 \\
0.432\end{array}$ & $\begin{array}{l}0.46 \\
0.982\end{array}$ & $\begin{array}{l}0.88 \\
0.418\end{array}$ \\
\hline $\begin{array}{l}\gamma \text { Diff. } \\
p \text {-value }\end{array}$ & $\begin{array}{l}0.71 \\
0.699\end{array}$ & $\begin{array}{l}0.54 \\
0.934\end{array}$ & $\begin{array}{l}0.59 \\
0.874\end{array}$ & $\begin{array}{l}0.64 \\
0.800\end{array}$ & $\begin{array}{l}0.76 \\
0.607\end{array}$ & $\begin{array}{l}1.21 \\
0.110\end{array}$ & $\begin{array}{l}0.85 \\
0.467\end{array}$ & $\begin{array}{l}1.11 \\
0.170\end{array}$ & $\begin{array}{l}0.54 \\
0.929\end{array}$ & $\begin{array}{l}0.79 \\
0.552\end{array}$ \\
\hline
\end{tabular}


Table VII (continued)

\begin{tabular}{|c|c|c|c|c|c|c|c|c|c|c|}
\hline Statistic & HS & IHS & BTOP & BBOT & TTOP & TBOT & RTOP & RBOT & DTOP & DBOT \\
\hline \multicolumn{11}{|c|}{ All Stocks, 1962 to 1966} \\
\hline$\underset{p \text {-value }}{\gamma}$ & $\begin{array}{l}1.29 \\
0.072\end{array}$ & $\begin{array}{l}1.67 \\
0.007\end{array}$ & $\begin{array}{l}1.07 \\
0.202\end{array}$ & $\begin{array}{l}0.72 \\
0.671\end{array}$ & $\begin{array}{l}0.75 \\
0.634\end{array}$ & $\begin{array}{l}1.32 \\
0.062\end{array}$ & $\begin{array}{l}1.20 \\
0.112\end{array}$ & $\begin{array}{l}1.53 \\
0.018\end{array}$ & $\begin{array}{l}2.04 \\
0.001\end{array}$ & $\begin{array}{l}1.73 \\
0.005\end{array}$ \\
\hline $\begin{array}{l}\gamma \tau(\nu) \\
p \text {-value }\end{array}$ & $\begin{array}{l}0.83 \\
0.499\end{array}$ & $\begin{array}{l}1.01 \\
0.260\end{array}$ & $\begin{array}{l}1.04 \\
0.232\end{array}$ & $\begin{array}{l}0.80 \\
0.539\end{array}$ & $\begin{array}{l}0.63 \\
0.826\end{array}$ & $\begin{array}{l}1.80 \\
0.003\end{array}$ & $\begin{array}{l}0.66 \\
0.771\end{array}$ & $\begin{array}{l}1.84 \\
0.002\end{array}$ & $\begin{array}{l}1.03 \\
0.244\end{array}$ & $\begin{array}{l}1.54 \\
0.017\end{array}$ \\
\hline $\begin{array}{l}\gamma \tau(\mu) \\
p \text {-value }\end{array}$ & $\begin{array}{l}1.13 \\
0.156\end{array}$ & $\begin{array}{l}1.13 \\
0.153\end{array}$ & $\begin{array}{l}0.84 \\
0.480\end{array}$ & $\begin{array}{l}0.84 \\
0.475\end{array}$ & $\begin{array}{l}0.58 \\
0.894\end{array}$ & $\begin{array}{l}1.40 \\
0.040\end{array}$ & $\begin{array}{l}1.12 \\
0.163\end{array}$ & $\begin{array}{l}0.83 \\
0.492\end{array}$ & $\begin{array}{l}1.09 \\
0.183\end{array}$ & $\begin{array}{l}1.16 \\
0.135\end{array}$ \\
\hline $\begin{array}{l}\gamma \text { Diff. } \\
p \text {-value }\end{array}$ & $\begin{array}{l}0.65 \\
0.799\end{array}$ & $\begin{array}{l}0.71 \\
0.691\end{array}$ & $\begin{array}{l}0.75 \\
0.629\end{array}$ & $\begin{array}{l}0.76 \\
0.615\end{array}$ & $\begin{array}{l}0.60 \\
0.863\end{array}$ & $\begin{array}{l}1.90 \\
0.001\end{array}$ & $\begin{array}{l}0.68 \\
0.741\end{array}$ & $\begin{array}{l}1.35 \\
0.052\end{array}$ & $\begin{array}{l}0.73 \\
0.657\end{array}$ & $\begin{array}{l}0.83 \\
0.503\end{array}$ \\
\hline \multicolumn{11}{|c|}{ All Stocks, 1967 to 1971} \\
\hline $\begin{array}{l}\gamma \\
p \text {-value }\end{array}$ & $\begin{array}{l}1.10 \\
0.177\end{array}$ & $\begin{array}{l}0.96 \\
0.317\end{array}$ & $\begin{array}{l}0.60 \\
0.867\end{array}$ & $\begin{array}{l}0.65 \\
0.797\end{array}$ & $\begin{array}{l}0.98 \\
0.292\end{array}$ & $\begin{array}{l}0.76 \\
0.606\end{array}$ & $\begin{array}{l}1.29 \\
0.071\end{array}$ & $\begin{array}{l}1.65 \\
0.009\end{array}$ & $\begin{array}{l}0.87 \\
0.436\end{array}$ & $\begin{array}{l}1.22 \\
0.101\end{array}$ \\
\hline $\begin{array}{l}\gamma \tau(\nu) \\
p \text {-value }\end{array}$ & $\begin{array}{l}1.02 \\
0.248\end{array}$ & $\begin{array}{l}0.80 \\
0.551\end{array}$ & $\begin{array}{l}0.53 \\
0.943\end{array}$ & $\begin{array}{l}0.85 \\
0.464\end{array}$ & $\begin{array}{l}0.97 \\
0.303\end{array}$ & $\begin{array}{l}0.77 \\
0.590\end{array}$ & $\begin{array}{l}0.71 \\
0.700\end{array}$ & $\begin{array}{l}1.42 \\
0.035\end{array}$ & $\begin{array}{l}0.97 \\
0.300\end{array}$ & $\begin{array}{l}1.06 \\
0.214\end{array}$ \\
\hline $\begin{array}{c}\gamma \tau(\gamma) \\
p \text {-value }\end{array}$ & $\begin{array}{l}1.08 \\
0.190\end{array}$ & $\begin{array}{l}0.86 \\
0.454\end{array}$ & $\begin{array}{l}0.68 \\
0.750\end{array}$ & $\begin{array}{l}0.91 \\
0.373\end{array}$ & $\begin{array}{l}1.11 \\
0.169\end{array}$ & $\begin{array}{l}0.82 \\
0.508\end{array}$ & $\begin{array}{l}0.79 \\
0.554\end{array}$ & $\begin{array}{l}0.73 \\
0.660\end{array}$ & $\begin{array}{l}0.71 \\
0.699\end{array}$ & $\begin{array}{l}0.96 \\
0.315\end{array}$ \\
\hline $\begin{array}{l}\gamma \text { Diff. } \\
p \text {-value }\end{array}$ & $\begin{array}{l}1.36 \\
0.049\end{array}$ & $\begin{array}{l}0.51 \\
0.956\end{array}$ & $\begin{array}{l}0.53 \\
0.942\end{array}$ & $\begin{array}{l}0.76 \\
0.616\end{array}$ & $\begin{array}{l}0.68 \\
0.751\end{array}$ & $\begin{array}{l}0.71 \\
0.699\end{array}$ & $\begin{array}{l}0.71 \\
0.701\end{array}$ & $\begin{array}{l}0.98 \\
0.290\end{array}$ & $\begin{array}{l}1.06 \\
0.210\end{array}$ & $\begin{array}{l}1.12 \\
0.163\end{array}$ \\
\hline \multicolumn{11}{|c|}{ All Stocks, 1972 to 1976} \\
\hline $\begin{array}{l}\gamma \\
p \text {-value }\end{array}$ & $\begin{array}{l}0.47 \\
0.980\end{array}$ & $\begin{array}{l}0.75 \\
0.620\end{array}$ & $\begin{array}{l}0.87 \\
0.441\end{array}$ & $\begin{array}{l}1.56 \\
0.015\end{array}$ & $\begin{array}{l}1.21 \\
0.106\end{array}$ & $\begin{array}{l}0.75 \\
0.627\end{array}$ & $\begin{array}{l}0.87 \\
0.441\end{array}$ & $\begin{array}{l}0.94 \\
0.341\end{array}$ & $\begin{array}{l}1.64 \\
0.009\end{array}$ & $\begin{array}{l}1.20 \\
0.113\end{array}$ \\
\hline $\begin{array}{l}\gamma \tau(\nu) \\
p \text {-value }\end{array}$ & $\begin{array}{l}0.80 \\
0.539\end{array}$ & $\begin{array}{l}0.40 \\
0.998\end{array}$ & $\begin{array}{l}0.50 \\
0.966\end{array}$ & $\begin{array}{l}1.24 \\
0.093\end{array}$ & $\begin{array}{l}1.21 \\
0.106\end{array}$ & $\begin{array}{l}0.65 \\
0.794\end{array}$ & $\begin{array}{l}1.26 \\
0.084\end{array}$ & $\begin{array}{l}0.63 \\
0.821\end{array}$ & $\begin{array}{l}0.70 \\
0.718\end{array}$ & $\begin{array}{l}1.39 \\
0.041\end{array}$ \\
\hline $\begin{array}{l}\gamma \tau(\mu) \\
p \text {-value }\end{array}$ & $\begin{array}{l}0.49 \\
0.970\end{array}$ & $\begin{array}{l}0.78 \\
0.577\end{array}$ & $\begin{array}{l}0.94 \\
0.340\end{array}$ & $\begin{array}{l}1.21 \\
0.108\end{array}$ & $\begin{array}{l}1.12 \\
0.159\end{array}$ & $\begin{array}{l}1.03 \\
0.244\end{array}$ & $\begin{array}{l}0.81 \\
0.521\end{array}$ & $\begin{array}{l}0.95 \\
0.331\end{array}$ & $\begin{array}{l}0.84 \\
0.485\end{array}$ & $\begin{array}{l}0.70 \\
0.719\end{array}$ \\
\hline $\begin{array}{l}\gamma \text { Diff. } \\
p \text {-value }\end{array}$ & $\begin{array}{l}0.55 \\
0.925\end{array}$ & $\begin{array}{l}0.56 \\
0.915\end{array}$ & $\begin{array}{l}0.51 \\
0.960\end{array}$ & $\begin{array}{l}0.95 \\
0.333\end{array}$ & $\begin{array}{l}0.81 \\
0.525\end{array}$ & $\begin{array}{l}1.11 \\
0.170\end{array}$ & $\begin{array}{l}1.15 \\
0.141\end{array}$ & $\begin{array}{l}0.62 \\
0.836\end{array}$ & $\begin{array}{l}0.67 \\
0.767\end{array}$ & $\begin{array}{l}1.31 \\
0.065\end{array}$ \\
\hline \multicolumn{11}{|c|}{ All Stocks, 1977 to 1981} \\
\hline $\begin{array}{l}\gamma \\
p \text {-value }\end{array}$ & $\begin{array}{l}1.16 \\
0.138\end{array}$ & $\begin{array}{l}0.73 \\
0.665\end{array}$ & $\begin{array}{l}0.76 \\
0.617\end{array}$ & $\begin{array}{l}1.16 \\
0.136\end{array}$ & $\begin{array}{l}0.82 \\
0.506\end{array}$ & $\begin{array}{l}1.14 \\
0.147\end{array}$ & $\begin{array}{l}1.01 \\
0.263\end{array}$ & $\begin{array}{l}0.87 \\
0.428\end{array}$ & $\begin{array}{l}0.86 \\
0.449\end{array}$ & $\begin{array}{l}1.79 \\
0.003\end{array}$ \\
\hline $\begin{array}{l}\gamma \tau(y) \\
p \text {-value }\end{array}$ & $\begin{array}{l}1.04 \\
0.228\end{array}$ & $\begin{array}{l}0.73 \\
0.654\end{array}$ & $\begin{array}{l}1.00 \\
0.274\end{array}$ & $\begin{array}{l}1.31 \\
0.065\end{array}$ & $\begin{array}{l}1.10 \\
0.176\end{array}$ & $\begin{array}{l}1.32 \\
0.062\end{array}$ & $\begin{array}{l}0.83 \\
0.494\end{array}$ & $\begin{array}{l}0.80 \\
0.550\end{array}$ & $\begin{array}{l}1.20 \\
0.113\end{array}$ & $\begin{array}{l}1.81 \\
0.003\end{array}$ \\
\hline $\begin{array}{l}\gamma \tau(\mu) \\
p \text {-value }\end{array}$ & $\begin{array}{l}0.75 \\
0.623\end{array}$ & $\begin{array}{l}0.84 \\
0.476\end{array}$ & $\begin{array}{l}0.88 \\
0.426\end{array}$ & $\begin{array}{l}0.65 \\
0.799\end{array}$ & $\begin{array}{l}0.67 \\
0.754\end{array}$ & $\begin{array}{l}0.76 \\
0.602\end{array}$ & $\begin{array}{l}1.51 \\
0.020 .\end{array}$ & $\begin{array}{l}1.41 \\
0.037\end{array}$ & $\begin{array}{l}0.86 \\
0.450\end{array}$ & $\begin{array}{l}0.99 \\
0.280\end{array}$ \\
\hline $\begin{array}{l}\gamma \text { Diff. } \\
p \text {-value }\end{array}$ & $\begin{array}{l}0.67 \\
0.767\end{array}$ & $\begin{array}{l}0.94 \\
0.335\end{array}$ & $\begin{array}{l}0.88 \\
0.423\end{array}$ & $\begin{array}{l}0.70 \\
0.708\end{array}$ & $\begin{array}{l}0.65 \\
0.785\end{array}$ & $\begin{array}{l}0.70 \\
0.716\end{array}$ & $\begin{array}{l}1.11 \\
0.172\end{array}$ & $\begin{array}{l}1.29 \\
0.073\end{array}$ & $\begin{array}{l}1.16 \\
0.137\end{array}$ & $\begin{array}{l}0.70 \\
0.713\end{array}$ \\
\hline
\end{tabular}


Table VII (continued)

\begin{tabular}{|c|c|c|c|c|c|c|c|c|c|c|}
\hline Statistic & HS & IHS & BTOP & BBOT & TTOP & TBOT & RTOP & RBOT & DTOP & DBOT \\
\hline \multicolumn{11}{|c|}{ All Stocks, 1982 to 1986} \\
\hline $\begin{array}{l}\gamma \\
p \text {-value }\end{array}$ & $\begin{array}{l}1.57 \\
0.015\end{array}$ & $\begin{array}{l}0.99 \\
0.276\end{array}$ & $\begin{array}{l}0.59 \\
0.883\end{array}$ & $\begin{array}{l}1.46 \\
0.029\end{array}$ & $\begin{array}{l}1.47 \\
0.027\end{array}$ & $\begin{array}{l}1.04 \\
0.232\end{array}$ & $\begin{array}{l}0.87 \\
0.431\end{array}$ & $\begin{array}{l}0.68 \\
0.742\end{array}$ & $\begin{array}{l}0.76 \\
0.617\end{array}$ & $\begin{array}{l}0.90 \\
0.387\end{array}$ \\
\hline $\begin{array}{l}y \tau(y) \\
p \text {-value }\end{array}$ & $\begin{array}{l}1.17 \\
0.129\end{array}$ & $\begin{array}{l}0.68 \\
0.741\end{array}$ & $\begin{array}{l}0.44 \\
0.991\end{array}$ & $\begin{array}{l}1.30 \\
0.070\end{array}$ & $\begin{array}{l}1.53 \\
0.018\end{array}$ & $\begin{array}{l}1.21 \\
0.106\end{array}$ & $\begin{array}{l}1.08 \\
0.190\end{array}$ & $\begin{array}{l}0.93 \\
0.356\end{array}$ & $\begin{array}{l}0.84 \\
0.478\end{array}$ & $\begin{array}{l}0.88 \\
0.421\end{array}$ \\
\hline $\begin{array}{l}y \tau(\lambda) \\
p \text {-value }\end{array}$ & $\begin{array}{l}0.81 \\
0.533\end{array}$ & $\begin{array}{l}1.03 \\
0.243\end{array}$ & $\begin{array}{l}0.74 \\
0.640\end{array}$ & $\begin{array}{l}0.62 \\
0.831\end{array}$ & $\begin{array}{l}0.83 \\
0.499\end{array}$ & $\begin{array}{l}1.23 \\
0.097\end{array}$ & $\begin{array}{l}0.77 \\
0.597\end{array}$ & $\begin{array}{l}0.79 \\
0.564\end{array}$ & $\begin{array}{l}0.63 \\
0.821\end{array}$ & $\begin{array}{l}0.81 \\
0.528\end{array}$ \\
\hline $\begin{array}{l}y \text { Diff. } \\
p \text {-value }\end{array}$ & $\begin{array}{l}0.51 \\
0.961\end{array}$ & $\begin{array}{l}0.79 \\
0.567\end{array}$ & $\begin{array}{l}0.70 \\
0.717\end{array}$ & $\begin{array}{l}0.81 \\
0.532\end{array}$ & $\begin{array}{l}0.74 \\
0.643\end{array}$ & $\begin{array}{l}1.21 \\
0.107\end{array}$ & $\begin{array}{l}0.73 \\
0.657\end{array}$ & $\begin{array}{l}0.75 \\
0.623\end{array}$ & $\begin{array}{l}0.93 \\
0.352\end{array}$ & $\begin{array}{l}0.74 \\
0.642\end{array}$ \\
\hline \multicolumn{11}{|c|}{ All Stocks, 1987 to 1991} \\
\hline $\begin{array}{l}\gamma \\
p \text {-value }\end{array}$ & $\begin{array}{l}1.36 \\
0.048\end{array}$ & $\begin{array}{l}1.53 \\
0.019\end{array}$ & $\begin{array}{l}1.05 \\
0.219\end{array}$ & $\begin{array}{l}0.67 \\
0.756\end{array}$ & $\begin{array}{l}0.75 \\
0.627\end{array}$ & $\begin{array}{l}0.86 \\
0.456\end{array}$ & $\begin{array}{l}0.60 \\
0.862\end{array}$ & $\begin{array}{l}1.09 \\
0.185\end{array}$ & $\begin{array}{l}1.20 \\
0.111\end{array}$ & $\begin{array}{l}0.67 \\
0.764\end{array}$ \\
\hline $\begin{array}{l}\gamma \tau(\nu) \\
p \text {-value }\end{array}$ & $\begin{array}{l}0.52 \\
0.953\end{array}$ & $\begin{array}{l}1.16 \\
0.135\end{array}$ & $\begin{array}{l}1.25 \\
0.087\end{array}$ & $\begin{array}{l}0.72 \\
0.673\end{array}$ & $\begin{array}{l}1.03 \\
0.235\end{array}$ & $\begin{array}{l}0.81 \\
0.522\end{array}$ & $\begin{array}{l}0.81 \\
0.527\end{array}$ & $\begin{array}{l}0.61 \\
0.848\end{array}$ & $\begin{array}{l}1.07 \\
0.201\end{array}$ & $\begin{array}{l}0.68 \\
0.751\end{array}$ \\
\hline $\begin{array}{l}\gamma \tau(\lambda) \\
p \text {-value }\end{array}$ & $\begin{array}{l}1.72 \\
0.006\end{array}$ & $\begin{array}{l}1.03 \\
0.241\end{array}$ & $\begin{array}{l}0.64 \\
0.813\end{array}$ & $\begin{array}{l}1.37 \\
0.046\end{array}$ & $\begin{array}{l}0.74 \\
0.639\end{array}$ & $\begin{array}{l}1.10 \\
0.181\end{array}$ & $\begin{array}{l}1.04 \\
0.232\end{array}$ & $\begin{array}{l}1.20 \\
0.111\end{array}$ & $\begin{array}{l}1.02 \\
0.250\end{array}$ & $\begin{array}{l}1.32 \\
0.062\end{array}$ \\
\hline $\begin{array}{l}y \text { Diff. } \\
p \text {-value }\end{array}$ & $\begin{array}{l}1.11 \\
0.168\end{array}$ & $\begin{array}{l}1.29 \\
0.072\end{array}$ & $\begin{array}{l}1.07 \\
0.201\end{array}$ & $\begin{array}{l}1.06 \\
0.215\end{array}$ & $\begin{array}{l}0.67 \\
0.753\end{array}$ & $\begin{array}{l}0.93 \\
0.357\end{array}$ & $\begin{array}{l}0.89 \\
0.403\end{array}$ & $\begin{array}{l}0.74 \\
0.638\end{array}$ & $\begin{array}{l}0.84 \\
0.483\end{array}$ & $\begin{array}{l}1.17 \\
0.129\end{array}$ \\
\hline \multicolumn{11}{|c|}{ All Stocks, 1992 to 1996} \\
\hline $\begin{array}{l}\gamma \\
p \text {-value }\end{array}$ & $\begin{array}{l}1.50 \\
0.022\end{array}$ & $\begin{array}{l}1.31 \\
0.066\end{array}$ & $\begin{array}{l}1.05 \\
0.222\end{array}$ & $\begin{array}{l}1.89 \\
0.002\end{array}$ & $\begin{array}{l}1.27 \\
0.078\end{array}$ & $\begin{array}{l}0.94 \\
0.343\end{array}$ & $\begin{array}{l}1.23 \\
0.095\end{array}$ & $\begin{array}{l}0.66 \\
0.782\end{array}$ & $\begin{array}{l}1.72 \\
0.005\end{array}$ & $\begin{array}{l}1.54 \\
0.018\end{array}$ \\
\hline $\begin{array}{l}\gamma \tau(\nu) \\
p \text {-value }\end{array}$ & $\begin{array}{l}0.87 \\
0.443\end{array}$ & $\begin{array}{l}1.05 \\
0.218\end{array}$ & $\begin{array}{l}0.60 \\
0.858\end{array}$ & $\begin{array}{l}0.89 \\
0.404\end{array}$ & $\begin{array}{l}1.11 \\
0.174\end{array}$ & $\begin{array}{l}1.03 \\
0.242\end{array}$ & $\begin{array}{l}0.90 \\
0.390\end{array}$ & $\begin{array}{l}0.65 \\
0.787\end{array}$ & $\begin{array}{l}0.99 \\
0.283\end{array}$ & $\begin{array}{l}1.12 \\
0.165\end{array}$ \\
\hline $\begin{array}{l}\gamma \tau(\lambda) \\
p \text {-value }\end{array}$ & $\begin{array}{l}0.72 \\
0.670\end{array}$ & $\begin{array}{l}0.66 \\
0.778\end{array}$ & $\begin{array}{l}0.75 \\
0.624\end{array}$ & $\begin{array}{l}1.42 \\
0.036\end{array}$ & $\begin{array}{l}1.02 \\
0.246\end{array}$ & $\begin{array}{l}0.58 \\
0.895\end{array}$ & $\begin{array}{l}0.61 \\
0.854\end{array}$ & $\begin{array}{l}0.64 \\
0.813\end{array}$ & $\begin{array}{l}1.36 \\
0.048\end{array}$ & $\begin{array}{l}0.93 \\
0.357\end{array}$ \\
\hline $\begin{array}{l}\gamma \text { Diff. } \\
p \text {-value }\end{array}$ & $\begin{array}{l}0.58 \\
0.887\end{array}$ & $\begin{array}{l}0.88 \\
0.422\end{array}$ & $\begin{array}{l}0.50 \\
0.966\end{array}$ & $\begin{array}{l}0.49 \\
0.971\end{array}$ & $\begin{array}{l}0.43 \\
0.993\end{array}$ & $\begin{array}{l}0.81 \\
0.528\end{array}$ & $\begin{array}{l}0.60 \\
0.858\end{array}$ & $\begin{array}{l}0.46 \\
0.984\end{array}$ & $\begin{array}{l}0.96 \\
0.314\end{array}$ & $\begin{array}{l}0.99 \\
0.282\end{array}$ \\
\hline
\end{tabular}




\section{Table VIII}

Kolmogorov-Smirnov test of the equality of conditional and unconditional 1-day return distributions for NASDAQ stocks from 1962 to 1996, in 5-year subperiods, and in size quintiles. Conditional returns are defined as the daily return three days following the conclusion of an occurrence of one of 10 technical indicators: head-and-shoulders (HS), inverted head-and-shoulders (IHS), broadening top (BTOP), broadening bottom (BBOT), triangle top (TTOP), triangle bottom (TBOT), rectangle top (RTOP), rectangle bottom (RBOT), double top (DTOP), and double bottom (DBOT). All returns have been normalized by subtraction of their means and division by their standard deviations. $p$-values are with respect to the asymptotic distribution of the Kolmogorov-Smirnov test statistic. The symbols ' $\tau(\searrow)$ ' and ' $\tau(\lambda)$ ' indicate that the conditional distribution is also conditioned on decreasing and increasing volume trend, respectively.

\begin{tabular}{|c|c|c|c|c|c|c|c|c|c|c|}
\hline Statistic & HS & IHS & BTOP & BBOT & TTOP & TBOT & RTOP & RBOT & DTOP & DBOT \\
\hline \multicolumn{11}{|c|}{ All Stocks, 1962 to 1996} \\
\hline $\begin{array}{l}\gamma \\
p \text {-value }\end{array}$ & $\begin{array}{l}2.31 \\
0.000\end{array}$ & $\begin{array}{l}2.68 \\
0.000\end{array}$ & $\begin{array}{l}1.60 \\
0.012\end{array}$ & $\begin{array}{l}1.84 \\
0.002\end{array}$ & $\begin{array}{l}2.81 \\
0.000\end{array}$ & $\begin{array}{l}2.34 \\
0.000\end{array}$ & $\begin{array}{l}2.69 \\
0.000\end{array}$ & $\begin{array}{l}1.90 \\
0.001\end{array}$ & $\begin{array}{l}2.29 \\
0.000\end{array}$ & $\begin{array}{l}2.06 \\
0.000\end{array}$ \\
\hline $\begin{array}{l}\gamma \tau(\searrow) \\
p \text {-value }\end{array}$ & $\begin{array}{l}1.86 \\
0.002\end{array}$ & $\begin{array}{l}1.53 \\
0.019\end{array}$ & $\begin{array}{l}1.35 \\
0.052\end{array}$ & $\begin{array}{l}0.99 \\
0.281\end{array}$ & $\begin{array}{l}1.97 \\
0.001\end{array}$ & $\begin{array}{l}1.95 \\
0.001\end{array}$ & $\begin{array}{l}2.16 \\
0.000\end{array}$ & $\begin{array}{l}1.73 \\
0.005\end{array}$ & $\begin{array}{l}1.38 \\
0.045\end{array}$ & $\begin{array}{l}1.94 \\
0.001\end{array}$ \\
\hline $\begin{array}{l}\gamma \tau(\lambda) \\
p \text {-value }\end{array}$ & $\begin{array}{l}1.59 \\
0.013\end{array}$ & $\begin{array}{l}2.10 \\
0.000\end{array}$ & $\begin{array}{l}1.82 \\
0.003\end{array}$ & $\begin{array}{l}1.59 \\
0.013\end{array}$ & $\begin{array}{l}1.89 \\
0.002\end{array}$ & $\begin{array}{l}1.18 \\
0.126\end{array}$ & $\begin{array}{l}1.57 \\
0.014\end{array}$ & $\begin{array}{l}1.22 \\
0.102\end{array}$ & $\begin{array}{l}2.15 \\
0.000\end{array}$ & $\begin{array}{l}1.46 \\
0.028\end{array}$ \\
\hline $\begin{array}{l}\gamma \text { Diff. } \\
p \text {-value }\end{array}$ & $\begin{array}{l}1.08 \\
0.195\end{array}$ & $\begin{array}{l}0.86 \\
0.450\end{array}$ & $\begin{array}{l}1.10 \\
0.175\end{array}$ & $\begin{array}{l}0.80 \\
0.542\end{array}$ & $\begin{array}{l}1.73 \\
0.005\end{array}$ & $\begin{array}{l}0.74 \\
0.637\end{array}$ & $\begin{array}{l}0.91 \\
0.379\end{array}$ & $\begin{array}{l}0.75 \\
0.621\end{array}$ & $\begin{array}{l}0.76 \\
0.619\end{array}$ & $\begin{array}{l}1.52 \\
0.020\end{array}$ \\
\hline
\end{tabular}




\section{Table VIII (continued)}

\begin{tabular}{|c|c|c|c|c|c|c|c|c|c|c|}
\hline Statistic & HS & IHS & BTOP & BBOT & TTOP & TВот & RTOP & RBOT & DTOP & DBOT \\
\hline \multicolumn{11}{|c|}{ Smallest Quintile, 1962 to 1996} \\
\hline $\begin{array}{l}\gamma \\
p \text {-value }\end{array}$ & $\begin{array}{l}1.51 \\
0.021\end{array}$ & $\begin{array}{l}2.16 \\
0.000\end{array}$ & $\begin{array}{l}1.72 \\
0.006\end{array}$ & $\begin{array}{l}1.68 \\
0.007\end{array}$ & $\begin{array}{l}1.22 \\
0.101\end{array}$ & $\begin{array}{l}1.55 \\
0.016\end{array}$ & $\begin{array}{l}2.13 \\
0.000\end{array}$ & $\begin{array}{l}1.70 \\
0.006\end{array}$ & $\begin{array}{l}1.74 \\
0.005\end{array}$ & $\begin{array}{l}1.98 \\
0.001\end{array}$ \\
\hline $\begin{array}{l}\gamma \tau(\rangle) \\
p \text {-value }\end{array}$ & $\begin{array}{l}1.16 \\
0.139\end{array}$ & $\begin{array}{l}1.30 \\
0.070\end{array}$ & $\begin{array}{l}0.85 \\
0.463\end{array}$ & $\begin{array}{l}1.14 \\
0.150\end{array}$ & $\begin{array}{l}1.25 \\
0.089\end{array}$ & $\begin{array}{l}1.62 \\
0.010\end{array}$ & $\begin{array}{l}1.43 \\
0.033\end{array}$ & $\begin{array}{l}1.05 \\
0.216\end{array}$ & $\begin{array}{l}1.08 \\
0.191\end{array}$ & $\begin{array}{l}1.95 \\
0.001\end{array}$ \\
\hline $\begin{array}{l}\gamma \tau(\lambda) \\
p \text {-value }\end{array}$ & $\begin{array}{l}0.85 \\
0.462\end{array}$ & $\begin{array}{l}1.73 \\
0.005\end{array}$ & $\begin{array}{l}1.61 \\
0.012\end{array}$ & $\begin{array}{l}2.00 \\
0.001\end{array}$ & $\begin{array}{l}1.34 \\
0.055\end{array}$ & $\begin{array}{l}0.79 \\
0.553\end{array}$ & $\begin{array}{l}1.58 \\
0.014\end{array}$ & $\begin{array}{l}1.52 \\
0.019\end{array}$ & $\begin{array}{l}1.47 \\
0.026\end{array}$ & $\begin{array}{l}1.20 \\
0.115\end{array}$ \\
\hline $\begin{array}{l}\gamma \text { Diff. } \\
p \text {-value }\end{array}$ & $\begin{array}{l}1.04 \\
0.227\end{array}$ & $\begin{array}{l}0.95 \\
0.334\end{array}$ & $\begin{array}{l}0.83 \\
0.493\end{array}$ & $\begin{array}{l}1.44 \\
0.031\end{array}$ & $\begin{array}{l}1.39 \\
0.042\end{array}$ & $\begin{array}{l}0.78 \\
0.574\end{array}$ & $\begin{array}{l}0.95 \\
0.326\end{array}$ & $\begin{array}{l}0.73 \\
0.654\end{array}$ & $\begin{array}{l}0.94 \\
0.338\end{array}$ & $\begin{array}{l}1.09 \\
0.184\end{array}$ \\
\hline \multicolumn{11}{|c|}{ 2nd Quintile, 1962 to 1996} \\
\hline $\begin{array}{l}\gamma \\
p \text {-value }\end{array}$ & $\begin{array}{l}1.55 \\
0.016\end{array}$ & $\begin{array}{l}1.46 \\
0.029\end{array}$ & $\begin{array}{l}0.94 \\
0.341\end{array}$ & $\begin{array}{l}1.44 \\
0.031\end{array}$ & $\begin{array}{l}1.24 \\
0.095\end{array}$ & $\begin{array}{l}1.08 \\
0.192\end{array}$ & $\begin{array}{l}1.20 \\
0.113\end{array}$ & $\begin{array}{l}1.10 \\
0.175\end{array}$ & $\begin{array}{l}1.90 \\
0.001\end{array}$ & $\begin{array}{l}1.27 \\
0.078\end{array}$ \\
\hline $\begin{array}{l}\gamma \tau(\searrow) \\
p \text {-value }\end{array}$ & $\begin{array}{l}1.11 \\
0.173\end{array}$ & $\begin{array}{l}1.13 \\
0.157\end{array}$ & $\begin{array}{l}1.08 \\
0.192\end{array}$ & $\begin{array}{l}0.92 \\
0.371\end{array}$ & $\begin{array}{l}1.23 \\
0.097\end{array}$ & $\begin{array}{l}0.79 \\
0.557\end{array}$ & $\begin{array}{l}1.34 \\
0.055\end{array}$ & $\begin{array}{l}1.19 \\
0.117\end{array}$ & $\begin{array}{l}1.09 \\
0.185\end{array}$ & $\begin{array}{l}1.61 \\
0.011\end{array}$ \\
\hline $\begin{array}{l}\gamma \tau(\lambda) \\
p \text {-value }\end{array}$ & $\begin{array}{l}1.37 \\
0.048\end{array}$ & $\begin{array}{l}0.87 \\
0.439\end{array}$ & $\begin{array}{l}0.73 \\
0.665\end{array}$ & $\begin{array}{l}0.97 \\
0.309\end{array}$ & $\begin{array}{l}1.38 \\
0.044\end{array}$ & $\begin{array}{l}1.29 \\
0.073\end{array}$ & $\begin{array}{l}1.12 \\
0.162\end{array}$ & $\begin{array}{l}0.91 \\
0.381\end{array}$ & $\begin{array}{l}1.12 \\
0.165\end{array}$ & $\begin{array}{l}0.94 \\
0.343\end{array}$ \\
\hline $\begin{array}{l}\gamma \text { Diff. } \\
p \text {-value }\end{array}$ & $\begin{array}{l}1.23 \\
0.095\end{array}$ & $\begin{array}{l}0.62 \\
0.835\end{array}$ & $\begin{array}{l}0.97 \\
0.309\end{array}$ & $\begin{array}{l}0.69 \\
0.733\end{array}$ & $\begin{array}{l}1.02 \\
0.248\end{array}$ & $\begin{array}{l}1.05 \\
0.224\end{array}$ & $\begin{array}{l}1.09 \\
0.183\end{array}$ & $\begin{array}{l}0.78 \\
0.579\end{array}$ & $\begin{array}{l}0.58 \\
0.894\end{array}$ & $\begin{array}{l}0.51 \\
0.955\end{array}$ \\
\hline \multicolumn{11}{|c|}{ 3rd Quintile, 1962 to 1996} \\
\hline $\begin{array}{l}\gamma \\
p \text {-value }\end{array}$ & $\begin{array}{l}1.25 \\
0.087\end{array}$ & $\begin{array}{l}1.72 \\
0.005\end{array}$ & $\begin{array}{l}0.82 \\
0.510\end{array}$ & $\begin{array}{l}1.71 \\
0.006\end{array}$ & $\begin{array}{l}1.41 \\
0.038\end{array}$ & $\begin{array}{l}1.52 \\
0.020\end{array}$ & $\begin{array}{l}1.25 \\
0.089\end{array}$ & $\begin{array}{l}1.84 \\
0.002\end{array}$ & $\begin{array}{l}1.86 \\
0.002\end{array}$ & $\begin{array}{l}1.82 \\
0.003\end{array}$ \\
\hline $\begin{array}{l}\gamma \tau(\rangle) \\
p \text {-value }\end{array}$ & $\begin{array}{l}0.93 \\
0.348\end{array}$ & $\begin{array}{l}1.08 \\
0.194\end{array}$ & $\begin{array}{l}0.54 \\
0.930\end{array}$ & $\begin{array}{l}1.23 \\
0.097\end{array}$ & $\begin{array}{l}1.06 \\
0.213\end{array}$ & $\begin{array}{l}1.02 \\
0.245\end{array}$ & $\begin{array}{l}0.79 \\
0.560\end{array}$ & $\begin{array}{l}1.47 \\
0.026\end{array}$ & $\begin{array}{l}1.38 \\
0.044\end{array}$ & $\begin{array}{l}0.88 \\
0.423\end{array}$ \\
\hline $\begin{array}{c}\gamma \tau(\lambda) \\
p \text {-value }\end{array}$ & $\begin{array}{l}0.59 \\
0.873\end{array}$ & $\begin{array}{l}1.14 \\
0.146\end{array}$ & $\begin{array}{l}0.97 \\
0.309\end{array}$ & $\begin{array}{l}1.37 \\
0.047\end{array}$ & $\begin{array}{l}0.75 \\
0.633\end{array}$ & $\begin{array}{l}1.01 \\
0.262\end{array}$ & $\begin{array}{l}1.13 \\
0.159\end{array}$ & $\begin{array}{l}1.34 \\
0.054\end{array}$ & $\begin{array}{l}1.37 \\
0.047\end{array}$ & $\begin{array}{l}1.78 \\
0.003\end{array}$ \\
\hline $\begin{array}{l}\gamma \text { Diff. } \\
p \text {-value }\end{array}$ & $\begin{array}{l}0.61 \\
0.852\end{array}$ & $\begin{array}{l}0.89 \\
0.405\end{array}$ & $\begin{array}{l}0.58 \\
0.890\end{array}$ & $\begin{array}{l}0.46 \\
0.984\end{array}$ & $\begin{array}{l}0.61 \\
0.844\end{array}$ & $\begin{array}{l}0.89 \\
0.404\end{array}$ & $\begin{array}{l}0.52 \\
0.947\end{array}$ & $\begin{array}{l}0.38 \\
0.999\end{array}$ & $\begin{array}{l}0.60 \\
0.864\end{array}$ & $\begin{array}{l}1.09 \\
0.188\end{array}$ \\
\hline \multicolumn{11}{|c|}{ 4th Quintile, 1962 to 1996} \\
\hline $\begin{array}{l}\gamma \\
p \text {-value }\end{array}$ & $\begin{array}{l}1.04 \\
0.233\end{array}$ & $\begin{array}{l}0.82 \\
0.510\end{array}$ & $\begin{array}{l}1.20 \\
0.111\end{array}$ & $\begin{array}{l}0.98 \\
0.298\end{array}$ & $\begin{array}{l}1.30 \\
0.067\end{array}$ & $\begin{array}{l}1.25 \\
0.087\end{array}$ & $\begin{array}{l}1.88 \\
0.002\end{array}$ & $\begin{array}{l}0.79 \\
0.553\end{array}$ & $\begin{array}{l}0.94 \\
0.341\end{array}$ & $\begin{array}{l}0.66 \\
0.779\end{array}$ \\
\hline $\begin{array}{l}\gamma \tau(\rangle) \\
p \text {-value }\end{array}$ & $\begin{array}{l}0.81 \\
0.528\end{array}$ & $\begin{array}{l}0.54 \\
0.935\end{array}$ & $\begin{array}{l}0.57 \\
0.897\end{array}$ & $\begin{array}{l}1.05 \\
0.217\end{array}$ & $\begin{array}{l}0.92 \\
0.367\end{array}$ & $\begin{array}{l}1.06 \\
0.215\end{array}$ & $\begin{array}{l}1.23 \\
0.097\end{array}$ & $\begin{array}{l}0.72 \\
0.672\end{array}$ & $\begin{array}{l}1.53 \\
0.019\end{array}$ & $\begin{array}{l}0.87 \\
0.431\end{array}$ \\
\hline $\begin{array}{l}\gamma \tau(\lambda) \\
p \text {-value }\end{array}$ & $\begin{array}{l}0.97 \\
0.306\end{array}$ & $\begin{array}{l}1.04 \\
0.229\end{array}$ & $\begin{array}{l}1.29 \\
0.071\end{array}$ & $\begin{array}{l}0.53 \\
0.938\end{array}$ & $\begin{array}{l}2.25 \\
0.000\end{array}$ & $\begin{array}{l}0.71 \\
0.696\end{array}$ & $\begin{array}{l}1.05 \\
0.219\end{array}$ & $\begin{array}{l}0.77 \\
0.589\end{array}$ & $\begin{array}{l}1.20 \\
0.114\end{array}$ & $\begin{array}{l}0.97 \\
0.309\end{array}$ \\
\hline $\begin{array}{l}\gamma \text { Diff. } \\
p \text {-value }\end{array}$ & $\begin{array}{l}1.17 \\
0.128\end{array}$ & $\begin{array}{l}0.89 \\
0.400\end{array}$ & $\begin{array}{l}0.98 \\
0.292\end{array}$ & $\begin{array}{l}0.97 \\
0.301\end{array}$ & $\begin{array}{l}1.86 \\
0.002\end{array}$ & $\begin{array}{l}0.62 \\
0.843\end{array}$ & $\begin{array}{l}0.93 \\
0.352\end{array}$ & $\begin{array}{l}0.73 \\
0.653\end{array}$ & $\begin{array}{l}1.31 \\
0.065\end{array}$ & $\begin{array}{l}0.92 \\
0.371\end{array}$ \\
\hline \multicolumn{11}{|c|}{ Largest Quintile, 1962 to 1996} \\
\hline $\begin{array}{l}\gamma \\
p \text {-value }\end{array}$ & $\begin{array}{l}1.08 \\
0.190\end{array}$ & $\begin{array}{l}1.01 \\
0.255\end{array}$ & $\begin{array}{l}1.03 \\
0.242\end{array}$ & $\begin{array}{l}0.66 \\
0.778\end{array}$ & $\begin{array}{l}0.92 \\
0.360\end{array}$ & $\begin{array}{l}0.68 \\
0.742\end{array}$ & $\begin{array}{l}0.85 \\
0.462\end{array}$ & $\begin{array}{l}1.16 \\
0.137\end{array}$ & $\begin{array}{l}1.14 \\
0.150\end{array}$ & $\begin{array}{l}0.67 \\
0.756\end{array}$ \\
\hline $\begin{array}{l}\gamma \tau(\nu) \\
p \text {-value }\end{array}$ & $\begin{array}{l}1.03 \\
0.237\end{array}$ & $\begin{array}{l}0.54 \\
0.931\end{array}$ & $\begin{array}{l}0.93 \\
0.356\end{array}$ & $\begin{array}{l}0.47 \\
0.981\end{array}$ & $\begin{array}{l}0.77 \\
0.587\end{array}$ & $\begin{array}{l}0.76 \\
0.612\end{array}$ & $\begin{array}{l}0.85 \\
0.468\end{array}$ & $\begin{array}{l}0.62 \\
0.840\end{array}$ & $\begin{array}{l}0.85 \\
0.465\end{array}$ & $\begin{array}{l}1.14 \\
0.149\end{array}$ \\
\hline $\begin{array}{l}\gamma \tau(\lambda) \\
p \text {-value }\end{array}$ & $\begin{array}{l}1.18 \\
0.123\end{array}$ & $\begin{array}{l}1.39 \\
0.041\end{array}$ & $\begin{array}{l}0.50 \\
0.967\end{array}$ & $\begin{array}{l}0.93 \\
0.358\end{array}$ & $\begin{array}{l}0.88 \\
0.415\end{array}$ & $\begin{array}{l}1.25 \\
0.089\end{array}$ & $\begin{array}{l}0.77 \\
0.597\end{array}$ & $\begin{array}{l}1.13 \\
0.156\end{array}$ & $\begin{array}{l}0.98 \\
0.292\end{array}$ & $\begin{array}{l}1.12 \\
0.160\end{array}$ \\
\hline $\begin{array}{l}\gamma \text { Diff. } \\
p \text {-value }\end{array}$ & $\begin{array}{l}0.94 \\
0.342\end{array}$ & $\begin{array}{l}1.25 \\
0.090\end{array}$ & $\begin{array}{l}0.73 \\
0.668\end{array}$ & $\begin{array}{l}0.84 \\
0.476\end{array}$ & $\begin{array}{l}0.76 \\
0.617\end{array}$ & $\begin{array}{l}1.11 \\
0.169\end{array}$ & $\begin{array}{l}0.73 \\
0.662\end{array}$ & $\begin{array}{l}0.86 \\
0.457\end{array}$ & $\begin{array}{l}0.86 \\
0.454\end{array}$ & $\begin{array}{l}0.77 \\
0.598\end{array}$ \\
\hline
\end{tabular}


Table VIII (continued)

\begin{tabular}{|c|c|c|c|c|c|c|c|c|c|c|}
\hline Statistic & HS & IHS & BTOP & BBOT & TTOP & ТВОТ & RTOP & RBOT & DTOP & DBOT \\
\hline \multicolumn{11}{|c|}{ All Stocks, 1962 to 1966} \\
\hline $\begin{array}{l}\gamma \\
p \text {-value }\end{array}$ & $\begin{array}{l}1.01 \\
0.261\end{array}$ & $\begin{array}{l}0.84 \\
0.481\end{array}$ & $\begin{array}{l}1.08 \\
0.193\end{array}$ & $\begin{array}{l}0.82 \\
0.508\end{array}$ & $\begin{array}{l}0.71 \\
0.697\end{array}$ & $\begin{array}{l}0.70 \\
0.718\end{array}$ & $\begin{array}{l}1.59 \\
0.013\end{array}$ & $\begin{array}{l}0.89 \\
0.411\end{array}$ & $\begin{array}{l}1.12 \\
0.166\end{array}$ & $\begin{array}{l}1.10 \\
0.175\end{array}$ \\
\hline $\begin{array}{l}\gamma \tau(\Delta) \\
p \text {-value }\end{array}$ & $\begin{array}{l}0.95 \\
0.322\end{array}$ & $\begin{array}{l}0.65 \\
0.798\end{array}$ & $\begin{array}{l}0.41 \\
0.997\end{array}$ & $\begin{array}{l}1.05 \\
0.224\end{array}$ & $\begin{array}{l}0.51 \\
0.956\end{array}$ & $\begin{array}{l}1.13 \\
0.155\end{array}$ & $\begin{array}{l}0.79 \\
0.556\end{array}$ & $\begin{array}{l}0.93 \\
0.350\end{array}$ & $\begin{array}{l}0.93 \\
0.350\end{array}$ & $\begin{array}{l}1.21 \\
0.108\end{array}$ \\
\hline $\begin{array}{l}\gamma \tau(\lambda) \\
p \text {-value }\end{array}$ & $\begin{array}{l}0.77 \\
0.586\end{array}$ & $\begin{array}{l}0.96 \\
0.314\end{array}$ & $\begin{array}{l}0.83 \\
0.489\end{array}$ & $\begin{array}{l}0.73 \\
0.663\end{array}$ & $\begin{array}{l}1.35 \\
0.052\end{array}$ & $\begin{array}{l}0.49 \\
0.972\end{array}$ & $\begin{array}{l}1.17 \\
0.130\end{array}$ & $\begin{array}{l}0.62 \\
0.843\end{array}$ & $\begin{array}{l}1.18 \\
0.121\end{array}$ & $\begin{array}{l}1.15 \\
0.140\end{array}$ \\
\hline $\begin{array}{l}\gamma \text { Diff. } \\
p \text {-value }\end{array}$ & $\begin{array}{l}1.10 \\
0.174\end{array}$ & $\begin{array}{l}0.67 \\
0.761\end{array}$ & $\begin{array}{l}0.32 \\
1.000\end{array}$ & $\begin{array}{l}0.69 \\
0.735\end{array}$ & $\begin{array}{l}1.29 \\
0.071\end{array}$ & $\begin{array}{l}0.58 \\
0.892\end{array}$ & $\begin{array}{l}0.80 \\
0.551\end{array}$ & $\begin{array}{l}0.75 \\
0.620\end{array}$ & $\begin{array}{l}0.98 \\
0.298\end{array}$ & $\begin{array}{l}1.06 \\
0.208\end{array}$ \\
\hline \multicolumn{11}{|c|}{ All Stocks, 1967 to 1971} \\
\hline $\begin{array}{l}\gamma \\
p \text {-value }\end{array}$ & $\begin{array}{l}0.75 \\
0.636\end{array}$ & $\begin{array}{l}1.10 \\
0.175\end{array}$ & $\begin{array}{l}1.00 \\
0.273\end{array}$ & $\begin{array}{l}0.74 \\
0.637\end{array}$ & $\begin{array}{l}1.27 \\
0.079\end{array}$ & $\begin{array}{l}1.35 \\
0.052\end{array}$ & $\begin{array}{l}1.16 \\
0.136\end{array}$ & $\begin{array}{l}0.74 \\
0.642\end{array}$ & $\begin{array}{l}0.74 \\
0.638\end{array}$ & $\begin{array}{l}1.21 \\
0.107\end{array}$ \\
\hline $\begin{array}{l}\gamma \tau(\nu) \\
p \text {-value }\end{array}$ & $\begin{array}{l}1.03 \\
0.241\end{array}$ & $\begin{array}{l}0.52 \\
0.947\end{array}$ & $\begin{array}{l}0.70 \\
0.714\end{array}$ & $\begin{array}{l}0.87 \\
0.438\end{array}$ & $\begin{array}{l}1.24 \\
0.092\end{array}$ & $\begin{array}{l}1.33 \\
0.058\end{array}$ & $\begin{array}{l}1.29 \\
0.072\end{array}$ & $\begin{array}{l}0.83 \\
0.490\end{array}$ & $\begin{array}{l}0.72 \\
0.684\end{array}$ & $\begin{array}{l}1.45 \\
0.031\end{array}$ \\
\hline $\begin{array}{l}\gamma \tau(\lambda) \\
p \text {-value }\end{array}$ & $\begin{array}{l}1.05 \\
0.217\end{array}$ & $\begin{array}{l}1.08 \\
0.192\end{array}$ & $\begin{array}{l}1.12 \\
0.165\end{array}$ & $\begin{array}{l}0.64 \\
0.810\end{array}$ & $\begin{array}{l}0.79 \\
0.566\end{array}$ & $\begin{array}{l}0.65 \\
0.797\end{array}$ & $\begin{array}{l}0.55 \\
0.923\end{array}$ & $\begin{array}{l}0.53 \\
0.941\end{array}$ & $\begin{array}{l}0.75 \\
0.631\end{array}$ & $\begin{array}{l}0.69 \\
0.723\end{array}$ \\
\hline $\begin{array}{l}\gamma \text { Diff. } \\
p \text {-value }\end{array}$ & $\begin{array}{l}1.24 \\
0.093\end{array}$ & $\begin{array}{l}0.89 \\
0.413\end{array}$ & $\begin{array}{l}0.66 \\
0.770\end{array}$ & $\begin{array}{l}0.78 \\
0.585\end{array}$ & $\begin{array}{l}1.07 \\
0.203\end{array}$ & $\begin{array}{l}0.88 \\
0.418\end{array}$ & $\begin{array}{l}0.88 \\
0.423\end{array}$ & $\begin{array}{l}0.40 \\
0.997\end{array}$ & $\begin{array}{l}0.91 \\
0.385\end{array}$ & $\begin{array}{l}0.76 \\
0.602\end{array}$ \\
\hline \multicolumn{11}{|c|}{ All Stocks, 1972 to 1976} \\
\hline $\begin{array}{l}\gamma \\
p \text {-value }\end{array}$ & $\begin{array}{l}0.82 \\
0.509\end{array}$ & $\begin{array}{l}1.28 \\
0.077\end{array}$ & $\begin{array}{l}1.84 \\
0.002\end{array}$ & $\begin{array}{l}1.13 \\
0.156\end{array}$ & $\begin{array}{l}1.45 \\
0.029\end{array}$ & $\begin{array}{l}1.53 \\
0.019\end{array}$ & $\begin{array}{l}1.31 \\
0.064\end{array}$ & $\begin{array}{l}0.96 \\
0.314\end{array}$ & $\begin{array}{l}0.85 \\
0.464\end{array}$ & $\begin{array}{l}1.76 \\
0.004\end{array}$ \\
\hline$\underset{p \text {-value }}{\gamma \tau(\mathrm{x})}$ & $\begin{array}{l}0.59 \\
0.875\end{array}$ & $\begin{array}{l}0.73 \\
0.669\end{array}$ & $\begin{array}{r}-99.00 \\
0.000\end{array}$ & $\begin{array}{l}0.91 \\
0.376\end{array}$ & $\begin{array}{l}1.39 \\
0.042\end{array}$ & $\begin{array}{l}0.73 \\
0.654\end{array}$ & $\begin{array}{l}1.37 \\
0.046\end{array}$ & $\begin{array}{l}0.98 \\
0.292\end{array}$ & $\begin{array}{l}1.22 \\
0.100\end{array}$ & $\begin{array}{l}0.94 \\
0.344\end{array}$ \\
\hline $\begin{array}{l}\gamma \tau(\lambda) \\
p \text {-value }\end{array}$ & $\begin{array}{l}0.65 \\
0.800\end{array}$ & $\begin{array}{l}0.73 \\
0.653\end{array}$ & $\begin{array}{r}-99.00 \\
0.000\end{array}$ & $\begin{array}{r}-99.00 \\
0.000\end{array}$ & $\begin{array}{c}-99.00 \\
0.000\end{array}$ & $\begin{array}{r}-99.00 \\
0.000\end{array}$ & $\begin{array}{l}0.59 \\
0.878\end{array}$ & $\begin{array}{l}0.76 \\
0.611\end{array}$ & $\begin{array}{l}0.78 \\
0.573\end{array}$ & $\begin{array}{l}0.65 \\
0.798\end{array}$ \\
\hline $\begin{array}{l}\gamma \text { Diff. } \\
p \text {-value }\end{array}$ & $\begin{array}{l}0.48 \\
0.974\end{array}$ & $\begin{array}{l}0.57 \\
0.902\end{array}$ & $\begin{array}{c}-99.00 \\
0.000\end{array}$ & $\begin{array}{c}-99.00 \\
0.000\end{array}$ & $\begin{array}{c}-99.00 \\
0.000\end{array}$ & $\begin{array}{c}-99.00 \\
0.000\end{array}$ & $\begin{array}{l}0.63 \\
0.828\end{array}$ & $\begin{array}{l}0.55 \\
0.925\end{array}$ & $\begin{array}{l}0.92 \\
0.362\end{array}$ & $\begin{array}{l}0.37 \\
0.999\end{array}$ \\
\hline \multicolumn{11}{|c|}{ All Stocks, 1977 to 1981} \\
\hline $\begin{array}{l}\gamma \\
p \text {-value }\end{array}$ & $\begin{array}{l}1.35 \\
0.053\end{array}$ & $\begin{array}{l}1.40 \\
0.039\end{array}$ & $\begin{array}{l}1.03 \\
0.236\end{array}$ & $\begin{array}{l}1.02 \\
0.249\end{array}$ & $\begin{array}{l}1.55 \\
0.016\end{array}$ & $\begin{array}{l}2.07 \\
0.000\end{array}$ & $\begin{array}{l}0.74 \\
0.636\end{array}$ & $\begin{array}{l}0.62 \\
0.842\end{array}$ & $\begin{array}{l}0.92 \\
0.369\end{array}$ & $\begin{array}{l}1.28 \\
0.077\end{array}$ \\
\hline $\begin{array}{l}\gamma \tau(\mathrm{\tau}) \\
p \text {-value }\end{array}$ & $\begin{array}{l}1.19 \\
0.117\end{array}$ & $\begin{array}{l}1.47 \\
0.027\end{array}$ & $\begin{array}{r}-99.00 \\
0.000\end{array}$ & $\begin{array}{c}-99.00 \\
0.000\end{array}$ & $\begin{array}{l}0.96 \\
0.317\end{array}$ & $\begin{array}{l}0.98 \\
0.290\end{array}$ & $\begin{array}{l}0.86 \\
0.453\end{array}$ & $\begin{array}{l}0.79 \\
0.554\end{array}$ & $\begin{array}{l}0.81 \\
0.522\end{array}$ & $\begin{array}{l}0.68 \\
0.748\end{array}$ \\
\hline $\begin{array}{l}\gamma \tau(\lambda) \\
p \text {-value }\end{array}$ & $\begin{array}{l}0.69 \\
0.728\end{array}$ & $\begin{array}{l}0.94 \\
0.341\end{array}$ & $\begin{array}{l}0.80 \\
0.542\end{array}$ & $\begin{array}{r}-99.00 \\
0.000\end{array}$ & $\begin{array}{l}1.46 \\
0.028\end{array}$ & $\begin{array}{r}-99.00 \\
0.000\end{array}$ & $\begin{array}{l}0.56 \\
0.918\end{array}$ & $\begin{array}{l}0.82 \\
0.514\end{array}$ & $\begin{array}{l}1.06 \\
0.207\end{array}$ & $\begin{array}{l}0.94 \\
0.336\end{array}$ \\
\hline $\begin{array}{l}\gamma \text { Diff. } \\
p \text {-value }\end{array}$ & $\begin{array}{l}0.73 \\
0.665\end{array}$ & $\begin{array}{l}0.90 \\
0.395\end{array}$ & $\begin{array}{r}-99.00 \\
0.000\end{array}$ & $\begin{array}{r}-99.00 \\
0.000\end{array}$ & $\begin{array}{l}0.35 \\
1.000\end{array}$ & $\begin{array}{r}-99.00 \\
0.000\end{array}$ & $\begin{array}{l}0.44 \\
0.991\end{array}$ & $\begin{array}{l}0.37 \\
0.999\end{array}$ & $\begin{array}{l}0.80 \\
0.541\end{array}$ & $\begin{array}{l}0.53 \\
0.944\end{array}$ \\
\hline
\end{tabular}


Table VIII (continued)

\begin{tabular}{|c|c|c|c|c|c|c|c|c|c|c|}
\hline Statistic & HS & IHS & BTOP & BBOT & TTOP & ТВот & RTOP & RBOT & DTOP & DBOT \\
\hline \multicolumn{11}{|c|}{ All Stocks, 1982 to 1986} \\
\hline $\begin{array}{l}\gamma \\
p \text {-value }\end{array}$ & $\begin{array}{l}1.66 \\
0.008\end{array}$ & $\begin{array}{l}1.59 \\
0.013\end{array}$ & $\begin{array}{l}1.17 \\
0.129\end{array}$ & $\begin{array}{l}0.73 \\
0.654\end{array}$ & $\begin{array}{l}1.46 \\
0.028\end{array}$ & $\begin{array}{l}1.69 \\
0.006\end{array}$ & $\begin{array}{l}1.04 \\
0.232\end{array}$ & $\begin{array}{l}1.24 \\
0.093\end{array}$ & $\begin{array}{l}2.44 \\
0.000\end{array}$ & $\begin{array}{l}1.27 \\
0.078\end{array}$ \\
\hline $\begin{array}{l}\gamma \tau(\nu) \\
p \text {-value }\end{array}$ & $\begin{array}{l}1.65 \\
0.009\end{array}$ & $\begin{array}{l}1.10 \\
0.176\end{array}$ & $\begin{array}{l}0.46 \\
0.984\end{array}$ & $\begin{array}{l}0.74 \\
0.641\end{array}$ & $\begin{array}{l}0.95 \\
0.330\end{array}$ & $\begin{array}{l}1.47 \\
0.027\end{array}$ & $\begin{array}{l}0.83 \\
0.503\end{array}$ & $\begin{array}{l}1.18 \\
0.121\end{array}$ & $\begin{array}{l}1.20 \\
0.112\end{array}$ & $\begin{array}{l}0.59 \\
0.873\end{array}$ \\
\hline $\begin{array}{c}\gamma \tau(\lambda) \\
p \text {-value }\end{array}$ & $\begin{array}{l}1.13 \\
0.153\end{array}$ & $\begin{array}{l}1.31 \\
0.065\end{array}$ & $\begin{array}{l}0.86 \\
0.445\end{array}$ & $\begin{array}{l}0.42 \\
0.995\end{array}$ & $\begin{array}{l}1.17 \\
0.129\end{array}$ & $\begin{array}{l}1.04 \\
0.231\end{array}$ & $\begin{array}{l}0.97 \\
0.302\end{array}$ & $\begin{array}{l}1.13 \\
0.155\end{array}$ & $\begin{array}{l}1.68 \\
0.007\end{array}$ & $\begin{array}{l}0.89 \\
0.405\end{array}$ \\
\hline $\begin{array}{l}\gamma \text { Diff. } \\
p \text {-value }\end{array}$ & $\begin{array}{l}0.67 \\
0.755\end{array}$ & $\begin{array}{l}0.39 \\
0.998\end{array}$ & $\begin{array}{l}0.51 \\
0.957\end{array}$ & $\begin{array}{l}0.42 \\
0.994\end{array}$ & $\begin{array}{l}0.85 \\
0.462\end{array}$ & $\begin{array}{l}0.43 \\
0.993\end{array}$ & $\begin{array}{l}0.41 \\
0.996\end{array}$ & $\begin{array}{l}0.67 \\
0.766\end{array}$ & $\begin{array}{l}0.66 \\
0.782\end{array}$ & $\begin{array}{l}0.75 \\
0.627\end{array}$ \\
\hline \multicolumn{11}{|c|}{ All Stocks, 1987 to 1991} \\
\hline $\begin{array}{l}\gamma \\
p \text {-value }\end{array}$ & $\begin{array}{l}1.24 \\
0.091\end{array}$ & $\begin{array}{l}1.29 \\
0.070\end{array}$ & $\begin{array}{l}0.91 \\
0.384\end{array}$ & $\begin{array}{l}0.88 \\
0.421\end{array}$ & $\begin{array}{l}1.28 \\
0.074\end{array}$ & $\begin{array}{l}1.41 \\
0.039\end{array}$ & $\begin{array}{l}2.01 \\
0.001\end{array}$ & $\begin{array}{l}1.49 \\
0.024\end{array}$ & $\begin{array}{l}1.55 \\
0.017\end{array}$ & $\begin{array}{l}1.53 \\
0.019\end{array}$ \\
\hline $\begin{array}{l}\gamma \tau(\nu) \\
p \text {-value }\end{array}$ & $\begin{array}{l}1.05 \\
0.221\end{array}$ & $\begin{array}{l}1.00 \\
0.266\end{array}$ & $\begin{array}{l}1.00 \\
0.274\end{array}$ & $\begin{array}{l}0.78 \\
0.580\end{array}$ & $\begin{array}{l}1.68 \\
0.007\end{array}$ & $\begin{array}{l}0.92 \\
0.369\end{array}$ & $\begin{array}{l}1.67 \\
0.008\end{array}$ & $\begin{array}{l}1.25 \\
0.087\end{array}$ & $\begin{array}{l}0.61 \\
0.849\end{array}$ & $\begin{array}{l}0.86 \\
0.448\end{array}$ \\
\hline $\begin{array}{l}\gamma \tau(\mu) \\
p \text {-value }\end{array}$ & $\begin{array}{l}1.23 \\
0.099\end{array}$ & $\begin{array}{l}1.26 \\
0.084\end{array}$ & $\begin{array}{l}1.06 \\
0.208\end{array}$ & $\begin{array}{l}1.32 \\
0.060\end{array}$ & $\begin{array}{l}0.65 \\
0.787\end{array}$ & $\begin{array}{l}1.27 \\
0.078\end{array}$ & $\begin{array}{l}1.10 \\
0.176\end{array}$ & $\begin{array}{l}1.26 \\
0.085\end{array}$ & $\begin{array}{l}1.67 \\
0.007\end{array}$ & $\begin{array}{l}1.81 \\
0.003\end{array}$ \\
\hline $\begin{array}{l}\gamma \text { Diff. } \\
p \text {-value }\end{array}$ & $\begin{array}{l}0.80 \\
0.552\end{array}$ & $\begin{array}{l}0.91 \\
0.375\end{array}$ & $\begin{array}{l}1.22 \\
0.103\end{array}$ & $\begin{array}{l}1.28 \\
0.075\end{array}$ & $\begin{array}{l}1.22 \\
0.102\end{array}$ & $\begin{array}{l}0.92 \\
0.360\end{array}$ & $\begin{array}{l}0.87 \\
0.431\end{array}$ & $\begin{array}{l}0.81 \\
0.520\end{array}$ & $\begin{array}{l}1.07 \\
0.202\end{array}$ & $\begin{array}{l}1.05 \\
0.217\end{array}$ \\
\hline \multicolumn{11}{|c|}{ All Stocks, 1992 to 1996} \\
\hline $\begin{array}{l}\gamma \\
p \text {-value }\end{array}$ & $\begin{array}{l}1.21 \\
0.108\end{array}$ & $\begin{array}{l}1.61 \\
0.011\end{array}$ & $\begin{array}{l}0.84 \\
0.476\end{array}$ & $\begin{array}{l}0.90 \\
0.394\end{array}$ & $\begin{array}{l}0.97 \\
0.299\end{array}$ & $\begin{array}{l}0.91 \\
0.379\end{array}$ & $\begin{array}{l}1.60 \\
0.012\end{array}$ & $\begin{array}{l}1.51 \\
0.021\end{array}$ & $\begin{array}{l}1.13 \\
0.156\end{array}$ & $\begin{array}{l}1.00 \\
0.265\end{array}$ \\
\hline $\begin{array}{l}\gamma \tau(\nu) \\
p \text {-value }\end{array}$ & $\begin{array}{l}0.68 \\
0.752\end{array}$ & $\begin{array}{l}1.02 \\
0.246\end{array}$ & $\begin{array}{l}0.81 \\
0.530\end{array}$ & $\begin{array}{l}0.78 \\
0.578\end{array}$ & $\begin{array}{l}0.81 \\
0.532\end{array}$ & $\begin{array}{l}0.93 \\
0.357\end{array}$ & $\begin{array}{l}0.79 \\
0.558\end{array}$ & $\begin{array}{l}1.07 \\
0.201\end{array}$ & $\begin{array}{l}0.94 \\
0.340\end{array}$ & $\begin{array}{l}0.64 \\
0.814\end{array}$ \\
\hline $\begin{array}{l}\gamma \tau(\not) \\
p \text {-value }\end{array}$ & $\begin{array}{l}1.56 \\
0.015\end{array}$ & $\begin{array}{l}0.85 \\
0.470\end{array}$ & $\begin{array}{l}0.71 \\
0.688\end{array}$ & $\begin{array}{l}1.00 \\
0.275\end{array}$ & $\begin{array}{l}1.10 \\
0.180\end{array}$ & $\begin{array}{l}1.04 \\
0.231\end{array}$ & $\begin{array}{l}1.43 \\
0.034\end{array}$ & $\begin{array}{l}0.93 \\
0.352\end{array}$ & $\begin{array}{l}0.90 \\
0.392\end{array}$ & $\begin{array}{l}1.44 \\
0.031\end{array}$ \\
\hline $\begin{array}{l}\gamma \text {. Diff. } \\
p \text {-value }\end{array}$ & $\begin{array}{l}1.45 \\
0.030\end{array}$ & $\begin{array}{l}0.59 \\
0.879\end{array}$ & $\begin{array}{l}0.94 \\
0.346\end{array}$ & $\begin{array}{l}0.62 \\
0.840\end{array}$ & $\begin{array}{l}1.15 \\
0.139\end{array}$ & $\begin{array}{l}1.14 \\
0.148\end{array}$ & $\begin{array}{l}0.64 \\
0.814\end{array}$ & $\begin{array}{l}0.52 \\
0.953\end{array}$ & $\begin{array}{l}0.59 \\
0.874\end{array}$ & $\begin{array}{l}1.35 \\
0.052\end{array}$ \\
\hline
\end{tabular}




\section{Table IX}

Bootstrap percentiles for the Kolmogorov-Smirnov test of the equality of conditional and unconditional 1-day return distributions for NYSE/AMEX and NASDAQ stocks from 1962 to 1996, and for size quintiles, under the null hypothesis of equality. For each of the two sets of market data, two sample sizes, $m_{1}$ and $m_{2}$, have been chosen to span the range of frequency counts of patterns reported in Table 1. For each sample size $m_{i}$, we resample 1-day normalized returns (with replacement) to obtain a bootstrap sample of $m_{i}$ observations, compute the Kolmogorov-Smirnov test statistic (against the entire sample of 1-day normalized returns), and repeat this procedure 1,000 times. The percentiles of the asymptotic distribution are also reported for comparison.

\begin{tabular}{|c|c|c|c|c|c|c|c|c|c|c|}
\hline \multirow{2}{*}{ Percentile } & \multicolumn{5}{|c|}{ NYSE/AMEX Sample } & \multicolumn{5}{|c|}{ NASDAQ Sample } \\
\hline & $m_{1}$ & $\Delta_{m_{1}, n}$ & $m_{2}$ & $\Delta_{m_{2}, \pi}$ & $\Delta$ & $m i_{1}$ & $\Delta_{m_{1}, n}$ & $m_{2}$ & $\Delta_{m_{2}, \pi}$ & $\Delta$ \\
\hline \multicolumn{11}{|c|}{ All Stocks, 1962 to 1996} \\
\hline 0.01 & 2076 & 0.433 & 725 & 0.435 & 0.441 & 1320 & 0.430 & 414 & 0.438 & 0.441 \\
\hline 0.05 & 2076 & 0.515 & 725 & 0.535 & 0.520 & 1320 & 0.514 & 414 & 0.522 & 0.520 \\
\hline 0.10 & 2076 & 0.568 & 725 & 0.590 & 0.571 & 1320 & 0.573 & 414 & 0.566 & 0.571 \\
\hline 0.50 & 2076 & 0.827 & 725 & 0.836 & 0.828 & 1320 & 0.840 & 414 & 0.826 & 0.828 \\
\hline 0.90 & 2076 & 1.219 & 725 & 1.237 & 1.224 & 1320 & 1.244 & 414 & 1.229 & 1.224 \\
\hline 0.95 & 2076 & 1.385 & 725 & 1.395 & 1.358 & 1320 & 1.373 & 414 & 1.340 & 1.358 \\
\hline 0.99 & 2076 & 1.608 & 725 & 1.611 & 1.628 & 1320 & 1.645 & 414 & 1.600 & 1.628 \\
\hline \multicolumn{11}{|c|}{ Smallest Quintile, 1962 to 1996} \\
\hline 0.01 & 320 & 0.456 & 78 & 0.406 & 0.441 & 218 & 0.459 & 41 & 0.436 & 0.441 \\
\hline 0.05 & 320 & 0.535 & 78 & 0.502 & 0.520 & 218 & 0.533 & 41 & 0.498 & 0.520 \\
\hline 0.10 & 320 & 0.586 & 78 & 0.559 & 0.571 & 218 & 0.590 & 41 & 0.543 & 0.571 \\
\hline 0.50 & 320 & 0.848 & 78 & 0.814 & 0.828 & 218 & 0.847 & 41 & 0.801 & 0.828 \\
\hline 0.90 & 320 & 1.231 & 78 & 1.204 & 1.224 & 218 & 1.229 & 41 & 1.216 & 1.224 \\
\hline 0.95 & 320 & 1.357 & 78 & 1.330 & 1.358 & 218 & 1.381 & 41 & 1.332 & 1.358 \\
\hline 0.99 & 320 & 1.661 & 78 & 1.590 & 1.628 & 218 & 1.708 & 41 & 1.571 & 1.628 \\
\hline \multicolumn{11}{|c|}{ 2nd Quintile, 1962 to 1996} \\
\hline 0.01 & 420 & 0.445 & 146 & 0.428 & 0.441 & 305 & 0.458 & 68 & 0.426 & 0.441 \\
\hline 0.05 & 420 & 0.530 & 146 & 0.505 & 0.520 & 305 & 0.557 & 68 & 0.501 & 0.520 \\
\hline 0.10 & 420 & 0.580 & 146 & 0.553 & 0.571 & 305 & 0.610 & 68 & 0.559 & 0.571 \\
\hline 0.50 & 420 & 0.831 & 146 & 0.823 & 0.828 & 305 & 0.862 & 68 & 0.804 & 0.828 \\
\hline 0.90 & 420 & 1.197 & 146 & 1.210 & 1.224 & 305 & 1.265 & 68 & 1.210 & 1.224 \\
\hline 0.95 & 420 & 1.349 & 146 & 1.343 & 1.358 & 305 & 1.407 & 68 & 1.409 & 1.358 \\
\hline 0.99 & 420 & 1.634 & 146 & 1.626 & 1.628 & 305 & 1.686 & 68 & 1.614 & 1.628 \\
\hline \multicolumn{11}{|c|}{ 3rd Quintile, 1962 to 1996} \\
\hline 0.01 & 458 & 0.442 & 145 & 0.458 & 0.441 & 279 & 0.464 & 105 & 0.425 & 0.441 \\
\hline 0.05 & 458 & 0.516 & 145 & 0.508 & 0.520 & 279 & 0.539 & 105 & 0.525 & 0.520 \\
\hline 0.10 & 458 & 0.559 & 145 & 0.557 & 0.571 & 279 & 0.586 & 105 & 0.570 & 0.571 \\
\hline 0.50 & 458 & 0.838 & 145 & 0.835 & 0.828 & 279 & 0.832 & 105 & 0.818 & 0.828 \\
\hline 0.90 & 458 & 1.216 & 145 & 1.251 & 1.224 & 279 & 1.220 & 105 & 1.233 & 1.224 \\
\hline 0.95 & 458 & 1.406 & 145 & 1.397 & 1.358 & 279 & 1.357 & 105 & 1.355 & 1.358 \\
\hline 0.99 & 458 & 1.660 & 145 & 1.661 & 1.628 & 279 & 1.606 & 105 & 1.638 & 1.628 \\
\hline
\end{tabular}


Table IX (continued)

\begin{tabular}{|c|c|c|c|c|c|c|c|c|c|c|}
\hline \multirow{2}{*}{ Percentile } & \multicolumn{5}{|c|}{ NYSE/AMEX Sample } & \multicolumn{5}{|c|}{ NASDAQ Sample } \\
\hline & $m_{1}$ & $\Delta_{m_{1}, n}$ & $m_{2}$ & $\Delta_{m_{2}, n}$ & $\Delta$ & $m_{1}$ & $\Delta_{m_{1}, n}$ & $m_{2}$ & $\Delta_{m_{2, n}}$ & $\Delta$ \\
\hline \multicolumn{11}{|c|}{ 4th Quintile, 1962 to 1996} \\
\hline 0.01 & 424 & 0.429 & 173 & 0.418 & 0.441 & 303 & 0.454 & 92 & 0.446 & 0.441 \\
\hline 0.05 & 424 & 0.506 & 173 & 0.516 & 0.520 & 303 & 0.526 & 92 & 0.506 & 0.520 \\
\hline 0.10 & 424 & 0.552 & 173 & 0.559 & 0.571 & 303 & 0.563 & 92 & 0.554 & 0.571 \\
\hline 0.50 & 424 & 0.823 & 173 & 0.815 & 0.828 & 303 & 0.840 & 92 & 0.818 & 0.828 \\
\hline 0.90 & 424 & 1.197 & 173 & 1.183 & 1.224 & 303 & 1.217 & 92 & 1.178 & 1.224 \\
\hline 0.95 & 424 & 1.336 & 173 & 1.313 & 1.358 & 303 & 1.350 & 92 & 1.327 & 1.358 \\
\hline 0.99 & 424 & 1.664 & 173 & 1.592 & 1.628 & 303 & 1.659 & 92 & 1.606 & 1.628 \\
\hline \multicolumn{11}{|c|}{ Largest Quintile, 1962 to 1996} \\
\hline 0.01 & 561 & 0.421 & 167 & 0.425 & 0.441 & 308 & 0.441 & 108 & 0.429 & 0.441 \\
\hline 0.05 & 561 & 0.509 & 167 & 0.500 & 0.520 & 308 & 0.520 & 108 & 0.508 & 0.520 \\
\hline 0.10 & 561 & 0.557 & 167 & 0.554 & 0.571 & 308 & 0.573 & 108 & 0.558 & 0.571 \\
\hline 0.50 & 561 & 0.830 & 167 & 0.817 & 0.828 & 308 & 0.842 & 108 & 0.816 & 0.828 \\
\hline 0.90 & 561 & 1.218 & 167 & 1.202 & 1.224 & 308 & 1.231 & 108 & 1.226 & 1.224 \\
\hline 0.95 & 561 & 1.369 & 167 & 1.308 & 1.358 & 308 & 1.408 & 108 & 1.357 & 1.358 \\
\hline 0.99 & 561 & 1.565 & 167 & 1.615 & 1.628 & 308 & 1.724 & 108 & 1.630 & 1.628 \\
\hline
\end{tabular}


Table X (continued)

\begin{tabular}{|c|c|c|c|c|c|c|c|c|c|c|}
\hline \multirow{2}{*}{ Percentile } & \multicolumn{5}{|c|}{ NYSE/AMEX Sample } & \multicolumn{5}{|c|}{ NASDAQ Sample } \\
\hline & $m_{1}$ & $\Delta_{m_{1}, n}$ & $m_{2}$ & $\Delta_{m_{2, n}}$ & $\Delta$ & $m_{1}$ & $\Delta_{m_{1}, n}$ & $m_{2}$ & $\Delta_{m_{2}, n}$ & $\Delta$ \\
\hline \multicolumn{11}{|c|}{ All Stocks, 1982 to 1986} \\
\hline 0.01 & 313 & 0.462 & 106 & 0.437 & 0.441 & 120 & 0.448 & 44 & 0.417 & 0.441 \\
\hline 0.05 & 313 & 0.542 & 106 & 0.506 & 0.520 & 120 & 0.514 & 44 & 0.499 & 0.520 \\
\hline 0.10 & 313 & 0.585 & 106 & 0.559 & 0.571 & 120 & 0.579 & 44 & 0.555 & 0.571 \\
\hline 0.50 & 313 & 0.844 & 106 & 0.819 & 0.828 & 120 & 0.825 & 44 & 0.802 & 0.828 \\
\hline 0.90 & 313 & 1.266 & 106 & 1.220 & 1.224 & 120 & 1.253 & 44 & 1.197 & 1.224 \\
\hline 0.95 & 313 & 1.397 & 106 & 1.369 & 1.358 & 120 & 1.366 & 44 & 1.337 & 1.358 \\
\hline 0.99 & 313 & 1.727 & 106 & 1.615 & 1.628 & 120 & 1.692 & 44 & 1.631 & 1.628 \\
\hline \multicolumn{11}{|c|}{ All Stocks, 1987 to 1991} \\
\hline 0.01 & 287 & 0.443 & 98 & 0.449 & 0.441 & 312 & 0.455 & 50 & 0.432 & 0.441 \\
\hline 0.05 & 287 & 0.513 & 98 & 0.522 & 0.520 & 312 & 0.542 & 50 & 0.517 & 0.520 \\
\hline 0.10 & 287 & 0.565 & 98 & 0.566 & 0.571 & 312 & 0.610 & 50 & 0.563 & 0.571 \\
\hline 0.50 & 287 & 0.837 & 98 & 0.813 & 0.828 & 312 & 0.878 & 50 & 0.814 & 0.828 \\
\hline 0.90 & 287 & 1.200 & 98 & 1.217 & 1.224 & 312 & 1.319 & 50 & 1.216 & 1.224 \\
\hline 0.95 & 287 & 1.336 & 98 & 1.348 & 1.358 & 312 & 1.457 & 50 & 1.323 & 1.358 \\
\hline 0.99 & 287 & 1.626 & 98 & 1.563 & 1.628 & 312 & 1.701 & 50 & 1.648 & 1.628 \\
\hline \multicolumn{11}{|c|}{ All Stocks, 1992 to 1996} \\
\hline 0.01 & 389 & 0.438 & 102 & 0.432 & 0.441 & 361 & 0.447 & 87 & 0.428 & 0.441 \\
\hline 0.05 & 389 & 0.522 & 102 & 0.506 & 0.520 & 361 & 0.518 & 87 & 0.492 & 0.520 \\
\hline 0.10 & 389 & 0.567 & 102 & 0.558 & 0.571 & 361 & 0.559 & 87 & 0.550 & 0.571 \\
\hline 0.50 & 389 & 0.824 & 102 & 0.818 & 0.828 & 361 & 0.817 & 87 & 0.799 & 0.828 \\
\hline 0.90 & 389 & 1.220 & 102 & 1.213 & 1.224 & 361 & 1.226 & 87 & 1.216 & 1.224 \\
\hline 0.95 & 389 & 1.321 & 102 & 1.310 & 1.358 & 361 & 1.353 & 87 & 1.341 & 1.358 \\
\hline 0.99 & 389 & 1.580 & 102 & 1.616 & 1.628 & 361 & 1.617 & 87 & 1.572 & 1.628 \\
\hline
\end{tabular}

